VILNIAUS GEDIMINO TECHNIKOS UNIVERSITETAS

Artūras VENSKUS

\title{
PRISITAIKANČIŲ KONSTRUKCIJŲ OPTIMIZAVIMAS. SAZSAJOS SU PROJEKTAVIMO STANDARTAIS
}

DAKTARO DISERTACIJA

TECHNOLOGIJOS MOKSLAI, STATYBOS INŽINERIJA (02T) 
Disertacija rengta 2004-2011 metais Vilniaus Gedimino technikos universitete. Disertacija ginama eksternu.

\section{Mokslinis konsultantas}

prof. habil. dr. Juozas ATKOČIŪNAS (Vilniaus Gedimino technikos universitetas, statybos inžinerija - 02T).

Vilniaus Gedimino technikos universiteto Statybos inžinerijos mokslo krypties disertacijos gynimo taryba:

\section{Pirmininkas}

prof. habil. dr. Gintaris KAKLAUSKAS (Vilniaus Gedimino technikos universitetas, statybos inžinerija - 02T).

\section{Nariai:}

prof. dr. Donatas ČYGAS (Vilniaus Gedimino technikos universitetas, statybos inžinerija - 02T),

prof. habil. dr. Audronis Kazimieras KVEDARAS (Vilniaus Gedimino technikos universitetas, statybos inžinerija - 02T),

prof. habil. dr. Vytautas STANKEVIČIUS (Kauno technologijos universitetas, statybos inžinerija - 02T),

prof. habil. dr. Vitauts TAMUZS (Latvijos universiteto Polimeru mechanikos institutas, medžiagų inžinerija - 08T).

Disertacija bus ginama viešame Statybos inžinerijos mokslo krypties disertacijos gynimo tarybos posédyje 2011 m. birželio 14 d. 10 val. Vilniaus Gedimino technikos universiteto senato posėdžių salëje.

Adresas: Saulètekio al. 11, LT-10223 Vilnius, Lietuva.

Tel.: (8 5) 274 4956; faksas (8 5) 270 0112; el. paštas doktor@vgtu.lt

Pranešimai apie numatomą ginti disertaciją išsiusti $2011 \mathrm{~m}$. gegužès $13 \mathrm{~d}$.

Disertaciją galima peržiūrèti interneto svetainèje http://dspace.vgtu.lt ir Vilniaus Gedimino technikos universiteto bibliotekoje (Sauletekio al. 14, LT-10223 Vilnius, Lietuva).

VGTU leidyklos TECHNIKA 1887-M mokslo literatūros knyga

ISBN 978-9955-28-863-3

(C) VGTU leidykla TECHNIKA, 2011

(C) Artūras Venskus, 2011

venartas@yahoo.fr 
VILNIUS GEDIMINAS TECHNICAL UNIVERSITY

Artūras VENSKUS

OPTMIZATION METHODS

OF SHAKEDOWN STRUCTURES

IN THE CONTEXT OF STANDARDS

DOCTORAL DISSERTATION

TECHNOLOGICAL SCIENCES,

CIVIL ENGINEERING (02T) 
Doctoral dissertation was prepared at Vilnius Gediminas Technical University in 2004-2011.

The dissertation is defended as an external work.

\section{Scientific Consultant}

Prof Dr Habil Juozas ATKOČIŪNAS (Vilnius Gediminas Technical University, Civil Engineering - 02T).

The Dissertation Defence Council of Scientific Field of Civil Engineering of Vilnius Gediminas Technical University:

\section{Chairman}

Prof Dr Habil Gintaris KAKLAUSKAS (Vilnius Gediminas Technical University, Civil Engineering - 02T).

\section{Members:}

Prof Dr Donatas ČYGAS (Vilnius Gediminas Technical University, Civil Engineering - 02T),

Prof Dr Habil Audronis Kazimieras KVEDARAS (Vilnius Gediminas Technical University, Civil Engineering - 02T),

Prof Dr Habil Vytautas STANKEVIČIUS (Kaunas University of Technology, Civil Engineering - 02T),

Prof Dr Habil Vitauts TAMUZS (University of Latvia, Institute of Polymer Mechanics, Materials Engineering - 08T).

The dissertation will be defended at the public meeting of the Dissertation Defence Council of Civil Engineering in the Senate Hall of Vilnius Gediminas Technical University at 10 a. m. on 14 June 2011.

Address: Sauletekio al. 11, LT-10223 Vilnius, Lithuania.

Tel.: +370 5274 4956; fax +370 5270 0112; e-mail: doktor@vgtu.lt

A notification on the intend defending of the dissertation was send on 13 May 2011.

A copy of the doctoral dissertation is available for review at the Internet website http://dspace.vgtu.lt and at the Library of Vilnius Gediminas Technical University (Sauletekio al. 14, LT-10223 Vilnius, Lithuania). 


\section{Reziumè}

Disertaciniame darbe išplètota vieninga tamprių-plastinių prisitaikančių sistemų optimizavimo su stiprumo, standumo ir klumpamosios galios salygomis, taikant ekstreminius energinius principus, matematinio programavimo teorija, šiuolaikines kompiuterines technologijas ir sąsajas su projektavimo standartais, metodika. Darbe parodyta, kad prisitaikomumo teorija yra bendriausias metodinis įrankis skirtas statybinių konstrukcijų skaičiavimui nuo įvairių apkrovų, igalinantis išvengti detalios apkrovimo istorijos nagrinejjimo.

Disertaciją sudaro įvadas, penkeri skyriai, rezultatu apibendrinimas, naudotos literatūros ir autoriaus publikacijų disertacijos tema sąrašai ir keturi priedai.

Ivadiniame skyriuje aptariama tiriamoji problema, darbo aktualumas, aprašomas tyrimų objektas, formuluojamas darbo tikslas bei uždaviniai, aprašoma tyrimų metodika, darbo mokslinis naujumas, darbo rezultatu praktinè reikšmé, ginamieji teiginiai. Ivado pabaigoje pristatomos disertacijos tema autoriaus paskelbtos publikacijos ir pranešimų konferencijose sąrašas bei disertacijos struktūra.

Pirmasis skyrius skirtas literatūros apžvalgai. Jame atlikta prisitaikančių konstrukcijų optimizavimo metodų apžvalga, išryškinta būtinybė pasitelkti sąsajas tarp teorinių optimizavimo metodų ir projektavimo standartų.

Antrajame skyriuje aptariama konstrukcijų diskretizacija, sudaryti patobulinti projektinio ir patikrinamojo uždavinių matematiniai modeliai.

Trečiajame skyriuje parodyta sąsaja tarp statybos inžinerijoje naudojamų apkrovų derinių ir kartotinès-kintamosios apkrovos. Pasiūlyta metodika leidžianti integruotai projektuoti prisitaikančias konstrukcijas ivvertinant stipruma, standumą ir klumpamaja galią.

Ketvirtajame skyriuje aprašomos autoriaus sukurtos netiesinio programavimo programos, aptariama jų valdymo specifika.

Penktas skyrius skirtas dvimatės plokštès patikrinamajam uždaviniui. Pasiūlytas naujas sprendimo algoritmas kombinuojantis Mizeso ir Treska takumo sąlygas.

Disertacijos tema paskelbta 12 straipsnių: šeši - leidiniuose itrauktuose i Thomson ISI sąraša; vienas konferencijų medžiagoje, referuotoje Thomson ISI duomenų bazejje; vienas - recenzuojamoje užsienio tarptautinès konferencijos medžiagoje; vienas - recenzuojamame užsienio mokslo leidinyje; vienas recenzuojamoje Lietuvos tarptautinès konferencijos medžiagoje; du - nerecenzuojamoje Lietuvos konferencijos medžiagoje. Disertacijos tema perskaityti 8 pranešimai Lietuvos bei kitų šalių konferencijose. 


\section{Abstract}

The optimization methodology of shakedow structures evaluating strength, stiffness and stability constraints and unifying extremum energy principles, mathematical programming theory, stat-of-the-art computer technologies and design standards was developed in the dissertation. There are shown in the work that shakedown theory is a generalized tool for calculation of civil engineering structures under different loading conditions that avoid detailed investigation of loading history.

The dissertation consists of six parts including Introduction, 5 chapters, Conclusions, References and 4 Annexes.

The introduction reveals the investigated problem, importance of the thesis and the object of research and describes the purpose and tasks of the paper, research methodology, scientific novelty, the practical significance of results examined in the paper and defended statements. The introduction ends in presenting the author's publications on the subject of the defended dissertation, offering the material of made presentations in conferences and defining the structure of the dissertation.

Chapter 1 revises used literature. The optimization methods of shakedown structures are reviewed and a demand of linkage between theoretical optimization methods and standards is highlighted.

Chapter 2 describes the discretization of structures, the mathematical models for improved design and check problems was created.

In the Chapter 3 the equivalence between load combinations of civil engineering standards and repeated variable load is shown. The methodology enabling integrated design of shakedown structures, with included strength, stiffness and stability constraints, is proposed.

Chapter 4 describes authors created nonlinear programming software and its usage peculiarity.

Chapter 5 dedicated to plate check problem. A new algorithm combining von Mises and Tresca yield is proposed.

12 articles focusing on the subject of the discussed dissertation are published: six articles - in the Thomson ISI register, one article - in conference material in Thomson ISI data base, one article - in material reviewed during international conference, one article in the reviewed international edition; one article during an international conference in Lithuania, two articles during a national conference. 8 presentations on the subject have been given in conferences at national and international level. 


\section{Žymëjimai}

\section{Pagrindiniai simboliai}

\section{Matricos}

$\boldsymbol{A}$ - pusiausvyros lygčių koeficientų matrica;

$\boldsymbol{D}$ - konstrukcijos pasiduodamumo matrica;

$\boldsymbol{G}$ - liekamujų iražžu influentinè matrica;

$\boldsymbol{H}$ - liekamuju poslinkių influentinè matrica;

$\boldsymbol{K}$ - konstrukcijos globalinè standumo matrica;

$\boldsymbol{\alpha}$ - įrąžų infliuentinè matrica;

$\boldsymbol{\beta}$ - poslinkių infliuentinè matrica;

$\boldsymbol{\Phi}$ - takumo sąlygų matrica.

\section{Vektoriai}

$\boldsymbol{F}_{\text {sup }}, \boldsymbol{F}_{\text {inf }}-$ jègų kitimo apatinių ir viršutinių ribų reikšmių vektoriai;

$\boldsymbol{M}_{0}$ - ribinių momentų vektorius;

$N_{0}$ - ribinių ašinių jègų vektorius;

$\boldsymbol{S}$ - įrąžu vektorius;

$\boldsymbol{S}_{r}-$ liekamujų irą̌žų vektorius;

$\boldsymbol{S}_{0}$ - ribinių irąžų vektorius; 
$\boldsymbol{u}$ - poslinkių vektorius;

$\boldsymbol{u}_{r}-$ liekamuju poslinkių vektorius;

$\lambda$ - Lagranžo daugiklių vektorius, plastinių daugiklių vektorius;

$\boldsymbol{\Theta}$ - deformacijų vektorius;

$\boldsymbol{\Theta}_{r}$ - liekamujų deformacijų vektorius;

$\boldsymbol{\Theta}_{p}-$ plastinių deformacijų vektorius.

\section{Skaliarai}

$E$ - medžiagos tamprumo modulis;

$V$ - kūno tūris.

\section{Indeksai}

$e$ - tamprusis;

$i$ - kintamas indeksas;

$j$ - tampraus hodografo viršūnè, jų aibè $J$;

$k$ - baigtinio elemento indeksas;

$p$ - plastinis;

$r$ - liekamasis.

\section{Santrumpos}

KKA - kartotinė-kintamoji apkrova;

EN1993 - Europos plieninių konstrukcijų projektavimo standartas;

NEN6771 - Olandų plieninių konstrukcijų projektavimo standartas. 


\section{Turinys}

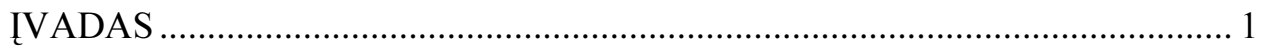

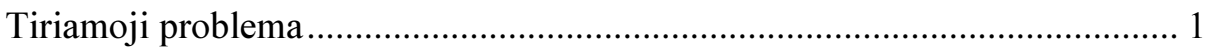

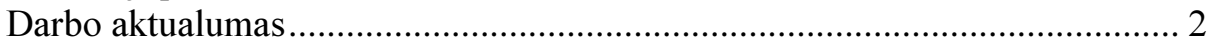

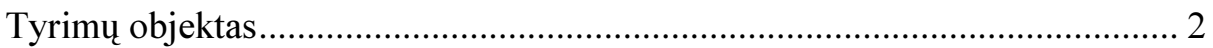

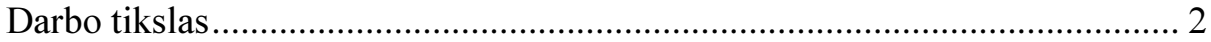

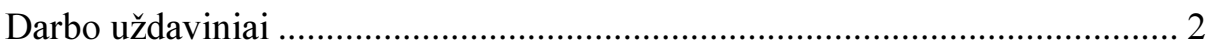

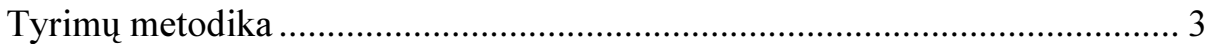

Darbo mokslinis naujumas ir jo reikšmè ........................................................ 3

Darbo rezultatų praktinè reikšmė .............................................................. 4

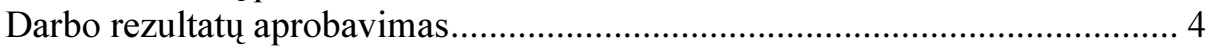

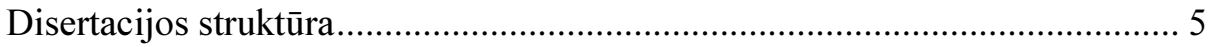

1. PRISITAIKOMUMO TEORIJOS ANALIZE் …........................................... 7

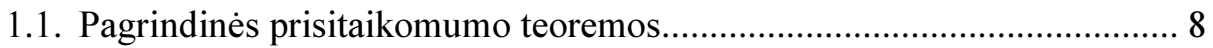

1.1.1. Melano statinè prisitaikomumo teorema........................................ 8

1.1.2. Koiterio kinematinè prisitaikomumo teorema …............................ 8

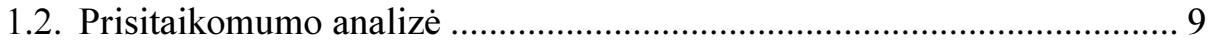

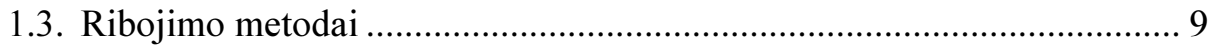

1.4. Optimalus projektavimas prisitaikomumo sąlygomis............................ 10

1.5. Dualumas ir matematinis programavimas ........................................... 11

1.6. Pirmojo skyriaus išvados ir disertacijos uždavinių formulavimas.......... 12 


\section{PATOBULINTI PRISITAIKANČIUU KONSTRUKCIJŲ}

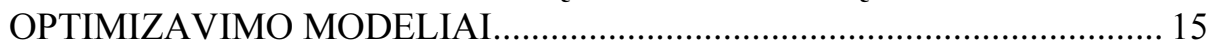

2.1. Diskretinès sistemos įrąžos ir deformacijos.......................................... 16

2.2. Tampriujų įrąžų hodografas................................................................... 18

2.3. Kartotinès-kintamosios apkrovos takumo sąlygos ............................... 19

2.4. Prisitaikiusios sistemos geometrinès lygtys............................................ 20

2.5. Projektinio uždavinio matematinis modelis........................................ 20

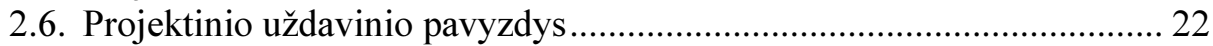

2.7. Patikrinamojo uždavinio matematinis modelis..................................... 26

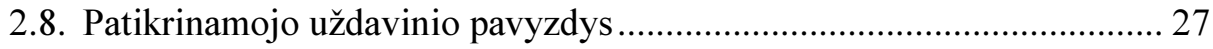

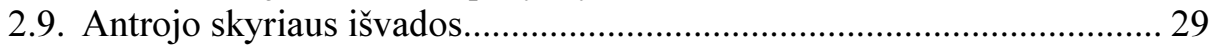

\section{PRISITAIKANČIŲ KONSTRUKCIJŲ OPTIMIZAVIMAS}

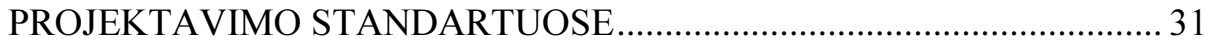

3.1. Apkrovų deriniai - kartotinės-kintamosios apkrovos viršūnės............... 32

3.2. Judama apkrova - atskiras kartotinès-kintamosios apkrovos atvejis...... 35

3.3. Vienkarte apkrova - atskiras kartotinès-kintamosios apkrovos atvejis .. 37

3.4. Stiprumo, standumo ir klumpamosios galios ivertinimas

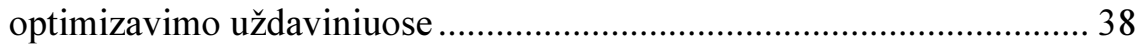

3.4.1. Optimizavimo uždavinių matematiniai modeliai ........................ 38

3.4.2. Klumpamosios galios skaičiavimas pagal EN1993 projektavimo standartą ................................................................ 39

3.4.3. Klumpamosios galios skaičiavimas pagal NEN6771

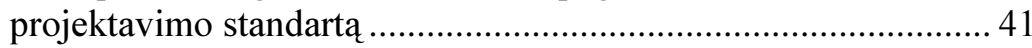

3.4.4. Klumpamosios galios įvertinimo algoritmas optimizavimo

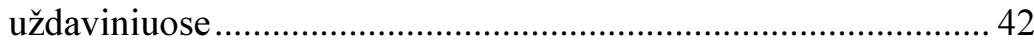

3.4.5. Optimizavimo programų ir MatrixFrame integruotas

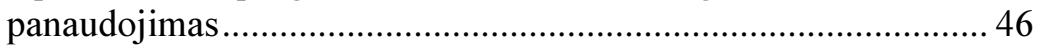

3.4.6. Rèmo projektinio uždavinio pavyzdys ...................................... 51

3.4.7. Rėmo apkrovos optimizavimo uždavinio pavyzdys .................... 55

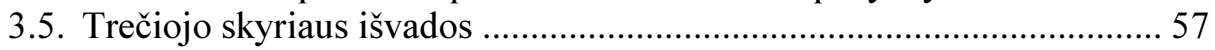

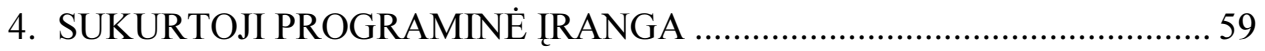

4.1. Rozeno projektuojamujų gradientų algoritmas..................................... 59

4.2. Rozeno algoritmo valdymo specifika ir patirtis.................................... 61

4.3. Pradinių duomenų formavimas programai M0opt 1 ................................ 65

4.4. Pradinių duomenų formavimas programai MaxFopt 1 ......................... 67

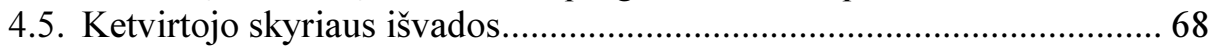




\section{PRISITAIKANČIU TAMPRIŲJŲ-PLASTINIŲ SIMETRINIŲ} PLOKŠČIU APKROVOS OPTIMIZAVIMAS

5.1. Diskretinès plokštės i̇ą̌žos ir deformacijos ............................................ 69

5.2. Pagrindinès priklausomybès ciklinès apkrovos atveju ......................... 74

5.3. Analizès uždavinio matematiniai modeliai........................................ 75

5.4. Liekamujų ilinkių ir momentų infliuentinès matricos ........................... 76

5.5. Kartotinès-kintamosios apkrovos optimizavimo algoritmas ................. 77

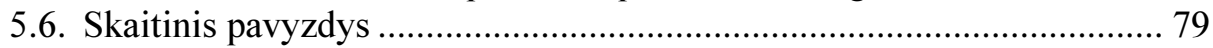

5.7. Penktojo skyriaus išvados.............................................................. 81

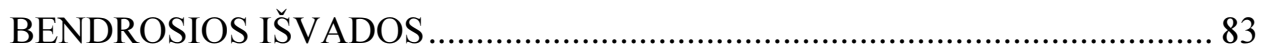

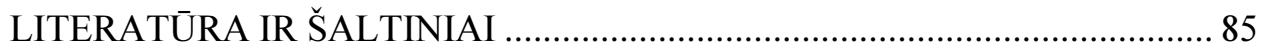

AUTORIAUS PUBLIKACIJŲ DISERTACIJOS TEMA SAZRAŠAS............... 93

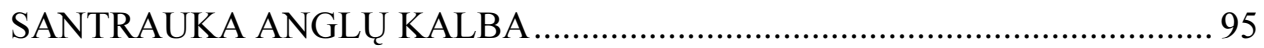

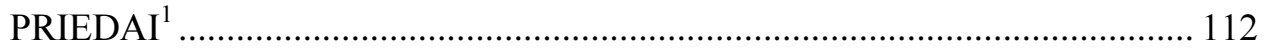

A priedas. M0opt1 programos gradientų skaičiavimo paprogramės ........... 113

A1. Tikslo funkcijos skaičiavimo paprogramè ................................ 113

A2. Tikslo funkcijos gradiento skaičiavimo paprogramė .................. 114

A3. Apribojimų ir jų gradientų skaičiavimo paprogramė .................. 114

B priedas. MaxFopt 1 programos gradientų skaičiavimo paprogramės ....... 117

B1. Tikslo funkcijos skaičiavimo paprogramè.................................. 117

B2. Tikslo funkcijos gradiento skaičiavimo paprogramè................... 118

B3. Apribojimų ir jų gradientų skaičiavimo paprogramė................... 120

$\mathrm{C}$ priedas. Publikacijų bendraautorių sutikimai teikti publikacijas

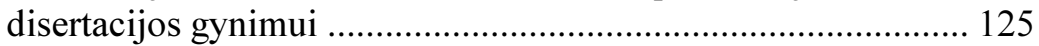

D priedas. Autoriaus publikacijų disertacijos tema kopijos ..................... 132

\footnotetext{
${ }^{1}$ Priedai pateikti pridètoje elektronineje laikmenoje
} 



\section{Contents}

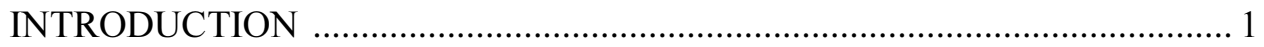

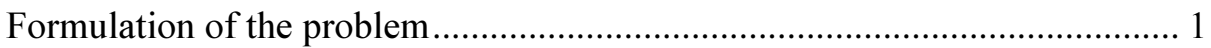

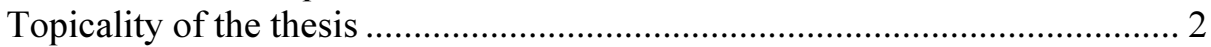

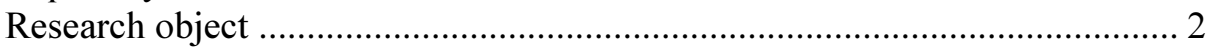

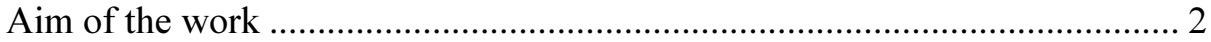

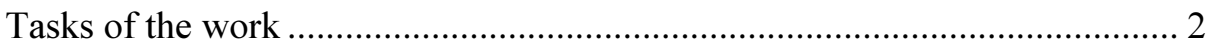

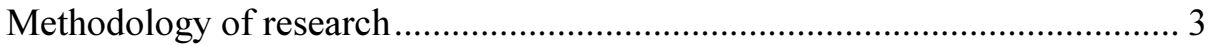

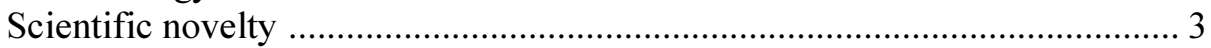

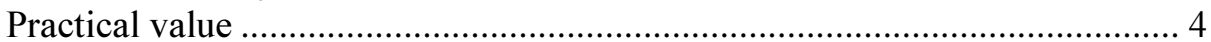

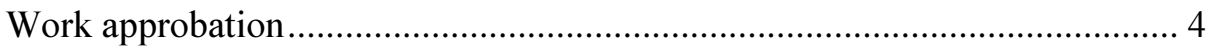

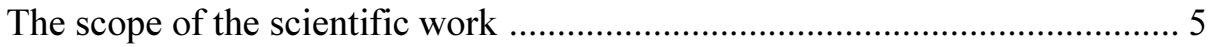

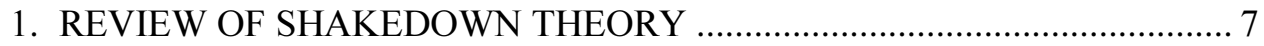

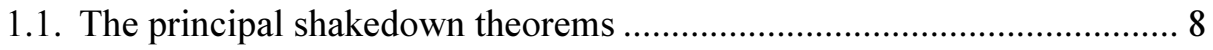

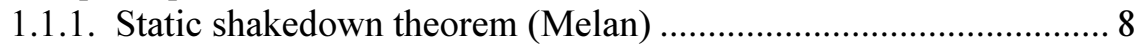

1.1.2. Kinematic shakedown theorem (Koiter) ....................................... 8

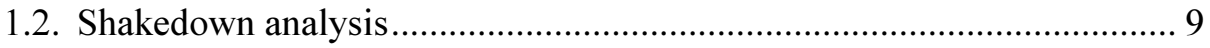

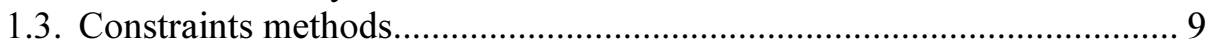

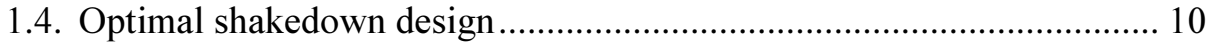

1.5. Duality and mathematical programming ............................................. 11

1.6. Conclusions of Chapter 1 and formulating tasks for the dissertation ..... 12 
2. IMPROVED OPTIMIZATION MODELS FOR SHAKEDOWN

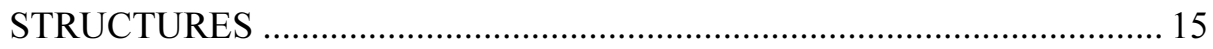

2.1. Internal forces and strains of discretised system................................... 16

2.2. Locus of elastic forces ...................................................................... 18

2.3. Yield conditions of repeated variable load ........................................... 19

2.4. Geometrical equations of shakedown system ...................................... 20

2.5. Mathematical model of design problem ............................................. 20

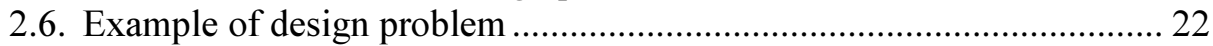

2.7. Mathematical model of check problem …........................................... 26

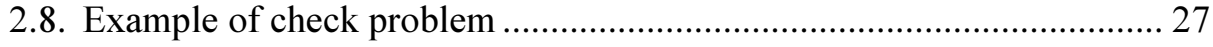

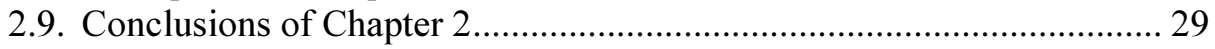

3. OPTIMIZATION OF SHAKEDOWN STRUCTURES

IN THE CONTEXT OF STANDARDS ……............................................... 31

3.1. Load combinations - repeated variable load bounds ............................ 32

3.2. Moving load - separate case of repeated variable load ........................ 35

3.3. Monotonically increasing loading - separate case of repeated

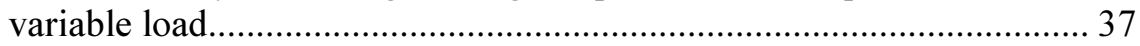

3.4. Strength, stiffness and stability evaluation in optimization problems .... 38

3.4.1. Mathematical models of optimization problems .......................... 38

3.4.2. Stability calculation according to EN1993 standard ..................... 39

3.4.3. Stability calculation according to NEN6771 standard ................. 41

3.4.4. Stability evaluation algorithm for optimization problems............ 42

3.4.5. Integrated application of MatrixFrame and optimization software ................................................................ 46

3.4.6. Example of frame design problem ………............................... 51

3.4.7. Example of frame check problem................................................ 55

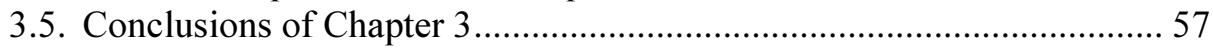

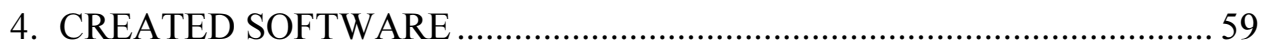

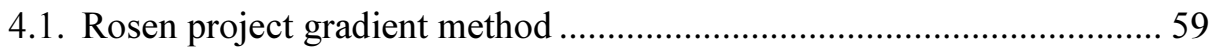

4.2. Rosen algorithm particularities and calculation experience ................... 61

4.3. Initial data preparation for software module M0opt 1 ...........................6 65

4.4. Initial data preparation for software module MaxFopt 1 ........................ 67

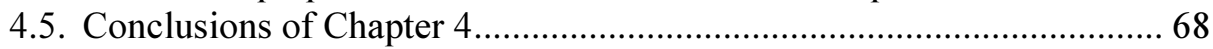

5. LOAD OPTIMIZATION OF ELASTIC-PLASTIC AXISYMMETRIC

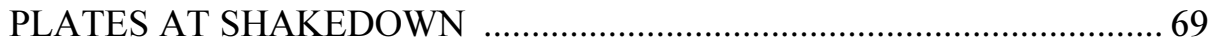

5.1. Internal forces and strains of discretised plate........................................ 69

5.2. The main dependencies in the case of cyclic loading ............................ 74

5.3. The mathematical models of the analysis problem................................ 75 
5.4. The influence matrixes of the residual displacements and

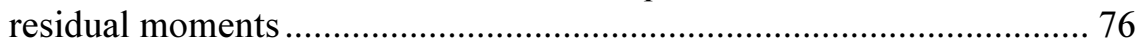

5.5. The algorithm of repeated variable load optimization .......................... 77

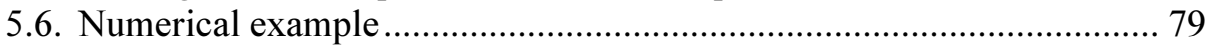

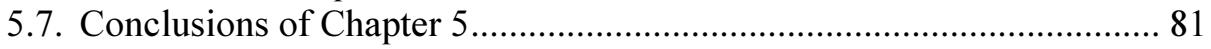

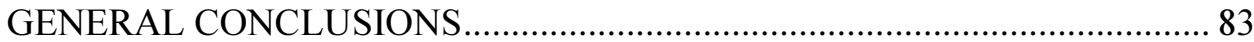

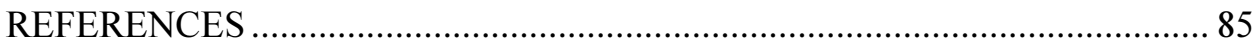

LIST OF PUBLICATIONS BY THE AUTHOR ON THE TOPIC OF

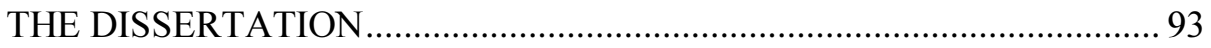

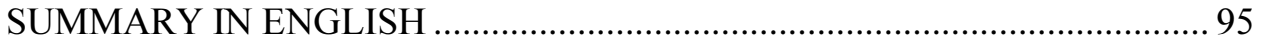

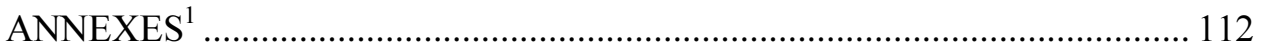

Annex A. Gradient calculation subroutines for software M0opt1 ............. 113

A1. Objective function calculation subroutine .................................. 113

A2. Objective function gradient calculation subroutine..................... 114

A3. Constraints and its gradients calculation subroutine ................. 114

Annex B. Gradient calculation subroutines for software MaxFopt1 .......... 117

B1. Objective function calculation subroutine ................................. 117

B2. Objective function gradient calculation subroutine.................... 118

B3. Constraints and its gradients calculation subroutine ................. 120

Annex C. The coauthors agreements to present publications for the dissertation defence ........................................................... 125

Annex D. Copies of scientific publications by the author on

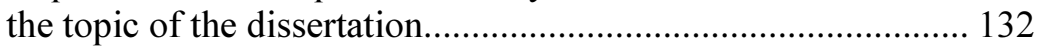

${ }^{1}$ The annexes are supplied in the enclosed compact disc 



\section{Ivadas}

\section{Tiriamoji problema}

Konstrukcijų, patiriančių kintamus kartotinius mechaninius ir kitus poveikius, stiprumo, standumo ir klumpamosios galios problemų sprendimas glaudžiai susietas su prisitaikomumo teorija. Šią teoriją visapusiškai naudoti dar ir dabar trukdo nepakankama matematine kai kurių uždavinių formalizacija ir nenuoseklus matematinio programavimo teorijos ir jos metodų panaudojimas.

Prisitaikančių konstrukcijų optimizavimo uždavinius spręsti sudètinga dar ir todèl, kad disipacinių sistemų ịtempių ir deformacijų būvis priklauso nuo apkrovimo istorijos. Šie sunkūs optimizavimo uždaviniai gali būti sprendžiami panaudojant ekstreminius energetinius principus ir matematinio programavimo teoriją.

Taigi disertaciniame darbe siekiama sukurti vieningą tamprių-plastinių prisitaikančiu sistemų optimizavimo su standumo ir klumpamosios galios salygomis, taikant ekstreminius energinius principus, matematinio programavimo teorija, skaitinius metodus ir šiuolaikines kompiuterines technologijas, metodiką. 


\section{Darbo aktualumas}

Prisitaikančių konstrukcijų optimalaus projektavimo aspektai, i̇vertinant stiprumo ir standumo sąlygas, išsamiai nagrinèti mokslinèje literatūroje. Tuo tarpu tampriuju plastinių rèmų optimizavimo uždaviniuose klumpamosios galios sąlygu ịvertinimas, kai apkrova kartotinè-kintamoji, ir dabartiniu metu lieka aktualia moksline problema. Pavyzdžiui, pagal EN1993 yra leidžiama projektuoti tampriuosius plastinius rèmus, tačiau čia nepilnai detalizuota metodika bei algoritmai prisitaikančių konstrukcijų stabilumo įvertinimui. Tai sąlygojo ir šios disertacijos mokslinių tyrimų krypties ir metodų pasirinkima, būtent, prisitaikančių konstrukcijų optimizavimo metodai projektavimo standartų kontekste.

\section{Tyrimų objektas}

Tampriai plastinių prisitaikančių statybinių konstrukcijų nauji optimizavimo teoriniai sprendimai ir metodai bei jų tobulinimas ir su tuo susijusių ekstreminiu energiniu principų, matematinio programavimo teorijos bei šiuolaikinių kompiuterinių technologijų plètotė ir taikymas projektavimo standartų kontekste.

\section{Darbo tikslas}

1. Patobulinti esamus prisitaikančių konstrukcijų optimizavimo matematinius modelius ivvertinančius stiprumą ir standuma, sukurti naują optimizavimo metodiką ivertinančią ir klumpamają galią (ekscentrini gniuždyma).

2. Integruoti sukurtą programinę irangą $i$ kompiuterinį paketą MatrixFrame ir parodyti praktinių uždavinių sprendimo galimybę pritaikant egzistuojančius projektavimo standartus.

3. Atlikti prisitaikančios konstrukcijos integruotą optimizavimą pagal projektavimo standartus ivertinant stiprumo, standumo ir klumpamosios galios sąlygas.

\section{Darbo uždaviniai}

Darbo tikslui pasiekti darbe reikia spręsti šiuos uždavinius: 
1. Sukurti prisitaikančių konstrukcijų tikrinamojo ir projektinio optimizavimo uždavinių patikslintus matematinius modelius, i standumo apribojimus jjungiant suminius (tamprius ir liekamuosius) poslinkius.

2. Skaitinejje analizejje atsisakyti skerspjūvių idealizacijos, įvesti profiliuočių realius skerspjūvio parametrus.

3. Sukurti programinę iranga prisitaikančių konstrukcijų analizei ir optimizavimui.

4. Atlikti skaičiavimus, iliustruojančius prisitaikančių strypinių konstrukcijų optimizavimą.

5. Sukurti metodika, leidžiančią autoriaus programinès irangos apskaičiuotus plastinio būvio kintamuosius (liekamąsias įražas ir liekamuosius poslinkius) integruoti $i$ kompiuterinio paketo MatrixFrame (arba analogiškos programos) atliekamą konstrukcijos analizės procesą.

6. Sukurti KKA ir projektavimo standartų sąsajas.

\section{Tyrimų metodika}

Pasitelkiami ekstreminiai energiniai deformuojamo kūno mechanikos principai ir matematinio programavimo teorija. Optimizavimo uždavinių diskretiniai matematiniai modeliai sudaromi pusiausvirujų baigtinių elementų metodu. Tyrimai atlikti ir skaitinių eksperimentų rezultatai gauti, laikantis mažų poslinkių prielaidos. Tyrimai pagrịsti autoriaus ilgamete UAB Matrix Software Baltic inžinieriaus-programuotojo patirtimi kuriant ir tobulinant komercinę konstrukcijų analizès ir projektavimo programą MatrixFrame.

\section{Darbo mokslinis naujumas ir jo reikšmè}

Rengiant disertaciją buvo gauti šie statybos inžinerijos mokslui nauji rezultatai:

1. Atskleistos matematinio programavimo, plačiai paplitusio ekstreminių uždavinių sprendimo metodo, ir ekstreminių energinių principu sąsajų teikiamos naujos galimybès, formuluojant prisitaikomumo teorijos analizès ir optimizavimo uždavinius ir juos skaitiškai sprendžiant.

2. Sudaryti nauji prisitaikančių sistemų tikrinamojo ir projektinio optimizavimo netiesinių uždavinių matematiniai modeliai su užtikrinančiomis prisitaikomumą ir standumo bei klumpamosios galios sąlygomis-apribojimais. 
3. Skaitinè analizè grindžiama I tipo skerspjūvio profiliuočių panaudojimu.

4. Realizuota prisitaikančių strypinių konstrukcijų optimizavimo metodika: patobulinti rèmų atsižvelgiant i stiprumo, standumo ir klumpamosios galios (EN1993 ir NEN6771) sąlygas, uždavinių netiesiniai matematiniai modeliai, sprendimo algoritmai, atlikti skaitiniai eksperimentai.

5. Sukurtas optimizavimo metodikos (autoriaus sukurtos programinès irangos) integracijos principas į pramoninę programą (MatrixFrame).

6. Pasiūlyta metodika leidžianti dvimačio uždavinio (plokštès) optimizavimo uždavinyje panaudoti Treska ir Mizeso takumo sąlygas, užtikrinančias efektyvesni ir tikslesnį sprendinị.

\section{Darbo rezultatų praktinè reikšmè}

Sukurtieji nauji prisitaikančių konstrukcijų optimizavimo metodai ir matematiniai modeliai ivertinantys stiprumo, standumo ir klumpamosios galios salygas gali būti naudojami konstrukcijų optimizavimui atsižvelgiant i projektavimo standartus. Sukurta programinè ịranga prisitaikančių konstrukcijų optimizavimo uždaviniams spręsti.

\section{Darbo rezultatu aprobavimas}

Disertacijos tema perskaityti 8 pranešimai Lietuvos bei kitų šalių konferencijose. Disertacijos tema paskelbta 12 straipsnių: šeši - leidiniuose įtrauktuose i Thomson ISI sąrašą (Atkočiūnas et al. 2007a; Atkočiūnas et al. 2007b; Atkočiūnas et al. 2008a; Atkočiūnas ir Venskus 2011; Kalanta et al. 2009; Venskus et al. 2010); vienas konferencijų medžiagoje, referuotoje Thomson ISI duomenų bazèje (Kalanta et al. 2007d); vienas - recenzuojamoje užsienio tarptautinès konferencijos medžiagoje (Atkočiūnas ir Venskus 2008b ); vienas - recenzuojamame užsienio mokslo leidinyje (Atkočiūnas et al. 2007c); vienas - recenzuojamoje Lietuvos tarptautinès konferencijos medžiagoje (Kalanta et al. 2007e); du - nerecenzuojamoje Lietuvos konferencijos medžiagoje (Venskus ir Atkočiūnas 2005, 2006).

Disertacijoje atliktų tyrimų rezultatai buvo paskelbti šiose mokslinėse konferencijose:

- Tarptautineje konferencijoje „Stability and Ductility of Structures”. Baltic Session of the International Colloquium sacred to the memory of the 
Millennium of the name of Lithuania mentioned for the first time in Saxon Quedlinburg annals, 2009 m., Vilniuje;

- Tarptautineje konferencijoje „Ninth International Conference on Computational Structures Technology", 2008 m., Atenuose (Graikija);

- XVI-ajame Lietuvos skaičiuojamosios mechanikos asociacijos seminare, 2008 m., Vilniuje;

- Tarptautineje konferencijoje ,Modern building materials, structures and techniques", 2007 m., Vilniuje;

- Tarptautineje konferencijoje "Strength, durability and stability of materials and structures. SDSMS'04“, 2007 m., Palangoje;

- XIV Lietuvos skaičiuojamosios mechanikos asociacijos konferencijoje. 2006 m., Vilniuje;

- Jaunujų mokslininkų konferencijoje „Mokslas - Lietuvos ateitis“ 2006 m., Vilniuje;

- Jaunujų mokslininkų konferencijoje „Lietuva be mokslo - Lietuva be

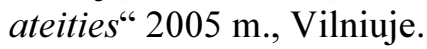

\section{Disertacijos struktūra}

Disertaciją sudaro ivvadas, penki skyriai ir išvados. Taip pat yra keturi priedai.

Darbo apimtis 94 puslapiai, neskaitant prieduc, tekste panaudotos 125 numeruotos formulès, 27 paveikslai ir 7 lentelès. Rašant disertaciją buvo panaudoti 122 literatūros šaltiniai. 



\section{Prisitaikomumo teorijos analizè}

Daugelyje inžinerinių situacijų statybinès konstrukcijos patiria toki apkrovų poveiki, kai tiksli apkrovimo istorija nežinoma arba egzistuoja žymūs apkrovos ciklinès prigimties požymiai. Todèl, esant tokiems poveikiams, praktinè svarba metodų, ivertinančių konstrukcijų elgsena, yra akivaizdi. Šiuo požiūriu prisitaikomumo teorijos taikymas tampriosioms plastinėms konstrukcijoms, veikiamoms KKA istorijos, dažnai yra būtinas reikalavimas. Konstrukcijos, veikiamos KKA, gali netekti laikomosios galios dèl mainiojo plastiškumo, prieaugiminio suirimo arba dèl staigaus plastinio suirimo. Tačiau bet kokia suirimo požiūriu saugi apkrovimo istorija gali sukelti pradinèse apkrovimo stadijose liekamuosius itempius, kai, atsiradus pirmosioms netamprioms deformacijoms, toliau konstrukcija dirba kaip visiškai tampri. Pastarasis reiškinys yra prisitaikomumo teorijos tyrimu objektas. Prisitaikomumo teorijoje išskirtinos dvi pagrindinès vystymosi kryptys - tai klasikinių Melano-Bleicho (statinè) ir Koiterio (kinematinè) teoremų teiginių praplètimas ir apibendrinimas (tai temperatūros šiluminiu poveikiu, dinaminiu procesu, sustiprèjimo, geometrinio netiesiškumo ir kt. ivertinimas), bei liekamuju deformaciju (postshakedown) ribojimo metodai. Kas liečia metodus, skirtus praktinèms prisitaikomumo problemoms spręsti, pažanga šioje srityje remiasi konstrukcijų diskretizacijos bei matematinio optimizavimo plačiu taikymu. 
Daugybẻ literatūros prisitaikomumo tema verčia daryti kryptingą jos apžvalga, kuri siejasi su disertacijos tema.

\subsection{Pagrindinès prisitaikomumo teoremos}

\subsubsection{Melano statinè prisitaikomumo teorema}

1936 metais Melan (1936) pateikè teoremą skirtą statiškai neišsprendžiamoms konstrukcijoms, kurią pats 1938 metais išplète kontinuumo atvejui, pateikdamas būtinaji prisitaikomumo kriterijų (Melan 1938): konstrukcija prisitaikys, jeigu kiekviename kūno taške egzistuoja nepriklausantys nuo laiko liekamieji įtempiai $\boldsymbol{\sigma}_{r}$ tokie, kad ju suma su kintamaja (,,pseudotampriaja“) itempiu dalimi $\boldsymbol{\sigma}_{e}$ sudaro leistinaji itempiu būvi $\sigma$, esant visoms apkrovu, kintančiu duotose ribose, kombinacijoms. Dabar ši teorema vadinama klasikine statine prisitaikomumo arba Melano teorema.

\subsubsection{Koiterio kinematinè prisitaikomumo teorema}

1956 metais Koiter $(1956,1960)$ pateikè klasikine tapusią kinematinę prisitaikomumo teorema, nusakančią būtinas sąlygas, dèl kurių idealiai tampriai plastiné konstrukcija neprisitaikys: prisitaikomumas neimanomas (t. y. sistema plastinio deformavimo metu suirs), jeigu galima rasti kintančias duotosiose ribose išorines apkrovas $\mathbf{q}$ ir leistinu plastiniu deformaciju greičius $\dot{\boldsymbol{\varepsilon}}_{p}$ tokius, kad $\int_{0}^{T} \int_{S_{f}} \boldsymbol{q}^{T} \dot{\boldsymbol{u}} d S d t>\int_{0}^{T} d t \int_{V} \mathscr{F}\left(\dot{\boldsymbol{\varepsilon}}_{p}\right) d V$. Čia $\mathscr{F}\left(\dot{\boldsymbol{\varepsilon}}_{p}\right)$ - energijos disipacijos cikle T funkcija. Ciklu čia suprantamas laiko tarpas $0 \div T$, per kuri pasireiškia visi charakteringi plastinio irimo požymiai. Kita vertus, sistema prisitaikys, jeigu dèl kintančios duotose ribose apkrovos $\boldsymbol{q}$ ir bet kurių leistinų plastinių deformacijų ciklų $\dot{\boldsymbol{\varepsilon}}_{p}$ galima rasti toki skaičių $s>1$, kad būtų tenkinama nelygybė:

$s \int_{0}^{T} \int_{S_{f}} \boldsymbol{q}^{T} \dot{\boldsymbol{u}} d S d t \leq \int_{0}^{T} d t \int_{V} \mathscr{F}_{(}\left(\dot{\boldsymbol{\varepsilon}}_{p}\right) d V$. Viršutinè skaičiaus $s$ riba yra prisitaikomumo atsargos koeficientas. 


\subsection{Prisitaikomumo analizè}

Prisitaikomumo analizès teorija ir fundamentinè metodologija yra klasikinès mechanikos dalis apie konstrukcijas, veikiamas KKA ir gali būti laikoma praktiškai ir konceptualiai reikšmingu ribinès analizès apibendrinimu. Šiuo požiūriu klasikine teorija ir pagrindine jos raida sistemingai pateikti, pavyzdžiui, Königo ir Maierio (1981), Polizzotto (1982), Königo (1982a; 1987), Kaliszky (1989), Kleibero ir Königo (1990), Kleibero ir Wozniako (1991), Mrózo ir Weicherto (1995), Weicherto ir Maierio (2000; 2002), Jiraseko ir Bažanto (2002) apžvalgose, knygose ir straipsnių rinkiniuose.

Prisitaikomumo analizè, suprantama griežtaja prasme, pagal savo prigimti, suteikia informaciją apie didžiausią stiprumo atsarga, t. y. kritinę reikšmę, už kurios ribų ivyksta neprisitaikomumas, ir liekamuju itempimų pasiskirstymą po prisitaikomumo ar, neprisitaikymo atveju - suirimo kinematini pobūdi (priaugiminis ar mainusis). Metodai, kurie leidžia numatyti konstrukcija prisitaikys ar neprisitaikys (priešingu atveju reikia ịvertinti stiprumo atsarga) turi didelę praktinę svarbą. Taigi, daugelyje techninių situacijų esant kintamiems poveikiams konstrukcijų ekonomiškumas reikalauja pripažinti plastinių deformacijų egzistavimą. Kitaip tariant, tai neišvengiama. Tačiau siekiant kontroliuoti plastinę konstrukcijų elgseną būtina žinoti plastinių deformacijų bei liekamujų poslinkių dydžius susikaupusius iki konstrukcija prisitaiko. O klasikinių prisitaikomumo teoremų taikymas tokios informacijos nesuteikia. Iki 1972 metų nebuvo jokių metodų tamprioms plastinèms deformacijoms įvertinti iki prisitaikomumo būvio. Vèliau tokie metodai pateikti (Vitiello 1972; Ponter 1972, 1975; Capurso et al. 1978; Dorosz 1978) ir net parodyta, kad iki pasiekiant prisitaikomumo būvi praktinèse situacijose, poslinkiai yra tamprumo ribose, net jei stiprumo atsarga neprisitaikymo požiūriu yra maža.

\subsection{Ribojimo metodai}

Daug pastangų buvo i̇dèta siekiant nustatyti prisitaikomumo ribą, kai ribojami atitinkami dydžiai, pavyzdžiui, liekamieji poslinkiai tam tikruose konstrukcijos pjūviuose. Tokie ribojimo metodai naudingi, dažnai būtini konstrukcijos saugumui patikrinti. Pirmiausiai buvo pateikti metodai, itraukiantys apribojimų sąlygas kaip būtinas prisitaikomumo teoremose (Rizzo 1983; Rizzo ir Giambanco 1984). Toks požiūris, grindžiamas ribojimo metodais, itraukiant ribotą valkšnumą, nesudètingoms gelžbetoninėms konstrukcijoms ir plieninèms santvaroms buvo pristatytas Polizzotto (1984), Polizzotto ir Rizzo (1987). Tačiau šis sprendimas yra ne toks populiarus lyginant su išankstiniu atskirų ribų numatymu. Ribų teoremų išsivystymą ir jų platų pritaikymą apibendrina Corigliano Ribu teo- 
remos apytiksliam plastinių deformacijų ir liekamujų poslinkių nustatymui buvo pasiūlytos - Kaneko ir Maierio (1981), Polizzotto (1982), Kaliszky (1996), Lange-Hansen (1998), Tin-Loi (2000), Weicherto ir Maierio (2002).

Geriausių ribų paieška neabejotinai siejama su optimizavimo uždaviniu. Didžioji dalis tyrimų šioje srityje yra tamprių plastinių konstrukcijų analizės uždaviniai, efektyviai panaudojant iteracines procedūras (Pycko 1997; Giambanco et al. 1998 a; Spiliopoulos 1999; Cascario ir Garcea 2002). Daug mažiau išvystytas konstrukcijų optimizavimas prie fiksuotos apkrovos, o darbų apie konstrukcijų optimalų projektavimą prisitaikomumo sąlygomis vis dar yra nedaug ir vykdomi jie pavieniu tyrejjų.

\subsection{Optimalus projektavimas prisitaikomumo sąlygomis}

Pirmosios studijos apie struktūrų optimalu projektavima prisitaikomumo salygomis, minimizuojant rèminių konstrukcijų svori pagal klasikinius optimalumo kriterijus, buvo Heymano (1958). Heymano iteracinè metodika vèliau buvo pritaikyta kitų autorių (Cohn ir Parimi 1973; König 1975; Borkowski ir Atkočiūnas 1975; Save ir Prager 1985; Nguyen ir Morelle 1990). Bandymas apjungti optimizavimo uždavinyje (minimalaus svorio nustatymo) prisitaikomumą su riboto tamprumo ribojimais ir išspręsti šio uždavinio bendriausius atvejus atliktas Polizotto (1984). Polizzotto prieaugiminio priartèjimo esmé yra ta, kad kiekvienos iteracijos metu projekto kintamieji lieka pastovūs ir pakoreguojami kiekvieną kartą prieš kitą iteraciją. Pasiūlytaji modeli, puikiai tinkantị mažiems pavyzdžiams, patobulino Tin-Loi (2000), taikant matematini programavimą su pramoninio modeliavimo sistema didelio masto optimizavimo uždavinio tiesioginiam sprendimui. Optimizavimo uždavinys suformuluotas, remiantis klasikine apatinès ribos prisitaikomumo teorema papildyta liekamujų poslinkių apribojimais.

Optimalaus projekto paieškos (dažniausiai minimalaus svorio arba tūrio) problemos tinkamas formulavimas labiausiai priklauso nuo konkretaus apribojimo kriterijaus pasirinkimo, o tai priklauso nuo pasirinkto konstrukcijos ribinio būvio. Jei ribiniu ịvedamas tamprusis būvis, tuomet formuluojamas tamprus optimizavimo uždavinys, pavyzdžiui, Cinquini et al. (1980); jei pasirenkamas prisitaikymo kriterijus - formuluojamas prisitaikomumo optimalus projektas (Cohn ir Parimi 1973; König 1975; Giambanco et al. 1994a, 1994b, 1998b; Giambanco ir Palizzolo 1995); pagaliau, jei taikomas suirimo ribinis būvis, sudaromas standartinis plastinis optimizavimo uždavinys (Rozvany 1976, 1989; Save ir Prager 1985). Kadangi bet kurioje iš trijų aukščiau minimų formuluočių pasirenkamas tik vienas apribojimo kriterijus, tuo užtikrinamas konstrukcijos optimalus projektas, atitinkantis būtent ši kriterijų, tačiau tokiu būdu ignoruojamos visos kitos 
galimos ribinès būklès. Taigi, taip suprojektuota konstrukcija gali turèti pakankamą stiprumo atsargą staigaus suirimo atžvilgiu, tačiau negali pademonstruoti tinkamą elgseną kitose inžinerinèse situacijose, pavyzdžiui, eksploatacijos metu. Pastaruoju metu, keletas tyrèjų (Giambanco 2000; Palizzolo 2000) pasiūlè vienu metu ivertinti visus tris kriterijus - tai vadinama daugiakriteriniu optimizavimu. Vèliau, Palizzolo (2004), tęsdamas šiuos tyrimus, tampriai plastinei lenkiamai sijai pateikè keturias skirtingas šios problemos formuluotes, grindžiamas dviem ribų teoremomis. Minimalaus tūrio ir maksimalios apkrovos paieškos uždaviniai sudaryti, vienu metu taikant visus aukščiau minètus kriterijus.

\subsection{Dualumas ir matematinis programavimas}

Tiek matematikos, tiek mechanikos požiūriu, dualumas (Malvern 1969), kuris jungia apatinès ir viršutinès ribų teoremas, yra labai patraukli prisitaikomumo teorijos savybè. Ši savybẻ leidžia taikyti vieną iš matematinių optimizavimo teorijų, būtent matematinio programavimo teorija. Todèl mokslinèje literatūroje apie prisitaikomumą kreipinys i dualumą sutinkamas labai dažnai. Maier (1973) pirmasis parode, kad taikant matematinio programavimo metodą, gaunamas tikslus statinio ir kinematinio priejjimo dualumas. Dualumo studijos prisitaikomume vèliau buvo atliktos De Saxcé (1986), Morelle (1989), Kamenjarzh (Kamenjarzh ir Weichert 1992) ir kitų. Pastarieji, panaudodami iškilos analizès priejjima, iš statinès Melano teoremos nustate kinematini atsargos koeficienta. Dualumas tuokart buvo apribotas plonasienių konstrukcijų sferinio takumo paviršiaus atvejais. Dualumo teoremos apibendrinimas platesniam taikymui, siekiant apimti platesnę takumo paviršių klasę, pavyzdžiui, tokius, kaip cilindrinius takumo paviršius; o taip pat ir skirtingus tempimo ir gniuždymo takumo įtempimus, pateiktas Kamenjarzh ir Merzljakov (1994a, 1994b) darbe. Nagrinejant prisitaikomumo analizę, Polizzotto (1993b) parodè tai, jog egzistuoja statinès ir kinematinès formuluočių tiesinis (tiesioginis) dualumas tuo atveju, kai kintamų apkrovų rinkinys yra briaunainis. Dualumo teorijos išplètimas iškilai nedaugiakampei apkrovos sričiai yra Silveira (Zouain ir Silveira 1999) darbe. Čia, prieaugiminiam suirimui panaudojant kinematinę formuluotę gaunama duali statinè formuluotè. Tačiau nors apatinès ir viršutinès prisitaikomumo teoremų dualumas plačiai taikomas optimizavime, diskretinių formų dualumas prisitaikomumo analizeje, vis dar retas reiškinys. Tarp šiu tyrimų, apatinès ir viršutinès prisitaikomumo ribų dualumas, taikant kinematiškai leistinus baigtinius elementus ir Mizeso takumo kriterijų (Vu et al. 2004a, 2004b). Taip sudarytas efektyvus prisitaikomumo analizès algoritmas. Kiti baigtinių elementų ir ekstreminių principų (Lanczos 1970) taikymo prisitaikomume pavyzdžiai - Zouain ir Silveira $(1999,2000)$, Zouain et al. (2002), Polizzotto (2003), Bower (2010). 
Klasikiniai kvazistatinio prisitaikomumo problemu sprendimo metodai pradžioje rèmèsi tiesiniu arba netiesiniu matematiniu programavimu (Maier 1969; Maier et al. 1972; Corradi ir Zavelani 1974; Čyras 1983; Karadeniz ir Ponter 1984), vèliau buvo išplèsti ịvairiems baigtinių elementų tipams (Belytschko 1972; Nguyen ir Morelle 1981; Alwis ir Grundy 1985; Morelle 1986; Ponter et al.1990). Kadangi praktiniams inžineriniams konstrukcijų skaičiavimams labiau tinka diskretiniai matematiniai modeliai, dauguma realių konstrukcijų skaičiuojama baigtinių elementų metodu (Bathe 2006, Barauskas et al. 2004, Smith ir Griffits 2004). Tuo būdu uždavinys suvedamas ỉ lygčių sprendima, tačiau šios lygtis yra algebrinès, o ne diferencialinès. Todèl daug šiuolaikinių programiniu paketų priedų, skirtų konstrukcijų optimizavimui plačiai naudoja nuolat augančių kompiuterinių technologiju galinguma, derinant konstrukcijų diskretizaciją su tiesioginio sprendimo metodais. Pavyzdžiui, netiesinio programavimo metodo realizacija komerciniame baigtinių elementų programų pakete, sprendžiant prisitaikomumo problemas, aprašoma Ponter (Ponter et al. 2000; Ponter ir Engelhardt 2000) darbuose; prisitaikymo apkrovos apatinès ribos skaičiavimas, taikant baigtinių elementų programini paketą (Muscat et al. 2003).

Matematinio programavimo teorija nuo pat pirmuju jos taikymu prisitaikomumo tyrimuose yra ne tik efektyvus įrankis skaitiniams prisitaikomumo uždaviniams spręsti, bet ir matematinè struktūra, sudarant ir aprašant šiuos uždavinius (Maier 1969, 1970; Corradi ir Zavelani 1974; Atkočiūnas 1994, 1999; Čyras 1989; Čyras et al. 2004; Kalanta 2007;). Tarp sunkumų praktiniam inžineriniam matematinio programavimo taikymui prisitaikomume reikètu paminèti prisitaikančios konstrukcijos lokalinių liekamujų poslinkių ir plastinių deformacijų îvertinimą (Atkočiūnas et al. 1981). Šios problemos sprendimą optimizuojant prisitaikančias strypines sistemas demonstruoja Ferris (Ferris ir Tin-Loi 1997), Kaliszky (Kaliszky ir Logo 1997, 2002) darbai. Pažymėtina matematiniame modelyje taikomo takumo kriterijaus svarba. Ankstesniuose prisitaikomumo tyrimuose buvo vystomas tiesinis programavimas, taikant Treska kriteriju arba linearizuotą takumo kriterijų. Taikant Mizeso kriterijų prisitaikomumo uždavinys tampa netiesinio programavimo problema, kurios sprendimas esant sudètingai konstrukcijai ar apkrovimui praktiniams inžineriniams tikslams vis dar yra iššūkis.

\subsection{Pirmojo skyriaus išvados ir disertacijos uždavinių formulavimas}

Atlikę prisitaikančių konstrukcijų optimizavimo metodų apžvalgą galime padaryti tokias išvadas: 
1. Statybos inžinerijoje realūs konstrukciją veikiantys poveikiai yra cikliški, todèl prisitaikomumo teorijos taikymas konstrukcijų saugumo įvertinime yra svarbus, dažnai būtinas, reikalavimas.

2. Optimizavimo uždavinių matematiniuose modeliuose įvertinama poslinkių liekamoji dalis: dažniausiai taikoma žinoma Koiterio nelygybè. Būtina pasitelkti liekamujų poslinkių influentinę matricą.

3. Pramoninejje programinèje irangoje ciklinè apkrova įvertinama pasitelkus apkrovimo istorijas. Deja tai gali neužtikrinti konstrukcijos prisitaikomumo pilnutinès analizès.

4. Akivaizdu, kad egzistuojančioms metodikoms trūksta sąsajų tarp prisitaikančių konstrukcijų teorija pagrįstų optimizavimo metodų ir standartais gristo realaus projektavimo.

5. Išryškejja nesugebejjimas įvertinti apkrovos derinius plastiniame skaičiavime.

6. Prisitaikančių konstrukcijų optimizavimo metodika ir sintezė su realiu projektavimu nepakankamai išvystyta.

Taigi norint prisitaikomumo teoriją taikyti statybos inžinerijos praktinių uždavinių sprendimui reikia išspręsti šiuos uždavinius (etapus):

1. Sukurti prisitaikančių konstrukcijų tikrinamojo ir projektinio optimizavimo uždavinių patikslintus matematinius modelius, i standumo apribojimus jjungiant suminius (tamprius ir liekamuosius) poslinkius.

2. Skaitineje analizèje atsisakyti skerspjūvių idealizacijos, įvesti profiliuočių realius skerspjūvio parametrus.

3. Sukurti programinę irangą prisitaikančių konstrukcijų analizei ir optimizavimui realizuojančią patikslintus matematinius modelius.

4. Sukurti metodiką leidžiančią autoriaus programinès ịangos apskaičiuotus plastinio būvio kintamuosius (liekamąsias iražas ir liekamuosius poslinkius) integruoti i kompiuterinio paketo MatrixFrame (arba analogiškos programos) atliekamą konstrukcijos analizès procesą.

5. Sukurti KKA ir projektavimo standartų sąsajas.

6. Atlikti skaičiavimus iliustruojančius prisitaikančiu strypinių konstrukcijų optimizavimą. 



\section{2}

\section{Patobulinti prisitaikančiu konstrukciju optimizavimo modeliai}

Praktiniuose konkrečių konstrukcijų skaičiavimuose naudojami konstrukcijų diskretiniai modeliai, kurie sudaromi laikantis tam tikrų geometrinių ir fizikiniu skaičiavimo prielaidų. Būtent diskretizacijai, bei projektiniam ir patikrinamajam prisitaikančių konstrukcijų optimizavimo uždavinių matematinių modelių sudarymui ir yra skirtas šis skyrius. Prisitaikančių konstrukcijų KKA apibrèžiančios jègos, tenkinančios sistemos prisitaikomumo sąlygas, lètai (kvazistatiškai) kinta laike $t$. Paprastai žinomos tik viršutinès ir apatinès jègų kitimo ribos. Visos galimos apkrovimo programos laikomos vienodai tikètinomis (deterministinis uždaviniu formulavimas). Sistemos deformacijos mažos, t. y. geometrinès lygtys tiesinès, pusiausvyros lygčių koeficientų matrica sudaroma jos būviui. Taip pat laikomasi mažu poslinkių prielaidos. Konstrukcijos medžiaga - idealai tampriai plastiška, cikliškai stabili (deformavimo diagrama nepriklauso nuo aprovimonukrovimo ciklų skaičiaus).

Skyriaus tematika paskelbti du autoriaus straipsniai (Atkočiūnas et al. 2008a, Kalanta et al. 2009). 


\subsection{Diskretinès sistemos ịrąžos ir deformacijos}

Prisitaikiusių konstrukcijų optimizavimo problemos sprendžiamos, kai apkrovos kitimo ribos $\boldsymbol{F}_{\text {inf }}, \boldsymbol{F}_{\text {sup }}$ yra tokios, kad konstrukcija, per pradinius apkrovos ciklus patyrusi plastines deformacijas $\boldsymbol{\Theta}_{p}$, vèliau prisitaiko prie pateiktos apkrovos ir toliau dirba tampriai (Konig ir Maier 1981; Atkočiūnas ir Čižas 2009; Atkočiūnas ir Karkauskas 2010). Dèl plastinių deformacijų $\boldsymbol{\Theta}_{p}$ itakos prisitaikiusioje sistemoje atsiranda liekamuju iražžu $\boldsymbol{S}_{r}$, kurios ir užtikrina, kad kintant apkrovai, naujų plastinių deformacijų nebesusidarys (tampriosios konstrukcijos skaičiavimo kintamieji disertacijoje indeksuojami raide $e$, liekamosios irąžos, deformacijos ir poslinkiai - indeksu $r$ ). Todèl prisitaikiusių konstrukcijų analizèje patogu išskirti liekamąsias įrąžas $\boldsymbol{S}_{r}$ (jos yra saupusiausviros, t. y. tenkinančios pusiausvyros lygtis, kai $\boldsymbol{F}=\mathbf{0}$ ), poslinkius $\boldsymbol{u}_{r}$ ir deformacijas $\boldsymbol{\Theta}_{r}$. Pusiausvyros ir geometrinès lygtys užrašomos taip:

$$
\begin{gathered}
\boldsymbol{A} \boldsymbol{S}_{r}=\mathbf{0}, \\
\boldsymbol{A}^{T} \boldsymbol{u}_{r}=\boldsymbol{\Theta}_{r}, \\
\boldsymbol{\Theta}_{r}=\boldsymbol{D} \boldsymbol{S}_{r}+\boldsymbol{\Theta}_{p} .
\end{gathered}
$$

Čia (2.1) ir (2.2) yra pusiausvyros ir geometrinès lygtys atitinkamai. $\boldsymbol{S}_{r}=\left\{S_{r 1}, S_{r 2}, \ldots, S_{r n}\right\}$ - liekamujų irąžų, kurių bendras skaičius yra $n$, vektorius, $\boldsymbol{D}-(n \times n)$ eilès kvazidiagonalioji atskirų elementų pasiduodamumų matrica, $\boldsymbol{\Theta}_{p}$ - plastinių deformacijų vektorius. Vektorių $\boldsymbol{u}_{r}, \boldsymbol{\Theta}_{p}$ struktūra yra tokia: $\boldsymbol{u}_{r}=\left\{u_{r 1}, u_{r 2}, \ldots, u_{m r}\right\}, \boldsymbol{\Theta}_{p}=\left\{\Theta_{p 1}, \Theta_{p 2}, \ldots, \Theta_{p n}\right\}$. Suminiai dydžiai žymimi:

$$
\boldsymbol{S}=\boldsymbol{S}_{r}+\boldsymbol{S}_{e}, \quad \boldsymbol{u}=\boldsymbol{u}_{r}+\boldsymbol{u}_{e}, \quad \boldsymbol{\Theta}=\boldsymbol{\Theta}_{r}+\boldsymbol{\Theta}_{e} .
$$

Diskretinès konstrukcijos įtempių būvis (Atkočiūnas 1999) išreiškiamas įrąžų vektoriumi $\boldsymbol{S}=\left\{\boldsymbol{S}_{1}, \boldsymbol{S}_{2}, \ldots, \boldsymbol{S}_{\zeta}\right\}, \zeta=\mathrm{s} \times v$. Čia $s$-diskretini modeli sudarančių baigtinių elementų skaičius $(k=1,2, \ldots, s, k \in K)$, kur $v$ - kiekvieno elemento mazgų (skaičiuojamujų pjūvių) skaičius $(l=1,2, \ldots, v, l \in \mathscr{L})$. Taigi dydis $\zeta$ yra bendras konstrukcijos diskretinio modelio mazgų skaičius $(i=1,2, \ldots, \zeta$, $i \in I$ ). Vektoriaus $\boldsymbol{S}$ komponentais gali būti lenkimo momentai $M$, skersinès $Q$, ašinès jègos $N$. Pagrindinè disertacijos nagrinejjama konstrukcija yra rèmai, todèl $\boldsymbol{S}$ vektoriuje bus įvertinami lenkimo momentai $M$ ir ašinès jègos $N$ (arba tik $M)$. Su ịrąžų vektoriumi $\boldsymbol{S}=\left\{\boldsymbol{S}_{1}, \boldsymbol{S}_{2}, \ldots, \boldsymbol{S}_{\zeta}\right\}=\left\{S_{1}, S_{2}, \ldots, S_{n}\right\}$ yra sude- 
rintas deformaciju vektorius $\boldsymbol{\Theta}=\left\{\boldsymbol{\Theta}_{1}, \boldsymbol{\Theta}_{2}, \ldots, \boldsymbol{\Theta}_{\zeta}\right\}=\left\{\Theta_{1}, \Theta_{2}, \ldots, \Theta_{n}\right\}$. Suderinamumas reiškia, kad kiekvieno vektoriaus $\boldsymbol{S}$ ir $\boldsymbol{\Theta}$ komponentų skaičius yra vienodas ir lygus $n\left(n=s \times v \times n_{v}=\zeta \times n_{v}\right.$, čia $n_{v}$ yra ịrą̌̌u skaičius mazge (pjūvyje)). Disertacijoje nagrinejjamų rèmų atveju laikoma, kad pjūvyje plastines deformacijas lemia ir $M$, ir $N$, todèl įrąžų rodiklis $n_{v}=2$.

Kita dualių kintamuju pora yra apkrovos $\boldsymbol{F}$ ir poslinkiai $\boldsymbol{u}$. Šių vektorių komponentų skaičius yra lygus konstrukcijos diskretinio modelio laisvès laipsniui $m$. Pusiausvyros lygčių koeficientų matricos $\boldsymbol{A}$ eilučių ir stulpelių skaičius lygus diskretinio modelio globalinių poslinkių bei iražų skaičiui $m$ ir $n$ atitinkamai. Tada visos diskretinés sistemos pusiausvyros lygtys užrašomos

$$
\boldsymbol{A} \boldsymbol{S}=\boldsymbol{F} \text { arba } \sum_{k} \boldsymbol{A}_{k} \boldsymbol{S}_{k}=\boldsymbol{F} .
$$

Čia $\boldsymbol{S}=\left\{S_{1}, S_{2}, \ldots, S_{n}\right\}, \boldsymbol{F}=\left\{F_{1}, F_{2}, \ldots, F_{m}\right\}-$ irą̌ŭ ir apkrovų vektoriai, o $\boldsymbol{A}_{k}-k$ - tojo baigtinio elemento pusiausvyros lygčiu matrica. Tuomet geometrinès lygtys užrašomos taip:

$$
\boldsymbol{A}^{T} \boldsymbol{u}=\boldsymbol{\Theta}
$$

Čia $\Theta=\left\{\Theta_{1}, \Theta_{2}, \ldots, \Theta_{n}\right\}, \boldsymbol{u}=\left\{u_{1}, u_{2}, \ldots, u_{m}\right\}-$ deformacijų ir poslinkių vektoriai.

Disertacijoje laikoma, kad konstrukcijos pjūvis gali būti arba tampraus, arba plastinio būvio (darbe naudojami I tipo skerspjūviai, kurių forma artima idealiam skerspjūviui). Takumo sąlygos nusako kokio tipo yra konstrukcijos pjūvis. Pritaikius skaliarinę ir iškylają takumo funkciją $f$, takumo sąlygos užrašomos kiekvienam diskretinio modelio mazgo taškui $i(i=1,2, \ldots, \zeta=s \times v)$ :

$$
f_{i}\left(\boldsymbol{S}_{i}\right) \leq S_{0 i}, i=1,2, \ldots \zeta, i \in I .
$$

Čia $S_{0 i}$ yra pjūvio ribinè iražža (pvz., lenkiamai sijai tai būtų ribinis momentas $M_{0}$ ). Dažnai netiesinè sąlyga (2.7) užrašoma tokiu pavidalu:

$$
\varphi_{i}=S_{0 i}-f_{i}\left(\boldsymbol{S}_{i}\right) \geq 0 .
$$

Kai rèmo diskretinio modelio mazge veikia lenkimo momentas $M$ ir ašinè jèga $N$, tuomet rémo stiprumo charakteristikos yra ribinis lenkimo momentas $M_{0}=\sigma_{y} W_{p l}$ ir ribinè ašinè jèga $N_{0}=\sigma_{y} A$; čia $W_{p l}$ - plastinis skerspjūvio atsparumo momentas, $A$ - skerspjūvio plotas. Nors elemento skerspjūvio forma gali būti ịvairi, disertacijoje, kaip jau buvo minèta, KKA atveju orientuojamasi ị I tipo skerspjūvi, kurio skerspjūvio formos koeficientas $\mu=1,15 \ldots 1,17$. Tai 
leidžia tiksliau priartèti prie idealiai tamprios plastinès elgsenos (Prantlio diagramos). Sąlyga (2.8) rèmo uždavinių matematiniuose modeliuose dažnai taikoma kaip tiesinè takumo (stiprumo) sąlyga:

$$
|M|+c|N| \leq M_{0}, \quad c=\frac{M_{0}}{N_{0}} .
$$

Taigi šiuo atveju $S_{0}=M_{0}$. Disertacijoje sąlyga (2.9) užrašoma keturių arba šešių nelygybių sistemomis, grafiškai jos pavaizduotos 2.1 pav.
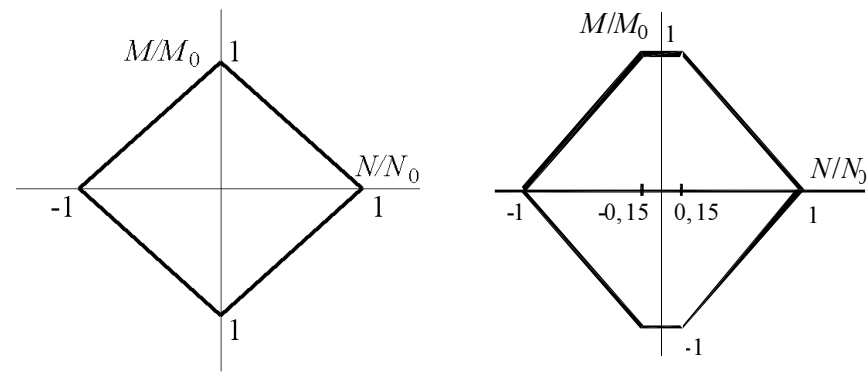

2.1 pav. Tiesinès takumo sąlygos

Fig. 2.1. Linear yield conditions

Visam diskretiniam konstrukcijos modeliui takumo sąlygos (2.9) užrašomos taip:

$$
f(S) \leq S_{0}
$$

o jų reikšmių vektorius $\varphi$ yra

$$
\varphi=S_{0}-f(S)
$$

\subsection{Tampriujų iražžu hodografas}

Kartotinè-kintamoji apkrova $\boldsymbol{F}(t)$ išreiškiama ne konkrečia apkrovimo istorija, o tik viršutinemis ir apatinèmis savo kitimo ribomis $\boldsymbol{F}_{\text {sup }}=\left\{F_{1, \text { sup }}, F_{2, \text { sup }}, \ldots, F_{m, \text { sup }}\right\}, \quad \boldsymbol{F}_{\text {inf }}=\left\{F_{1, \text { inf }}, F_{2, \text { inf }}, \ldots, F_{m, \text { inf }}\right\}$, kurios nepriklauso nuo laiko $t\left(\boldsymbol{F}_{\text {inf }} \leq \boldsymbol{F}(t) \leq \boldsymbol{F}_{\text {sup }}\right)$. Taigi apkrovos vektoriaus $\boldsymbol{F}$ komponentu skaičius yra lygus konstrukcijos diskretinio modelio laisvès laipsniui $m$, t. y. ju 
yra tiek, kiek yra pusiausvyros lygčių $\boldsymbol{A} \boldsymbol{S}=\boldsymbol{F}$. Tamprumo sprendinio iražǔu $\boldsymbol{S}_{e}(t)$ kitimo sritis, atsižvelgiant i galimas apkrovų $\boldsymbol{F}_{\text {sup }}, \boldsymbol{F}_{\text {inf }}$ kitimo ribų kombinacijas $j$ (ju yra $p=2^{m}, j=1,2, \ldots, p, j \in J$ ), yra ribojama iškilo ir simetriško savo centro atžvilgiu hodografo. Tampraus skaičiavimo vektoriai $\boldsymbol{S}_{e j}$ yra tiesinès apkrovos kitimo ribų $\boldsymbol{F}_{\text {inf }}, \boldsymbol{F}_{\text {sup }}$ funkcijos ir išreiškia visas hodografo

$$
\begin{gathered}
\boldsymbol{S}_{e}(t)=\boldsymbol{\alpha} \boldsymbol{F}(t), \\
\boldsymbol{\alpha}=\boldsymbol{D}^{-1} \boldsymbol{A}^{T}\left(\boldsymbol{A} \boldsymbol{D}^{-1} \boldsymbol{A}^{T}\right)^{-1},
\end{gathered}
$$

viršūnes $j=1,2, \ldots, p, j \in J$. Čia $\boldsymbol{\alpha}$-tamprių irąžų infliuentinè matrica.

\subsection{Kartotinès-kintamosios apkrovos takumo sąlygos}

Pritaikius tampraus konstrukcijos skaičiavimo iražžų vektorius $\boldsymbol{S}_{e j}, j \in J$, takumo sąlygos (2.12) užrašomos:

$$
\begin{gathered}
\varphi_{k l, j}=S_{0 k}-f_{k l, j}\left(\boldsymbol{S}_{r k l}+\boldsymbol{S}_{e k l, j}\right) \geq 0, \\
k \in K, l \in \mathscr{L}, j \in J
\end{gathered}
$$

Visos konstrukcijos takumo sąlygos $f(\boldsymbol{S}) \leq \boldsymbol{S}_{0}$ užrašomos sekančiai:

$$
\boldsymbol{f}_{j}\left(\boldsymbol{S}_{r}+\boldsymbol{S}_{e j}\right) \leq \boldsymbol{S}_{0}, \quad j \in J .
$$

Panaudojus takumo sąlygos (2.16) išvengiamas apkrovimo istorijos nagrinejjimas (tam ir naudojamos tampraus skaičiavimo įrąžos $\boldsymbol{S}_{e j}$ ). Vienkartès apkrovos atveju skaičiuojamajam pjūviui rašoma „viena“ takumo sąlyga, kadangi yra viena apkrovos viršūnè $j=1$, o KKA atveju pjūviui rašomų takumo sąlygų skaičių nulemia apkrovų kitimo ribų vektorių $\boldsymbol{F}_{\text {sup }}, \boldsymbol{F}_{\text {inf }}$ komponentų galimų tarpusavio kombinacijų skaičius $p=2^{m}(j=1,2, \ldots, p, j \in J)$. Statiškai leistinos liekamosios iražžos $\boldsymbol{S}_{r}$ tenkina pusiausvyros lygtis (2.12) bei takumo sąlygas (2.15) arba (2.16). 


\subsection{Prisitaikiusios sistemos geometrinès lygtys}

Prisitaikiusios sistemos geometrinès lygtys, gautos pagal (2.2), (2.3) priklausomybes:

$$
\boldsymbol{A}^{T} \boldsymbol{u}_{r}=\boldsymbol{D} \boldsymbol{S}_{r}+\boldsymbol{\Theta}_{p},
$$

čia $\boldsymbol{\Theta}_{p}=\left(\boldsymbol{\Theta}_{p k l}\right)^{T}$ - plastinių deformacijų vektorius. Vektoriaus $\boldsymbol{\Theta}_{p}$ komponentai $k$-tojo baigtinio elemento $l$-tajam pjūviui yra apskaičiuojami pagal formulę:

$$
\begin{gathered}
\boldsymbol{\Theta}_{p k l}=\sum_{j}\left[\nabla^{T} f_{k l, j}\left(\boldsymbol{S}_{r k l}+\boldsymbol{S}_{e k l, j}\right)\right] \lambda_{k l, j}, \\
\lambda_{k l, j}\left[S_{0 k}-f_{k l, j}\left(\boldsymbol{S}_{r k l}+\boldsymbol{S}_{e k l, j}\right)\right]=0, \lambda_{k l, j} \geq 0 ; \\
k \in K, l \in \mathscr{L}, \quad j \in J .
\end{gathered}
$$

Čia

$$
\left[\nabla^{T} f_{k l, j}\left(\boldsymbol{S}_{r k l}+\boldsymbol{S}_{e k l, j}\right)\right]=\left[\frac{\partial f_{k l, j}\left(\boldsymbol{S}_{r k l}+\boldsymbol{S}_{e k l, j}\right)}{\partial \boldsymbol{S}_{r k l}}\right]
$$

- takumo sąlygų (2.15) gradientų matrica, $\lambda_{j}$ - plastinių daugiklių vektoriai, $j \in J$. Lygybès

$$
\lambda_{k l, j}\left\lfloor S_{0 k}-f_{k l, j}\left(\boldsymbol{S}_{r k l}+\boldsymbol{S}_{e k l, j}\right)\right\rfloor=0,
$$

kai

$$
\begin{gathered}
S_{0 k}-f_{k l, j}\left(S_{r k l}+S_{e k l, j}\right) \geq 0, \lambda_{k l, j} \geq 0 ; \\
k \in K, l \in \mathscr{L}, j \in J
\end{gathered}
$$

vadinamos matematinio programavimo griežtumo sąlyga. Kinematiškai galimi liekamieji poslinkiai $\boldsymbol{u}_{r}$ yra tie, kurie tenkina geometrines lygtis (2.17).

\subsection{Projektinio uždavinio matematinis modelis}

Konstrukcijos parametrų optimizavimo uždavinys formuluojamas taip: esant pateiktoms apkrovos kitimo riboms $\boldsymbol{F}_{\text {inf }}, \boldsymbol{F}_{\text {sup }}$, rasti ribiniu ìražu vektoriu $\boldsymbol{S}_{0}$, tenkinanti optimalumo kriteriju $\min \psi\left(\boldsymbol{S}_{0}\right)$ ir konstrukcijos prisitaikomumo, konstrukcines bei standumo apribojamasias salygas. 
Tiesinių takumo sąlygų atveju prisitaikančios holonominès elgsenos konstrukcijos projektinio uždavinio matematinis modelis, kai neatsižvelgiama į konstrukcijos skerspjūvių nusikrovima, yra toks: rasti

$$
\min \psi\left(\boldsymbol{S}_{0}\right)
$$

kai

$$
\begin{gathered}
\boldsymbol{\varphi}_{j}=\boldsymbol{\Gamma} \boldsymbol{S}_{0}-\boldsymbol{\Phi}\left(\boldsymbol{G} \lambda+\boldsymbol{S}_{e j}\right) \geq \mathbf{0}, \\
\lambda_{j}^{T} \boldsymbol{\varphi}_{j}=0, \\
\lambda_{j} \geq \mathbf{0}, \lambda=\sum_{j} \lambda_{j}, j \in J, \\
\boldsymbol{S}_{\text {min }} \leq \boldsymbol{S}_{0} \leq \boldsymbol{S}_{\max } \\
\boldsymbol{u}_{r, \min } \leq \boldsymbol{H} \lambda \leq \boldsymbol{u}_{r, \max } .
\end{gathered}
$$

Tikslo funkcijos (2.22) skaliarinei funkcijai $\psi$ galima suteikti konkrečią ekonominę interpretaciją. Paprasčiausias ir praktiškai įdomus atvejis yra minimalaus svorio konstrukcijos uždavinys. Idealios skerspjūvio formos ir homogeninès takumo sąlygos atveju minimalus konstrukcijos svoris koreliuoja su tiesine tikslo funkcija $\min \boldsymbol{L}^{T} \boldsymbol{S}_{0}$. Čia $\boldsymbol{L}$ yra optimalumo kriterijaus (2.22) svorio koeficientu vektorius. Minimalaus svorio konstrukcijos projektavimo atveju visos medžiagos savybès pateiktos, gali kisti tik elemento ar pjūvio matmenys. Taigi tampriosios konstrukcijos irą̧̌u vektorius $\boldsymbol{S}_{e}$ kinta, sprendžiant uždavini (2.22)-(2.27) jis turètų būti perskaičiuojamas pagal naują skaičiuojamojo pjūvio geometriją. Uždavinyje (2.22)-(2.27) nežinomieji yra ribinių irąžų vektorius $\boldsymbol{S}_{0}$ ir plastinių daugiklių vektorius $\lambda^{*} . \boldsymbol{G}=\overline{\boldsymbol{G}} \boldsymbol{\Phi}^{T}$ ir $\boldsymbol{H}=\overline{\boldsymbol{H}} \boldsymbol{\Phi}^{T}$ yra infliuentinès liekamujų iražžu ir poslinkių matricos. Apribojimai (2.23) nustato statiškai leistinų liekamujų iražų vektorių $\boldsymbol{S}_{r}$ ir kartu užtikrina tampriosios plastinès sistemos prisitaikymą prie pateiktos KKA $\boldsymbol{F}_{\text {inf }} \leq \boldsymbol{F}(t) \leq \boldsymbol{F}_{\text {sup }}$ (Melano ir Bleicho teorema). Sąlygos (2.23) kartu su matematinio programavimo griežtumo sąlygomis (2.24) užtikrina, kad bus tenkinamas papildomos deformavimo energijos minimumo principas min $\mathscr{F}^{\prime}\left(S_{r}\right)=\min \frac{1}{2} \boldsymbol{S}_{r}^{T} \boldsymbol{D} \boldsymbol{S}_{r}$. Tik tokiu atveju vektoriaus $\lambda^{*}$ komponentai igauna plastinių daugiklių prasmę ir tampa įmanoma taikyti formu- 
les $\boldsymbol{S}_{r}=\boldsymbol{G} \lambda^{*}, \boldsymbol{u}_{r}=\boldsymbol{H} \lambda^{*}$. Būtina pabrèžti, kad konstrukcijos prisitaikomumo būvi užtikrina ne papildomos energijos $\mathscr{F}^{\prime}\left(\boldsymbol{S}_{r}^{*}\right)=\frac{1}{2} \boldsymbol{S}_{r}^{* T} \boldsymbol{D} \boldsymbol{S}_{r}^{*}$ minimali reikšmè, o tik faktas, kad egzistuoja bet koks statiškai leistinas liekamujų iražž vektorius $\boldsymbol{S}_{r}$. Šis teiginys yra tiesioginè klasikinès Melano ir Bleicho teoremos išvada, išplètota konstrukcijai. Konstrukcinių apribojimų sąlyga (2.26) nusako ribinių irąžu kitimas sriti per vektorius $\boldsymbol{S}_{\min }$ ir $\boldsymbol{S}_{\max }$. Standumo sąlyga (2.27) naudojama apriboti liekamiesiems poslinkiams dydžiais per $\boldsymbol{u}_{r, \min }$ ir $\boldsymbol{u}_{r, \max }$. Jeigu standumo sąlygos (2.27) apskritai būtų ignoruojamos, uždavinio (2.22)-(2.26) sprendimo rezultatas atitiktų konstrukcijos būvị, labai artimą ciklinei plastiškajai suirčiai (bet ne patị ciklinès plastiškosios suirties momentą!).

Nesudètinga îvertinti ir apribojimų (2.27) tampraus skaičiavimo poslinkius, panaudojant vektorius $\boldsymbol{u}_{e}$ t. $\mathrm{y}$.

$$
\boldsymbol{u}_{\min } \leq \boldsymbol{H} \boldsymbol{\lambda}+\boldsymbol{u}_{e} \leq \boldsymbol{u}_{\max }
$$

čia vektoriai $\boldsymbol{u}_{\min }$ ir $\boldsymbol{u}_{\max }$ nusako jau nebe liekamujuc poslinkių $\boldsymbol{u}_{r}=\boldsymbol{H} \boldsymbol{\lambda}$, bet suminių poslinkių $\boldsymbol{u}=\boldsymbol{u}_{r}+\boldsymbol{u}_{e}$ apribojimus. Pažymètina, jog tamprūs poslinkiai skaičiuojami pagal formulę $\boldsymbol{u}_{e}=\boldsymbol{\beta} \boldsymbol{F}(t)$, kur $\boldsymbol{\beta}=\left(\boldsymbol{A} \boldsymbol{D}^{-1} \boldsymbol{A}^{T}\right)^{-1}-$ tamprių poslinkių influentinè matrica.

\subsection{Projektinio uždavinio pavyzdys}

Trijų aukštų rèmo (2.2 pav.) tūrio minimizacija yra vykdoma pagal matematini modeli (2.22)-(2.27). Optimizavimo tikslas yra rasti minimalų prisitaikiusio rèmo tūri (2.2 pav.) kai diskretinio modelio irą̌ǔų vektorius yra $\boldsymbol{S}=(\boldsymbol{M}, \boldsymbol{N})^{T}$ $=\left(M_{1}, M_{2}, M_{3}, \ldots, M_{31}, N_{1}, N_{2}, \ldots, N_{13}\right)^{T}=\left(S_{i}\right)^{T}, \quad i=1,2, \ldots, n=44$, kuriame yra iverti ir lenkimo momentai $M$ bei ašinès jègos $N$. Uždavinio nežinomieji yra kolonų ir sijų skerspjūvio plotai $A_{k}, k \in K$ ir plastinių daugiklių vektoriai $\lambda_{j}$, $j=1,2, \ldots, p$.

Rėmas (2.2 pav.) yra diskretizuojamas pusiausvyraisiais ir mišriaisiais baigtiniais elementais (Kalanta 2007). 


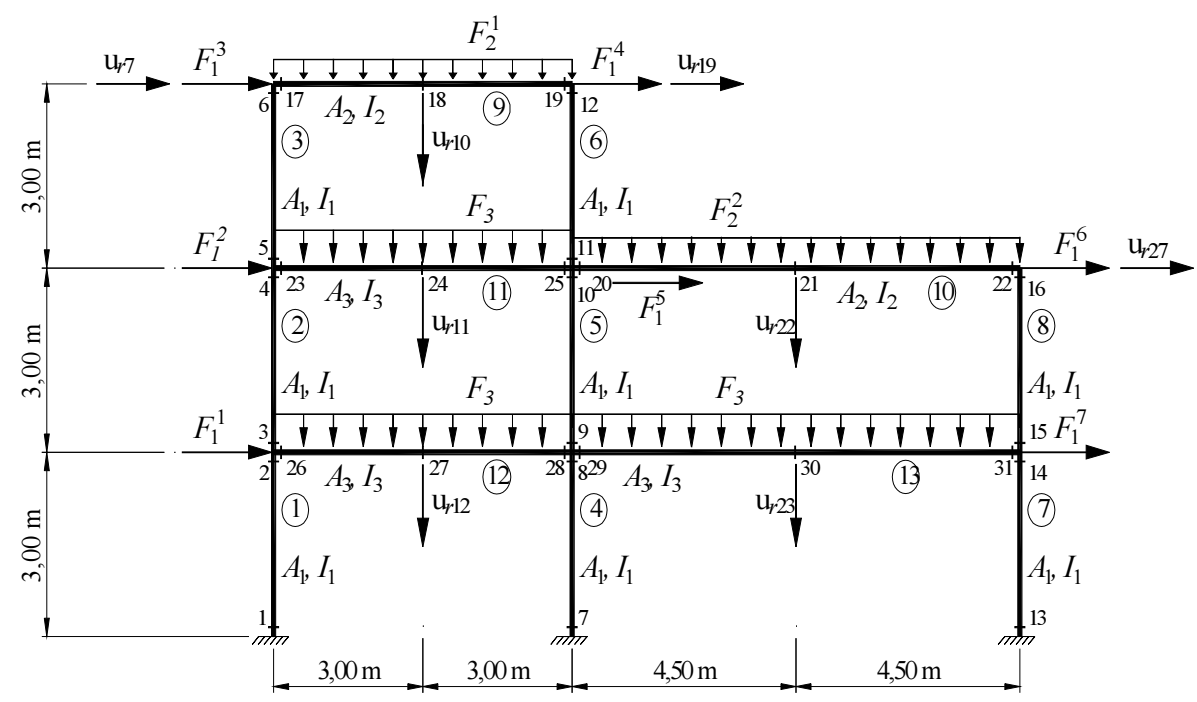

2.2 pav. Rèmo diskretinis modelis

Fig 2.2. Discretized frame

Pusiausvyrieji baigtiniai elementai su šešiais laisvès laipsniais yra naudojami lenkiamoms ir gniuždomoms kolonoms modeliuoti, o mišrieji elementai su septyniais laisvès laipsniais (2.3 pav.), kurių vieną laisvės laipsni atitinka vidurinio pjūvio illinkis, yra naudojami lenkiamoms ir tolygiai išskirstytu krūviu apkrautoms sijoms modeliuoti. Pastarasis baigtinis elementas tiksliai modeliuoja siju itempimų ir deformacijų būvị ir igalina tiesiogiai apskaičiuoti sijų vidurio poslinkius $u_{r 10}, u_{r 11}, u_{r 12}, u_{r 22}, u_{r 23}$.

Rèmas yra apkrautas trimis nesusietomis apkrovomis $\left(p=2^{3}=8\right)$ : horizontaliomis koncentruotomis jègomis $\boldsymbol{F}_{1}=\left[F_{1}^{1}, F_{1}^{2}, F_{1}^{3}, F_{1}^{4}, F_{1}^{5}, F_{1}^{6}, F_{1}^{7}\right]$ veikiančiomis rèmo mazguose ir vertikaliomis tiesiogiai išskirstytomis jègomis $\boldsymbol{F}_{2}=\left[F_{2}^{1}, F_{2}^{2}\right]$ veikiančiomis ant stogo sijų, bei $\boldsymbol{F}_{3}=\left[F_{3}\right]$ veikiančiomis ant grindų sijų, atitinkamai. Apkrovos kitimo ribos yra užrašomos nelygybėmis: $\boldsymbol{F}_{1, \text { inf }} \leq \boldsymbol{F}_{1} \leq \boldsymbol{F}_{1, \text { sup }}, \quad \boldsymbol{F}_{2, \text { inf }} \leq \boldsymbol{F}_{2} \leq \boldsymbol{F}_{2, \text { sup }} \quad$ ir $\quad \boldsymbol{F}_{3, \text { inf }} \leq \boldsymbol{F}_{3} \leq \boldsymbol{F}_{3, \text { sup }}, \quad$ kur $\boldsymbol{F}_{1, \text { inf }}=\{-5,16,-6,06,-3,6,-7,8,-6,6,-6,0-10,2\} \mathrm{kN}, \quad \boldsymbol{F}_{1, \text { sup }}=\{10,2,12,6,7,8$, $3,6,3,36,2,7,5,16\} \mathrm{kN}, \quad \boldsymbol{F}_{2, \text { inf }}=\{0,0\}, \quad \boldsymbol{F}_{2, \text { sup }}=\{2,52,5,22\} \mathrm{kN} / \mathrm{m}, \quad \boldsymbol{F}_{3, \text { inf }}=\{0\} \quad$ ir $\boldsymbol{F}_{3, \text { sup }}=\{30\} \mathrm{kN} / \mathrm{m}$, kurias atitinka $p=8$ apkrovimo kombinacijos: $\boldsymbol{F}_{1, \text { sup }}+\boldsymbol{F}_{2, \text { sup }}+\boldsymbol{F}_{3, \text { sup }} ; \quad \boldsymbol{F}_{1, \text { sup }}+\boldsymbol{F}_{2, \text { sup }}+\boldsymbol{F}_{3, \text { inf }} ; \quad \boldsymbol{F}_{1, \text { sup }}+\boldsymbol{F}_{2, \text { inf }}+\boldsymbol{F}_{3, \text { inf }} ;$ 


$$
\begin{array}{lll}
\boldsymbol{F}_{1, \text { sup }}+\boldsymbol{F}_{2, \text { inf }}+\boldsymbol{F}_{3, \text { sup }} ; & \boldsymbol{F}_{1, \text { inf }}+\boldsymbol{F}_{2, \text { sup }}+\boldsymbol{F}_{3, \text { sup }} ; & \boldsymbol{F}_{1, \text { inf }}+\boldsymbol{F}_{2, \text { sup }}+\boldsymbol{F}_{3, \text { inf }} ; \\
\boldsymbol{F}_{1, \text { inf }}+\boldsymbol{F}_{2, \text { inf }}+\boldsymbol{F}_{3, \text { inf }} ; & \boldsymbol{F}_{1, \text { inf }}+\boldsymbol{F}_{2, \text { inf }}+\boldsymbol{F}_{3, \text { sup }} . &
\end{array}
$$

Rèmas pagamintas iš plieno, kurio tamprumo modulis $E=21000 \mathrm{kN} / \mathrm{cm}^{2}$ ir takumo riba $\sigma_{y}=23,5 \mathrm{kN} / \mathrm{cm}^{2}$. Rèmo kolonų ir stogo bei grindu sijų skerspjūviai parodyti 2.2 paveiksle. Skerspjūvių parametrai $b$ ir $h^{\prime}$ išlieka nepakitę visos optimizavimo metu, o keičiasi tik lentynų storiai $t_{f}$. Pradiniai lentynų storiai rèmo kolonoms yra $t_{f, \text { col }}^{0}=12 \mathrm{~mm}$, stogo sijoms $t_{f, \text { roof beam }}^{0}=8 \mathrm{~mm}$ ir grindu sijoms $t_{f, \text { floor beam }}^{0}=8 \mathrm{~mm}$. Pradiniai kolonų, stogo ir grindų sijų skerspjūvių plotai $\quad$ yra $\quad A_{\text {col }}^{0}=A_{1}^{0}=A_{2}^{0}=A_{3}^{0}=A_{4}^{0}=A_{5}^{0}=A_{6}^{0}=A_{7}^{0}=A_{8}^{0}=57,6 \mathrm{~cm}^{2}$, $A_{\text {roof beam }}^{0}=A_{9}^{0}=A_{10}^{0}=14,4 \mathrm{~cm}^{2}$ ir $A_{\text {floor beam }}^{0}=A_{11}^{0}=A_{12}^{0}=A_{13}^{0}=57 \mathrm{~cm}^{2}$, atitinkamai.

Pradinis rèmo tūris $V^{0}=279540 \mathrm{~cm}^{3}$. Skerspjūvio ribinès ịrąžos yra apskaičiuojamos pagal formules: $M_{0}=\sigma_{y} \cdot b \cdot t \cdot h^{\prime}=\sigma_{y} \cdot A \cdot \frac{h^{\prime}}{2}, \quad N_{0}=\sigma_{y} \cdot 2 b \cdot t=\sigma_{y} \cdot A$.

a)

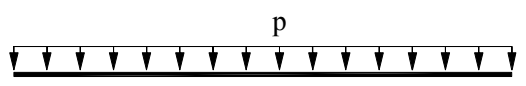

b)

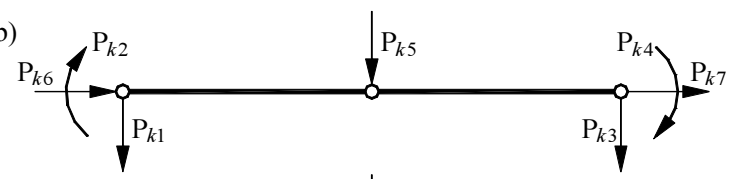

c)

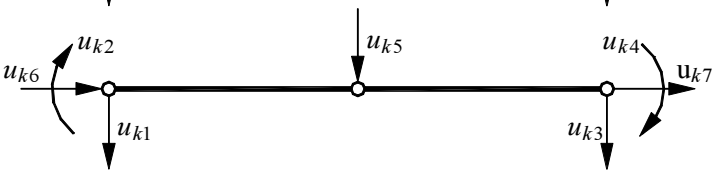

2.3 pav. Baigtinis elementas apkrautas tolygiai išskirstyta apkrova su vidurinio mazgo poslinkiu: a) išorinè apkrova; b) apibendrintos jègos c) mazginiai poslinkiai

Fig. 2.3. Finite element subjected by distributed load with linear displacements of central node: a) external load; b) generalised forces; c) nodal displacements

Pradinès kolonų ribinès įrąžos yra $M_{0, \text { col }}^{0}=155,66 \mathrm{kNm}$ ir $N_{0, \text { col }}^{0}=1353,6 \mathrm{kN}$, stogo ir grindu sijų atitinkamai $M_{0, \text { roof beam }}^{0}=30,456 \mathrm{kNm}$, 
$\begin{array}{llcl}N_{0, \text { roof beam }}^{0}=338,4 \mathrm{kN} & \text { ir } & M_{0, \text { floor beam }}^{0}=301,388 \mathrm{kNm} & \text { bei } \\ N_{0, \text { floor beam }}^{0}=1339,5 \mathrm{kN} ; \text { čia } c_{\text {col }}=0,115, c_{\text {floor beam }}=0,09, c_{\text {roof beam }}=0,225 .\end{array}$

Columns: $\begin{aligned} & b=240 \mathrm{~mm} \\ & h^{\prime}=230 \mathrm{~mm}\end{aligned}$

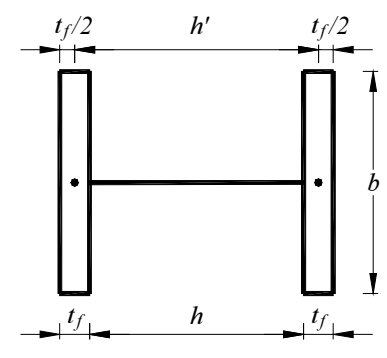

Roof beams: $\begin{aligned} & b=90 \mathrm{~mm} \\ & h^{\prime}=180 \mathrm{~mm}\end{aligned}$

Floor beams: $\begin{aligned} & b=190 \mathrm{~mm} \\ & h^{\prime}=450 \mathrm{~mm}\end{aligned}$

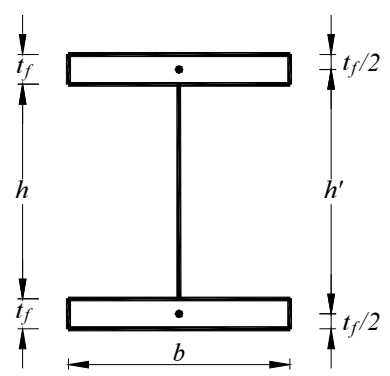

2.4 pav. Skerspjūviai

Fig. 2.4. Geometry of cross-sections

Kai liekamujju poslinkių apribojimų (2.27) nėra, gauti sekantys rezultatai: minimalus tūris $V_{\min }=156724 \mathrm{~cm}^{3}$; liekamieji sijų poslinkiai $u_{r 10}=0,088 \mathrm{~mm}$, $u_{r 11}=0,36 \mathrm{~mm}, u_{r 12}=0,77 \mathrm{~mm}, u_{r 22}=51,46 \mathrm{~mm}, u_{r 23}=12,62 \mathrm{~mm}$; plastinès deformacijos atsirado pjūviuose 7, 8, 14, 15, 20, 22, ir 29 (2.2 pav.).

Buvo išnagrinèti dar keturi uždavinio atvejai kai yra nustatyti liekamuju poslinkių $u_{r 22}, u_{r 23}$ apribojimai (2.2 pav.):

$$
\begin{gathered}
\mathbf{C} 1-6 \leq u_{r 22} \leq 6,-6 \leq u_{r 23} \leq 6 ; \\
\mathbf{C 2}-12 \leq u_{r 22} \leq 12,-12 \leq u_{r 23} \leq 12 ; \\
\mathbf{C 3}-18 \leq u_{r 22} \leq 18,-18 \leq u_{r 23} \leq 18 ; \\
\mathbf{C} 4-24 \leq u_{r 22} \leq 24,-24 \leq u_{r 23} \leq 24 .
\end{gathered}
$$

Poslinkių apribojimai įrašomi milimetrais. Minimalaus tūrio kitimas priklausomai nuo užduotų apribojimų parodytas 2.5 paveiksle. 


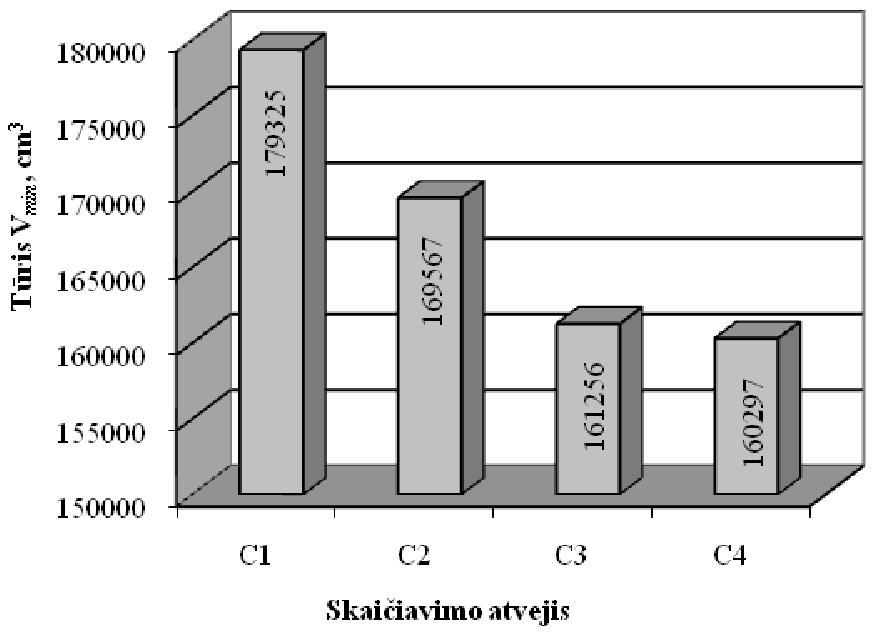

2.5 pav. Minimalus rèmo tūris $V_{\text {min }}$

Fig. 2.5. Variation of frame minimal volume $V_{\min }$

Liekamieji poslinkiai $u_{r 22}$ ir $u_{r 23}$, plastinès deformacijos ir skaičiuojamieji pjūviai, kuriuose atsivère plastiniai lankstai, kiekvienam skaičiavimo atvejui pateikti 2.1 lentelèje.

2.1 lentelè. Sijų liekamieji poslinkiai $u_{r i}$

Table 2.1. Residual displacements $u_{r i}$ of beams

\begin{tabular}{|c|c|c|c|}
\hline Skaičiavimo atvejai & $\begin{array}{c}u_{r 22}, \\
\mathrm{~mm}\end{array}$ & $\begin{array}{c}u_{r 23}, \\
\mathrm{~mm}\end{array}$ & $\begin{array}{c}\text { Pjūviai, kuriuose pasireiškè } \\
\text { plastinès deformacijos }\end{array}$ \\
\hline $\mathrm{C} 1$ & $\mathbf{6 , 0}$ & $\mathbf{6 , 0}$ & $7,8,14,20,22,29$ \\
\hline $\mathrm{C} 2$ & $\mathbf{1 2 , 0}$ & $\mathbf{1 2 , 0}$ & $8,14,15,20,22,29$ \\
\hline C3 & $\mathbf{1 8 , 0}$ & $\mathbf{1 8 , 0}$ & $7,8,14,15,20,22,29,30$ \\
\hline C4 & $\mathbf{2 4 , 0}$ & 14,48 & $7,8,14,15,20,22,29,30$ \\
\hline
\end{tabular}

\subsection{Patikrinamojo uždavinio matematinis modelis}

Prisitaikomumo būvio patikrinamasis uždavinys yra formuluojamas taip: esant pateiktam konstrukcijos ribiniu irražu vektoriui $\boldsymbol{S}_{0}$, ieškomos apkrovos kitimo 
ribos $\boldsymbol{F}_{\text {inf }}, \boldsymbol{F}_{\text {sup }}$, tenkinančios optimalumo kriteriju $\max \left(\boldsymbol{T}_{\text {inf }}^{T} \boldsymbol{F}_{\text {inf }}+\boldsymbol{T}_{\text {sup }}^{T} \boldsymbol{F}_{\text {sup }}\right)$ ir konstrukcijos prisitaikomumo bei standumo apribojamasias salygas.

Čia $\boldsymbol{T}_{\text {inf }}, \boldsymbol{T}_{\text {sup }}$ yra patikrinamojo kriterijaus svorio koeficientų vektoriai. Šią uždavinio formuluotę atitinka toks apkrovos kitimo ribų optimizavimo uždavinio matematinis modelis:

rasti

$$
\max \left(\boldsymbol{T}_{\text {sup }}^{T} \boldsymbol{F}_{\text {sup }}-\boldsymbol{T}_{\text {inf }}^{T} \boldsymbol{F}_{\text {inf }}\right)
$$

kai

$$
\begin{gathered}
\boldsymbol{\Phi} \boldsymbol{G} \lambda \leq \boldsymbol{S}_{0}-\boldsymbol{\Phi} \boldsymbol{S}_{e j}, \\
\lambda_{j}^{T}\left[\boldsymbol{S}_{0}-\boldsymbol{\Phi}\left(\boldsymbol{G} \lambda+\boldsymbol{S}_{e j}\right)\right]=0, \quad \lambda_{j} \geq \mathbf{0}, \\
\lambda=\sum_{j} \lambda_{j} \quad \text { visiems } \quad j \in J, \\
\boldsymbol{S}_{e j}=\alpha_{j}\left(\boldsymbol{F}_{\text {sup }}, \boldsymbol{F}_{\text {inf }}\right), \boldsymbol{F}_{\text {max }} \geq \boldsymbol{F}_{\text {sup }} \geq \mathbf{0}, \quad \boldsymbol{F}_{\text {min }} \geq \boldsymbol{F}_{\text {inf }} \geq \mathbf{0}, \\
\boldsymbol{u}_{r, \text { min }} \leq \boldsymbol{H} \lambda \leq \boldsymbol{u}_{r, \text { max }} .
\end{gathered}
$$

Tampraus skaičiavimo įrąžos $\boldsymbol{S}_{e j}$ yra apkrovos kitimo ribų $\boldsymbol{F}_{\text {sup }}, \boldsymbol{F}_{\text {inf }}$ funkcijos $\alpha_{j}$. Apkrovos ribų vektoriai $\boldsymbol{F}_{\text {inf }}, \boldsymbol{F}_{\text {sup }}$ ir plastinių daugiklių vektoriai $\lambda$ yra uždavinio (2.29)-(2.34) nežinomieji. Apribojamosios sąlygos (2.31) užtikrina konstrukcijos prisitaikomumą. Poslinkiai ribojami (2.34) analogiškai kaip ir konstrukcijos parametrų optimizavimo uždavinio matematiniame modelyje (2.22)-(2.27). Būvis, artimas ciklinei plastiškajai suirčiai, gaunamas tuomet, jei sąlygos (2.34) ignoruojamos.

\subsection{Patikrinamojo uždavinio pavyzdys}

Nagrinejjamas rèmas (2.6 pav.), kurio kolonoms naudojami HE ir rygeliui IPE tipo profiliai (2.2 lentelè), pagaminti iš plieno (takumo riba $\sigma_{y}=240 \mathrm{MPa}$, tamprumo modulis $E=2 \cdot 10^{5} \mathrm{MPa}$ ) ir yra veikiamas $\mathrm{KKA} \quad 0 \leq F_{1} \leq F_{1, \text { sup }}$, $0 \leq F_{2} \leq F_{2, \text { sup }}$. 


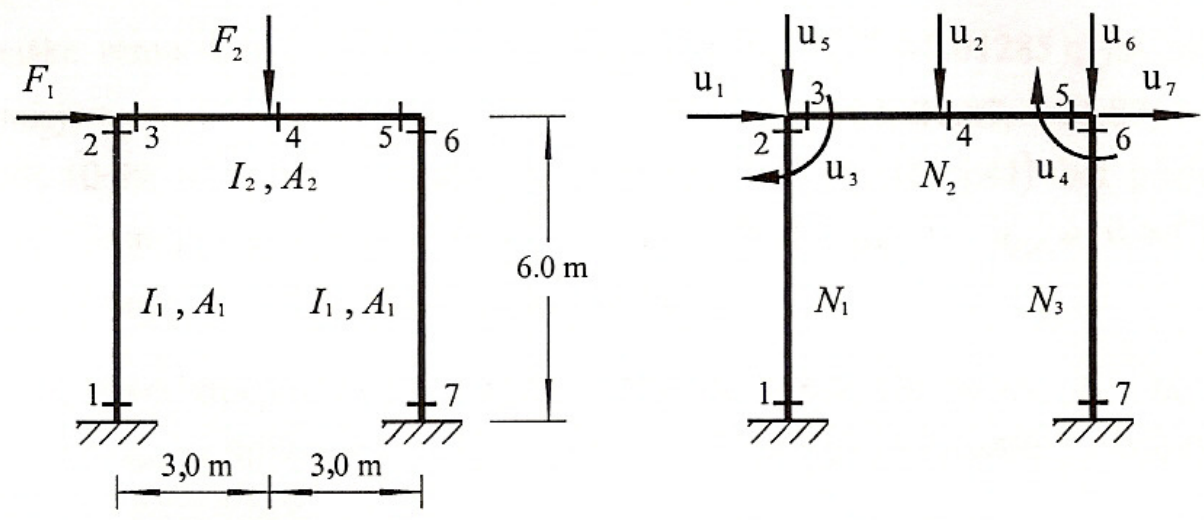

2.6 pav. Rèmo skaičiuojamoji schema ir jo diskretinis modelis

Fig. 2.6. Scheme of frame and discrete model

2.2 lentelè. Skerspjūvių charakteristikos

Table 2.2. Characteristics of cross-sections

\begin{tabular}{|c|c|c|}
\hline Charakteristika & HE240A & IPE400 \\
\hline$I \mathrm{~m}^{4}$ & $776,3 \cdot 10^{-7}$ & $231,3 \cdot 10^{-6}$ \\
\hline$A \mathrm{~m}^{2}$ & $7,684 \cdot 10^{-3}$ & $8,446 \cdot 10^{-3}$ \\
\hline$W_{p l} \mathrm{~m}^{3}$ & $744,6 \cdot 10^{-6}$ & $313,7 \cdot 10^{-5}$ \\
\hline$M_{0}=\sigma_{y} \cdot W_{p l} \mathrm{kNm}$ & 178,7 & 2027,04 \\
\hline$N_{0}=\sigma_{y} \cdot A \mathrm{kN}$ & 1844,16 & 0,15475 \\
\hline$c=\frac{M_{0}}{N_{0}} \mathrm{~m}$ & 0,0969 & \\
\hline
\end{tabular}

Patikrinamasis uždavinys $\max \left(F_{1, \text { sup }}+F_{2, \text { sup }}\right)$ sprendžiamas pagal matematini modeli (2.29)-(2.34). Šiuo atveju rèmo elementų skerspjūviai yra žinomi ir kolonoms naudojami HE240A, o rygeliui - IPE400.

Neivertinus standumo reikalavimu (6) gauta $F_{1, \text { sup }}^{*}=65,189 \mathrm{kN}$ ir $F_{2, \text { sup }}^{*}=281,64 \mathrm{kN}$ t.y. $\max \left(F_{1, \text { sup }}+F_{2, \text { sup }}\right)=346,8 \mathrm{kN}$. 


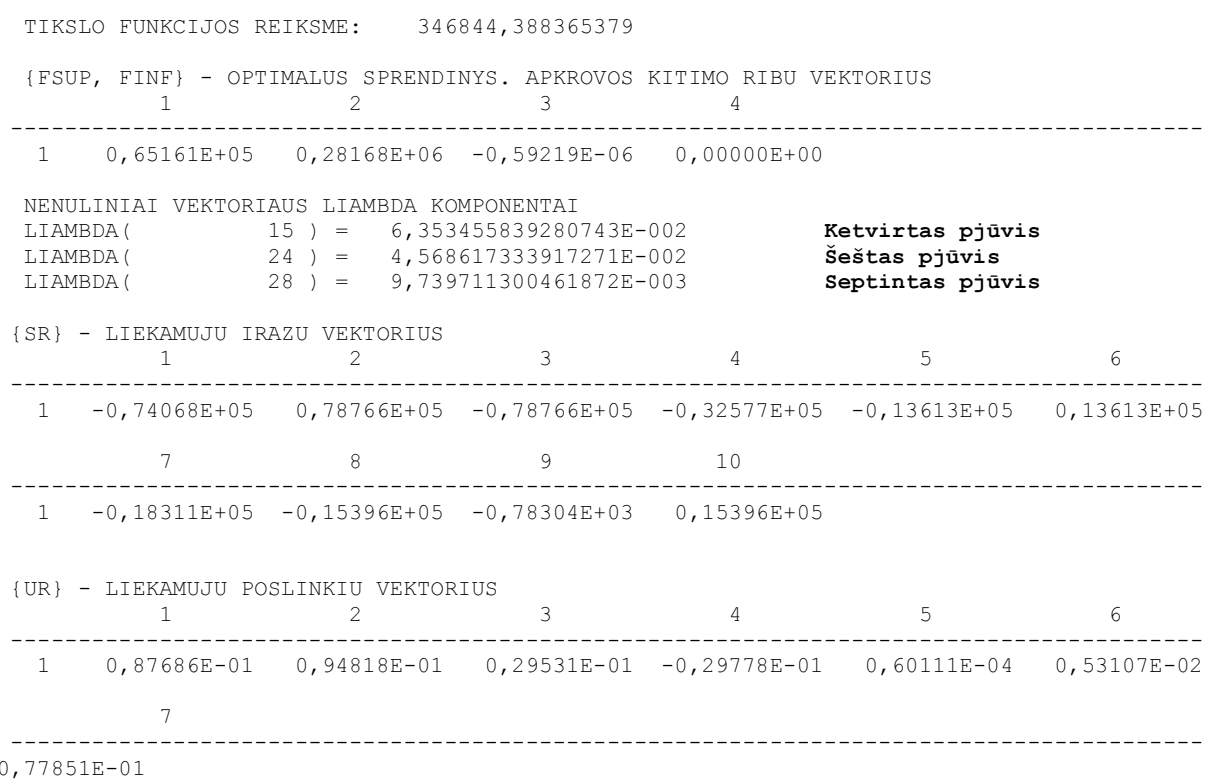

Ivertinus standumo reikalavimus $-\infty \leq u_{r, 1} \leq 20 \mathrm{~mm},-\infty \leq u_{r, 1} \leq 25 \mathrm{~mm}$, gauta $F_{1, \text { sup }}^{*}=67,802 \mathrm{kN}$ ir $F_{2, \text { sup }}^{*}=259,22 \mathrm{kN}\left(\max \left(F_{1, \text { sup }}+F_{2, \text { sup }}\right)=327,226 \mathrm{kN}\right)$.

\subsection{Antrojo skyriaus išvados}

1. Prisitaikiusios konstrukcijos analizès uždavinio matematinis modelis suponuoja naują teorinị teiginị: konstrukcija visada prisitaikys, jei analizės uždavinys (projektinis ar patikrinamasis) turi nors vieną leistinaji tašką.

2. Plastinis konstrukcijų skaičiavimas nuo apkrovų derinių turi būti grindžiamas prisitaikomumo teorija, igalinančia išvengti detalios apkrovimo istorijos nagrinejjimo.

3. Tiesioginio optimizavimo uždaviniai yra pagrindas pletoti diskretini optimizavima. 



\section{Prisitaikančiu konstrukciju optimizavimas projektavimo standartuose}

Prisitaikančių strypinių konstrukcijų optimalaus projektavimo aspektai, ivertinant stiprumo ir standumo sąlygas, yra išsamiai išnagrinèti (Maier 1969; König 1987; Atkočiūnas 1999, Tin-Loi 2000; Merkevičiūtè ir Atkočiūnas 2006). Tuo tarpu tampriujų plastinių rẻmų optimizavimo uždaviniuose klumpamosios galios sąlygų įvertinimas, kai apkrova kartotinè-kintamoji, ir dabartiniu metu lieka aktualia moksline problema. Pavyzdžiui, pagal EN1993 yra leidžiama projektuoti tampriuosius plastinius rèmus, tačiau čia nepilnai detalizuota metodika bei algoritmai prisitaikančių konstrukcijų klumpamosios galios ivertinimui. Šiame skyriuje nagrinejjami projektinio bei patikrinamojo uždavinių netiesiniai matematiniai modeliai, kuriuose yra įvertinami stiprumo, standumo ir klumpamosios galios apribojimai. Klumpamosios galios ivertinimui sukurta metodika ir algoritmai, apjungiantys komercini kompiuterini konstrukcijų projektavimo paketą MatrixFrame 4.1 su autoriu sukurtomis netiesiniu matematinio programavimo uždavinių sprendimo programomis. Visiems kitiems tyrejams tai suteikia galimybę netiesinio matematinio programavimo uždavinių sprendinius (liekamąsias irą̌zas ir liekamuosius poslinkius) integruoti i jų turimas konstrukcijų projektavimo programas. Skyriaus tematika paskelbti trys 
autoriaus straipsniai (Atkočiūnas et al. 2007a; Atkočiūnas ir Venskus 2008b, 2011).

\subsection{Apkrovų deriniai - kartotinès-kintamosios apkrovos viršūnès}

Pažymètina, jog apkrovų kombinacijos, kurios aktualios inžinerinejje praktikoje, gali būti modeliuojamos kaip atskiras KKA atvejis. Tarkime visu galimų apkrovu $\boldsymbol{F}_{j}$, kai $j=3$, kitimo ribų $\boldsymbol{F}_{j, \text { inf }}, \boldsymbol{F}_{j, \text { sup }}$ skaičius yra $p=2^{3}=8$. Tada apkrovos kitimo sritis (3.1 pav.) užrašoma $j$-mate prizme ABCDEFGI:
A) $\boldsymbol{F}_{1, \text { sup }}+\boldsymbol{F}_{2, \text { sup }}+\boldsymbol{F}_{3, \text { sup }}$;
B) $\boldsymbol{F}_{1, \text { sup }}+\boldsymbol{F}_{2, \text { sup }}+\boldsymbol{F}_{3, \text { inf }}$;
C) $\boldsymbol{F}_{1, \text { sup }}+\boldsymbol{F}_{2, \text { inf }}+\boldsymbol{F}_{3, \text { inf }}$;
D) $\boldsymbol{F}_{1, \text { sup }}+\boldsymbol{F}_{2, \text { inf }}+\boldsymbol{F}_{3, \text { sup }}$;
E) $\boldsymbol{F}_{1, \text { inf }}+\boldsymbol{F}_{2, \text { sup }}+\boldsymbol{F}_{3, \text { sup }}$;
F) $\boldsymbol{F}_{1, \text { inf }}+\boldsymbol{F}_{2, \text { sup }}+\boldsymbol{F}_{3, \text { inf }}$;
G) $\boldsymbol{F}_{1, i n f}+\boldsymbol{F}_{2, i n f}+\boldsymbol{F}_{3, \text { inf }}$;
I) $\boldsymbol{F}_{1, \text { inf }}+\boldsymbol{F}_{2, \text { inf }}+\boldsymbol{F}_{3, \text { sup }}$;

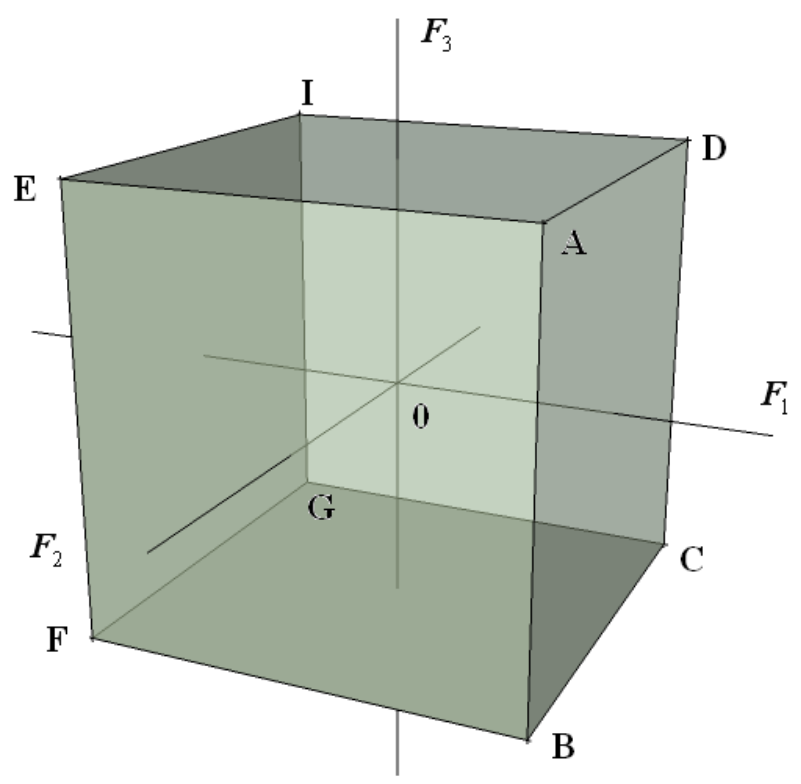

3.1 pav. KKA kitimo sritis

Fig. 3.1. Repeated variable load variation domain 
Kiekviena apkrova $\boldsymbol{F}_{j}$ laike $t$ gali kisti tarp savo ribų $\boldsymbol{F}_{j, \text { inf }}, \boldsymbol{F}_{j, \text { sup }}$. Pavyzdžiui apkrova $\boldsymbol{F}_{1}$ gali aprašyti vèją (3.1 lentelè).

3.1 lentelè. Apkrovos $\boldsymbol{F}_{1}, \boldsymbol{F}_{2}, \boldsymbol{F}_{3}$

Table 3.1. Loads $\boldsymbol{F}_{1}, \boldsymbol{F}_{2}, \boldsymbol{F}_{3}$

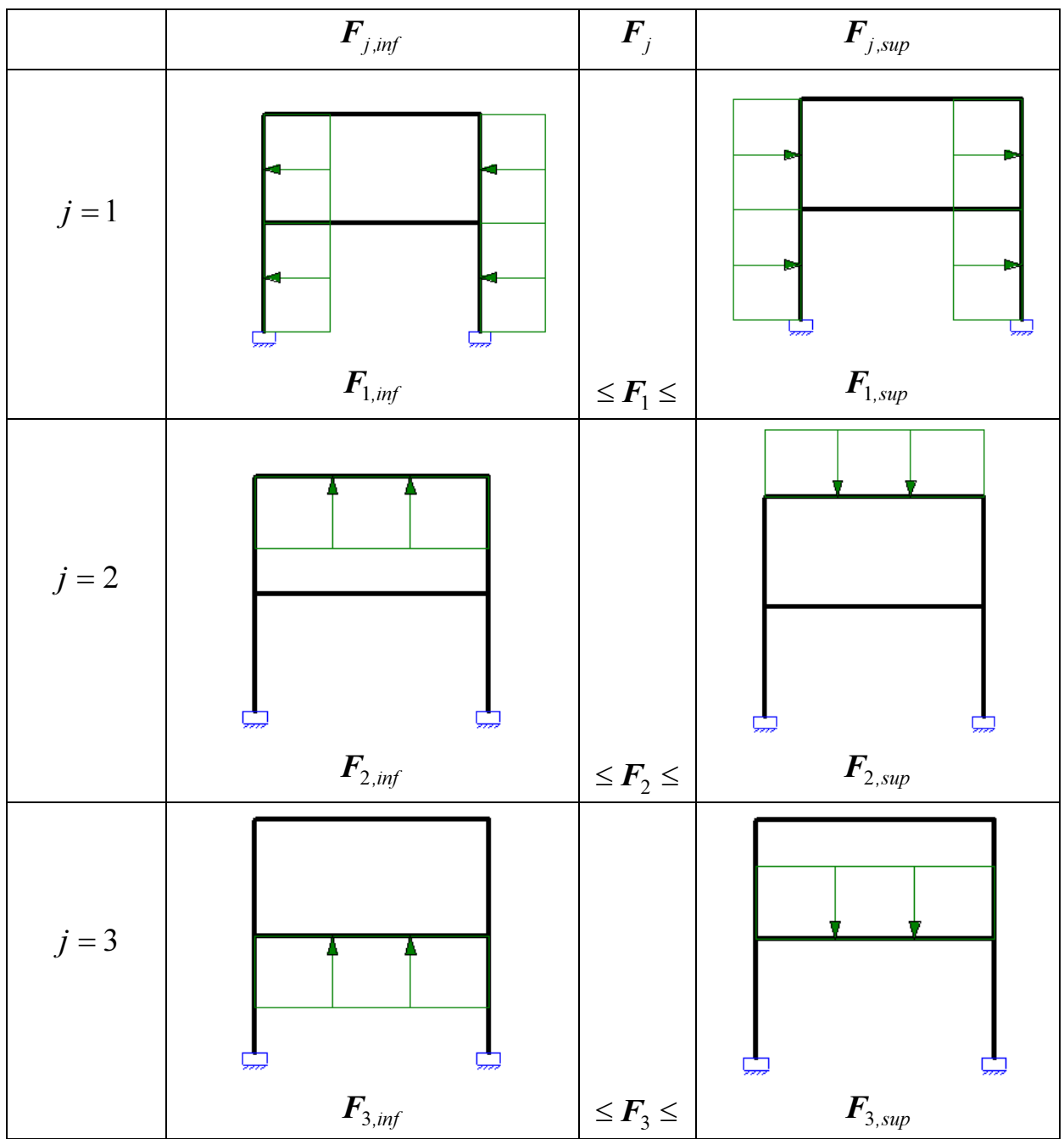


Tokių atveju apkrovos kitimo ribos $\boldsymbol{F}_{1, \text { inf }}$ reiškia maksimalią galimą vèjo apkrovą iš konstrukcijos dešinès pusès , o $\boldsymbol{F}_{1, \text { sup }}$ - maksimalią galimą vejo apkrovą iš konstrukcijos kairès pusès . Analogiškai $\boldsymbol{F}_{2}$ gali aprašyti sniego apkrovą, kur $\boldsymbol{F}_{2, \text { inf }}$ yra maksimali galima sniego apkrova iš konstrukcijos apačios ir $\boldsymbol{F}_{2, \text { sup }}-$ maksimali galima sniego apkrova iš konstrukcijos viršaus. Be abejo, apkrova $\boldsymbol{F}_{2, \text { inf }}$ negalima, tačiau čia paminèta dèl matematinio formalumo. Kai apkrova negalima, visada jos ribą galime prilyginti nuliui. Trečioji apkrova $\boldsymbol{F}_{3}$ gali aprašyti naudingą apkrovą. Tada $\boldsymbol{F}_{3, \text { inf }}$ reikš naudingą apkrovą iš apačios (vèlgi nelabai imanoma), bei $\boldsymbol{F}_{3, \text { sup }}$ - naudinga apkrova iš viršaus. Tokiu būdu galima ivertinti kiek norima ivvairių apkrovų. Apkrovų kombinacijos per apkrovos viršūnes, ivvedus papildomus daugiklius, užrašomos sekančiai:

1) $k_{11} \boldsymbol{F}_{1, \text { sup }}+k_{12} \boldsymbol{F}_{2, \text { sup }}+k_{13} \boldsymbol{F}_{3, \text { sup }}$,

2) $k_{21} \boldsymbol{F}_{1, \text { sup }}+k_{22} \boldsymbol{F}_{2, \text { sup }}+k_{23} \boldsymbol{F}_{3, \text { inf }}$,

3) $k_{31} \boldsymbol{F}_{1, \text { sup }}+k_{32} \boldsymbol{F}_{2, \text { inf }}+k_{33} \boldsymbol{F}_{3, \text { inf }}$,

4) $k_{41} \boldsymbol{F}_{1, \text { sup }}+k_{42} \boldsymbol{F}_{2, \text { inf }}+k_{42} \boldsymbol{F}_{3, \text { sup }}$,

5) $k_{51} \boldsymbol{F}_{1, \text { inf }}+k_{52} \boldsymbol{F}_{2, \text { sup }}+k_{53} \boldsymbol{F}_{3, \text { sup }}$,

6) $k_{61} \boldsymbol{F}_{1, \text { inf }}+k_{62} \boldsymbol{F}_{2, \text { sup }}+k_{63} \boldsymbol{F}_{3, \text { inf }}$,

7) $k_{71} \boldsymbol{F}_{1, \text { inf }}+k_{72} \boldsymbol{F}_{2, \text { inf }}+k_{73} \boldsymbol{F}_{3, \text { inf }}$,

8) $k_{81} \boldsymbol{F}_{1, \text { inf }}+k_{82} \boldsymbol{F}_{2, \text { inf }}+k_{83} \boldsymbol{F}_{3, \text { sup }}$.

kai daugiklių (apkrovų kombinacijų koeficientu) reikšmės $k_{11}, k_{12}, \ldots, k_{83}$ bei apkrovų kitimo ribos $\boldsymbol{F}_{j, \text { inf }}, \boldsymbol{F}_{j, \text { sup }}$ nustatomos pagal nacionalinių standartų reikalavimus. Jei tam tikros apkrovos pagal standartu reikalavimus yra nesuderinamos (pavyzdžiui sniegas ir vejjas) tai koeficientas prie nesuderinamos apkrovos yra prilyginamas nuliui. Apkrovų kitimo ribos gali būti nustatomos pagal inžinieriams parengtas reikšmes, kurias galima rasti standartų lentelèse, arba panaudojant statistinius skaičiavimus. Pavyzdžiui, vejo arba sniego ribines apkrovas galima nustatyti pagal tam tikro regiono meteorologinius duomenis. Tokiu būdu KKA iqvertina ir statistinę apkrovos prigimti. 


\subsection{Judama apkrova - atskiras kartotinès- kintamosios apkrovos atvejis}

Vienas iš apkrovų tipų yra judama apkrova. Ji aktuali potiltinèms sijoms (pramonès pastatuose) arba santvaroms sudarančioms tiltų konstrukcijas. Judama apkrova gali būti modeliuojama vienu, dviem arba keletu koncentruotų jègų. Pavyzdžiui, judama apkrova sudaryta iš dviejų koncentruotų jègų poros $\boldsymbol{F}_{A}$ ir $\boldsymbol{F}_{B}$ (3.1 pav., a) veikia apatinę santvaros (3.1 pav., b) dali.

a)

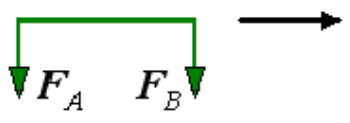

b)

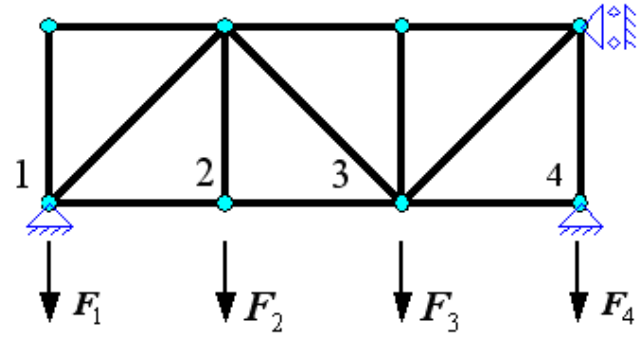

c)

(1)
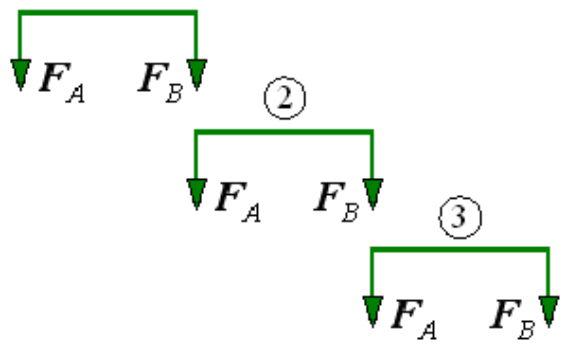

3.2 pav. Judama apkrova išreikšta per KKA

Fig. 3.2. Moving load in terms of repeated variable load

Judama apkrova santvaros apatinèje juostoje gali užimti padètis 1, 2 arba 3 (3.1 pav., c).

Kai santvara (3.1 pav., b) apkrauta KKA, kur kiekviena iš jejgu $\boldsymbol{F}_{j}$, kai $j=4$, gali kisti tarp apkrovos kitimo ribų $\boldsymbol{F}_{j, \text { inf }}, \boldsymbol{F}_{j, \text { sup }}$. Apkrovų viršūnių skaičius $p=2^{4}=16$ : 

1) $\boldsymbol{F}_{1, \text { sup }}+\boldsymbol{F}_{2, \text { sup }}+\boldsymbol{F}_{3, \text { sup }}+\boldsymbol{F}_{4, \text { sup }}$, 2) $\boldsymbol{F}_{1, \text { sup }}+\boldsymbol{F}_{2, \text { sup }}+\boldsymbol{F}_{3, \text { sup }}+\boldsymbol{F}_{4, \text { inf }}$,
3) $\boldsymbol{F}_{1, \text { sup }}+\boldsymbol{F}_{2, \text { sup }}+\boldsymbol{F}_{3, \text { inf }}+\boldsymbol{F}_{4, \text { sup }}$, 4) $\boldsymbol{F}_{1, \text { sup }}+\boldsymbol{F}_{2, \text { sup }}+\boldsymbol{F}_{3, \text { inf }}+\boldsymbol{F}_{4, \text { inf }}$,
5) $\boldsymbol{F}_{1, \text { sup }}+\boldsymbol{F}_{2, \text { inf }}+\boldsymbol{F}_{3, \text { sup }}+\boldsymbol{F}_{4, \text { sup }}$, 6) $\boldsymbol{F}_{1, \text { sup }}+\boldsymbol{F}_{2, \text { inf }}+\boldsymbol{F}_{3, \text { sup }}+\boldsymbol{F}_{4, \text { inf }}$,
7) $\left.\boldsymbol{F}_{1, \text { sup }}+\boldsymbol{F}_{2, \text { inf }}+\boldsymbol{F}_{3, \text { inf }}+\boldsymbol{F}_{4, \text { sup }}, 8\right) \boldsymbol{F}_{1, \text { sup }}+\boldsymbol{F}_{2, \text { inf }}+\boldsymbol{F}_{3, \text { inf }}+\boldsymbol{F}_{4, \text { inf }}$,
9) $\left.\boldsymbol{F}_{1, \text { inf }}+\boldsymbol{F}_{2, \text { sup }}+\boldsymbol{F}_{3, \text { sup }}+\boldsymbol{F}_{4, \text { sup }}, 10\right) \boldsymbol{F}_{1, \text { inf }}+\boldsymbol{F}_{2, \text { sup }}+\boldsymbol{F}_{3, \text { sup }}+\boldsymbol{F}_{4, \text { inf }}$,
11) $\left.\boldsymbol{F}_{1, \text { inf }}+\boldsymbol{F}_{2, \text { sup }}+\boldsymbol{F}_{3, \text { inf }}+\boldsymbol{F}_{4, \text { sup }}, 12\right) \boldsymbol{F}_{1, \text { inf }}+\boldsymbol{F}_{2, \text { sup }}+\boldsymbol{F}_{3, \text { inf }}+\boldsymbol{F}_{4, \text { inf }}$,
13) $\left.\boldsymbol{F}_{1, \text { inf }}+\boldsymbol{F}_{2, \text { inf }}+\boldsymbol{F}_{3, \text { sup }}+\boldsymbol{F}_{4, \text { sup }}, 14\right) \boldsymbol{F}_{1, \text { inf }}+\boldsymbol{F}_{2, \text { inf }}+\boldsymbol{F}_{3, \text { sup }}+\boldsymbol{F}_{4, \text { inf }}$,
15) $\left.\boldsymbol{F}_{1, \text { inf }}+\boldsymbol{F}_{2, \text { inf }}+\boldsymbol{F}_{3, \text { inf }}+\boldsymbol{F}_{4, \text { sup }}, 16\right) \boldsymbol{F}_{1, \text { inf }}+\boldsymbol{F}_{2, \text { inf }}+\boldsymbol{F}_{3, \text { inf }}+\boldsymbol{F}_{4, \text { inf }}$.

Ivertinus, $\operatorname{kad} \boldsymbol{F}_{j, \text { inf }}=0, j=1, \ldots, 4$ (judama apkrova negali veikti iš apačios i viršu), bei tai, jog judama apkrova veikia tik dviejuose gretimuose apatinès santvaros juostos mazguose iš šešiolikos apkrovos viršūnių lieka trys:
1) $\boldsymbol{F}_{1, \text { sup }}+\boldsymbol{F}_{2, \text { sup }}$,
2) $\boldsymbol{F}_{2, \text { sup }}+\boldsymbol{F}_{3, \text { sup }}$,
3) $\boldsymbol{F}_{3, \text { sup }}+\boldsymbol{F}_{4, \text { sup }}$.

Ivertinus judamos apkrovos reikšmes $\boldsymbol{F}_{\max A B}=\max \left(\boldsymbol{F}_{A}, \boldsymbol{F}_{B}\right)$ gaunamos tokios apkrovos kitimo ribos:
1) $0 \leq \boldsymbol{F}_{1, \text { sup }} \leq \boldsymbol{F}_{\max A B}$,
2) $0 \leq \boldsymbol{F}_{2, \text { sup }} \leq \boldsymbol{F}_{\max A B}$,
3) $0 \leq \boldsymbol{F}_{3, \text { sup }} \leq \boldsymbol{F}_{\max A B}$,
4) $0 \leq \boldsymbol{F}_{4, \text { sup }} \leq \boldsymbol{F}_{\max A B}$,

Taigi kaip matome iš pastarujų formulių judamos apkrovos deriniai yra poaibis KKA t. y. judama apkrova gali būti užrašoma per KKA viršūnes. 


\subsection{Vienkarte apkrova - atskiras kartotinès- kintamosios apkrovos atvejis}

Kai konstrukcija yra veikiama vienkartes apkrovos $\boldsymbol{F}_{\text {mon }}$ (3.3 pav.) ją taip pat galima aprašyti kaip KKA. Tokiu atveju apkrova $\boldsymbol{F}_{\text {mon }}$ užrašoma per kintamą apkrovą $\boldsymbol{F}, \boldsymbol{F}_{\text {inf }} \leq \boldsymbol{F} \leq \boldsymbol{F}_{\text {sup }}$, kur priimama, kad apkrovos $\boldsymbol{F}$ kitimo ribos sutampa ties reikšme $\boldsymbol{F}_{\text {mon }}$ t. y. $\boldsymbol{F}_{\text {inf }}=\left[\boldsymbol{F} \equiv \boldsymbol{F}_{\text {mon }}\right]=\boldsymbol{F}_{\text {sup }}$ (galima užrašyti ir kitaip: $\left.\boldsymbol{F}_{\text {inf }}=\boldsymbol{F}_{\text {sup }}=\boldsymbol{F}_{\text {mon }}\right)$.

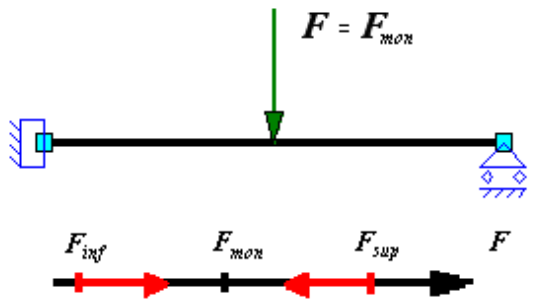

3.3 pav. Vienkartė apkrova išreikšta per KKA

Fig. 3.3. Monotonically increasing load in terms of repeated variable load

Taigi vienkartė apkrova gali būti užrašoma per KKA, t. y. vienkartė apkrova yra atskiras KKA atvejis. Projektinio (2.22)-(2.27) ir patikrinamojo (2.29)-(2.34) uždavinių matematiniai modeliai vienkartès apkrovos atvejui parodyti 3.2 lentelëje.

3.2 lentelè. Optimizavimo matematiniai modeliai vienkartės apkrovos atveju

Table 3.2. Optimization mathematical models in case of monotonically increasing load

\begin{tabular}{|c|c|}
\hline Projektinis uždavinys & Patikrinamasis uždavinys \\
\hline $\min \left(\boldsymbol{L}^{T} \boldsymbol{S}_{0}+\lambda^{T} \varphi\right)$ & rasti $\quad \max \left(\boldsymbol{T}^{T} \boldsymbol{F}-\lambda^{T} \varphi\right)$, \\
\hline kai & kai \\
\hline$\varphi=\Gamma \boldsymbol{S}_{0}-\boldsymbol{\Phi}\left(\boldsymbol{G} \lambda+\boldsymbol{S}_{e}\right) \geq \mathbf{0}$ & $\varphi=\boldsymbol{S}_{0}-\boldsymbol{\Phi}\left(\boldsymbol{G} \lambda+\boldsymbol{S}_{e}\right) \geq \mathbf{0}$, \\
\hline$\lambda \geq \mathbf{0}$ & $\lambda \geq \mathbf{0}$ \\
\hline $\boldsymbol{S}_{\min } \leq \boldsymbol{S}_{0} \leq \boldsymbol{S}_{\max }$ & $\mathbf{0} \leq \boldsymbol{F} \leq \boldsymbol{F}_{m o n}$ \\
\hline $\boldsymbol{u}_{\min } \leq\left(\boldsymbol{u}_{r}+\boldsymbol{u}_{e}\right) \leq \boldsymbol{u}_{\max }$ & $\boldsymbol{u}_{\min } \leq\left(\boldsymbol{u}_{r}+\boldsymbol{u}_{e}\right) \leq \boldsymbol{u}_{\max }$. \\
\hline
\end{tabular}




\subsection{Stiprumo, standumo ir klumpamosios galios ivertinimas optimizavimo uždaviniuose}

Pagrindinis inžinierinis tikslas projektuojant konstrukcijas yra stiprumo, standumo ir klumpamosios galios reikalavimų užtikrinimas (Žiliukas 2004, Čižas 1993). Taipogi šalia paminètų reikalavimų konstrukcija turi būti optimali t. y. jos kaina turi būti minimali. Kitas aktualus uždavinys renovuojant konstrukcijas, yra laikomosios galios patikra, kurios metu reikia nustatyti ar konstrukcija gebės atlaikyti tam tikra papildoma apkrovą (pavyzdžiui jei bus pristatytas papildomas pastato aukštas), kuri nepažeis stiprumo standumo ir klumpamosios galios reikalavimų. Konstrukciju projektavimas yra atliekamas laikantis projektavimo standartų reikalavimų. Šiame poskyryje bus parodyta kaip optimizavimo uždaviniuose yra ivertinamas stiprumas, standumas ir klumpamoji galia laikantis projektavimo standartų reikalavimų.

\subsubsection{Optimizavimo uždavinių matematiniai modeliai}

Projektinio uždavinio matematinis modelis (2.22)-(2.27) praktiniam uždavinių sprendimui yra užrašomas:

rasti

$$
\min \left(\boldsymbol{L}^{T} \boldsymbol{S}_{0}+\lambda_{j}^{T} \boldsymbol{\varphi}_{j}\right)
$$

kai

$$
\begin{gathered}
\boldsymbol{\varphi}_{j}=\boldsymbol{\Gamma} \boldsymbol{S}_{0}-\boldsymbol{\Phi}\left(\boldsymbol{G} \lambda+\boldsymbol{S}_{e j}+\boldsymbol{S}_{e c}\right) \geq \mathbf{0}, \\
\lambda_{j} \geq \mathbf{0}, \lambda=\sum_{j} \lambda_{j}, j \in J, \\
\boldsymbol{S}_{\text {min }} \leq \boldsymbol{S}_{0} \leq \boldsymbol{S}_{\max } ; \\
\boldsymbol{u}_{\text {min }} \leq\left(\boldsymbol{u}_{r}+\boldsymbol{u}_{e j}+\boldsymbol{u}_{e c}\right) \leq \boldsymbol{u}_{\max } .
\end{gathered}
$$

Apkrovos optimizavimo uždavinys (2.29)-(2.34) užrašomas sekančiai:

rasti

$$
\max \left(\boldsymbol{T}_{\text {sup }}^{T} \boldsymbol{F}_{\text {sup }}-\boldsymbol{T}_{i n f}^{T} \boldsymbol{F}_{i n f}-\lambda_{j}^{T} \boldsymbol{\varphi}_{j}\right),
$$


kai

$$
\begin{gathered}
\boldsymbol{\varphi}_{j}=\boldsymbol{S}_{0}-\boldsymbol{\Phi}\left(\boldsymbol{G} \lambda+\boldsymbol{S}_{e j}+\boldsymbol{S}_{e c}\right) \geq \mathbf{0}, \\
\lambda_{j} \geq \mathbf{0}, \lambda=\sum_{j} \lambda_{j}, j \in J, \\
\mathbf{0} \leq \boldsymbol{F}_{\text {sup }} \leq \boldsymbol{F}_{\max }, \boldsymbol{F}_{\text {min }} \leq \boldsymbol{F}_{i n f} \leq \mathbf{0} ; \\
\boldsymbol{u}_{\text {min }} \leq\left(\boldsymbol{u}_{r}+\boldsymbol{u}_{e j}+\boldsymbol{u}_{e c}\right) \leq \boldsymbol{u}_{\max } .
\end{gathered}
$$

Matematiniuose modeliuose vektorius $\boldsymbol{S}_{e c}$ išreiškia tamprias irą̌žas nuo pastovios apkrovos $\boldsymbol{F}_{c}$ (pavyzdžiui, nuosavas konstrukcijų svoris), bei atitinkamai $\boldsymbol{u}_{e c}$ reiškia tamprius poslinkius nuo pastovios apkrovos $\boldsymbol{F}_{c}$.

Labai naudingas matematinis irankis tiesiniam ir netiesiniam matematiniam programavimui yra Lagranžo apribojimų atlaisvinimas (lagrangian relaxation) (Ravindra et al. 1993, Bertsekas 2003). Šio metodo esmè ta, kad sudettingus apribojimus, apsunkinančius optimizavimo procesa, padaugintus iš neneigiamuc daugikliu galima nukelti $\mathfrak{i}$ tikslo funkciją. Optimaliame plane neneigiami daugikliai igauna Langranžo daugiklių prasmę, o nukeltujų apribojimų sandauga su jais atitinka matematinio griežtumo salygą arba kitaip tariant matematinio griežtumo salyga yra nukeliama i tikslo funkciją. Šis metodas yra igyvendintas matematiniuose modeliuose (3.1)-(3.5) ir (3.6)-(3.10). Optimizavimas tokiu atveju vyksta efektyviau, nes kiekvieno optimizavimo žingsnio metu nereikalaujama tenkinti matematinio griežtumo sąlygos, kuri turi būti tenkinama tik optimaliame plane.

Matematiniame modelyje (3.1)-(3.5) pradiniai skerspjūviai turi būti parinkti tokie, kad tenkintųsi sąlyga $(3,5)$ t. y. tamprūs poslinkiai turi neišeiti iš užsiduotų maksimalių poslinkių ribų $\boldsymbol{u}_{\min }$ ir $\boldsymbol{u}_{\max }$.

\subsubsection{Klumpamosios galios skaičiavimas pagal EN1993 projektavimo standartą}

EN1993 projektavimo standarto atveju strypu klumpamoji galia skaičiuojama pagal projektavimo standarto formules:

$$
\begin{aligned}
& \frac{N_{E d}}{N_{b, R d}} \leq 1.0, \\
& \frac{M_{E d}}{M_{b, R d}} \leq 1.0,
\end{aligned}
$$




$$
\begin{aligned}
& \frac{N_{E d}}{\frac{\chi_{y} N_{R k}}{\gamma_{M 1}}}+k_{y y} \frac{M_{y, E d}+\Delta M_{y, E d}}{\chi_{L T} \frac{M_{y, R k}}{\gamma_{M 1}}}+k_{y z} \frac{M_{z, E d}+\Delta M_{z, E d}}{\frac{M_{z, R k}}{\gamma_{M 1}}} \leq 1, \\
& \frac{N_{E d}}{\frac{\chi_{z} N_{R k}}{\gamma_{M 1}}}+k_{z y} \frac{M_{y, E d}+\Delta M_{y, E d}}{\chi_{L T} \frac{M_{y, R k}}{\gamma_{M 1}}}+k_{z z} \frac{M_{z, E d}+\Delta M_{z, E d}}{\frac{M_{z, R k}}{\gamma_{M 1}}} \leq 1,
\end{aligned}
$$

čia $y-y$ - juostoms lygiagreti skerspjūvio ašis; $z-z$ - juostoms statmena skerspjūvio ašis; $N_{E d}$-skaičiuotinè gniuždomosios jègos reikšmė; $N_{b, R d}$ - skaičiuotinè gniuždomojo elemento klumpamoji galia; $M_{E d}$ - skaičiuotinė momento reikšmé; $M_{b, R d}$ - skaičiuotinè lenkiamosios klupumo galios reikšmè.

$N_{E d}, M_{y, E d}$ ir $M_{z, E d}$ - skaičiuotinès gniuždomosios jègos ir didžiausiujuc momentų atitinkamai aplink y-y ir z-z ašis išilgai elemento reikšmės; $\Delta M_{y, E d}$, $\Delta M_{z, E d}$ - momentai, susidarantys dèl sunkio centro ašies poslinkio pagal EN1993\#6.2.9.3 nuostatas 4 klasès skerspjūviams, žr. EN1993\#6.7 lentelę; $\chi_{y}$ ir $\chi_{z}$ - lenkiamojo klupumo koeficientai pagal EN1993\#6.3.1; $N_{R k}$ - charakteristinè ašinè kritinio skerspjūvio gniuždomoji galia; $M_{y, R k}, M_{z, R k}$ - charakteristinès kritinio skerspjūvio lenkiamosios galios atitinkamai aplink y-y ir z-z ašis išilgai elemento reikšmès; $\chi_{L T}$ - skersinio-sukamojo klupumo koeficientas pagal EN1993\#6.3.2; $k_{y y}, k_{y z}, k_{z y}, k_{z z}$ - sąveikos koeficientai; $\gamma_{M 1}-$ dalinis elementų klupumo laikomosios galios koeficientas.

Formulè (3.11) įvertina tik ašinio gniuždymo elemento klumpamają galia, o (3.12) - tik lenkiamojo elemento klumpamaja galia. Elementai, kuriuos kartu veikia lenkimas ir ašinis gniuždymas turi atitikti formulių (3.13) ir (3.14) reikalavimus. Plastinès deformacijos klumpamosios galios skaičiavimo formulèse ivertinamos per charakteristines kritinio skerspjūvio lenkiamosios galios $M_{y, R k}$, $M_{z, R k}$ reikšmes kurios išreiškia ribinius lenkimo momentus apie y-y ir z-z ašis. O liekamosios i̇ražos îvertinamos per $N_{E d}, M_{y, E d}$ ir $M_{z, E d}$ t. y. per sumini poveiki (suma tampriujuc ir liekamujų irą̧žu): $N_{E d}=N_{e}+N_{r}$, $M_{y, E d}=M_{y, e}+M_{y, r}$ ir $M_{z, E d}=M_{z, e}+M_{z, r}$. 


\subsubsection{Klumpamosios galios skaičiavimas pagal NEN6771 projektavimo standartą}

Klumpamoji galia pagal projektavimo standartą NEN6771 apskaičiuojama pagal formules:

$$
\begin{gathered}
\frac{N_{c ; s ; d}}{\omega_{z ; b u c} N_{c ; u ; d}} \leq 1, \\
\frac{N_{c ; s ; d}}{\omega_{y ; b u c} N_{c ; u ; d}} \leq 1, \\
\frac{M_{y ; m a x ; s ; d}}{\omega_{k i p} M_{y ; u ; d}} \leq 1, \\
\frac{N_{c ; s ; d}}{N_{c ; u ; d}}+\frac{n_{y}}{n_{y}-1} \frac{M_{y ; e q u ; s ; d}+F_{y ; t o t ; s ; d} e_{y}^{*}}{\omega_{k i p} M_{y ; u ; d}}+\frac{n_{z}}{n_{z}-1} \frac{\chi_{y} M_{z ; e q u ; s ; d}}{M_{z ; u ; d}} \leq 1, \\
\frac{N_{c ; s ; d}}{N_{c ; u ; d}}+\frac{n_{y}}{n_{y}-1} \frac{\chi_{z} M_{y ; e q u ; s ; d}}{\omega_{k i p} M_{y ; u ; d}}+\frac{n_{z}}{n_{z}-1} \frac{M_{z ; e q u ; s ; d}+F_{z ; t o t ; s ; d} e_{z}^{*}}{M_{z ; u ; d}} \leq 1,
\end{gathered}
$$

čia $y-y$ - juostoms lygiagreti skerspjūvio ašis; $z-z$ - juostoms statmena skerspjūvio ašis; $N_{c ; s ; d}$ - skaičiuotinė gniuždomosios jègos reikšmė; $N_{c ; u ; d}$ - skaičiuotinè ašinè skerspjūvio gniuždomoji galia; $\omega_{y ; b u c}, \omega_{z ; b u c}-$ klupumo koeficientai atitinkamai aplink y-y ir z-z ašis, žr. NEN6771\#12.1.1.4; $M_{y ; m a x ; s ; d}-$ skaičiuotinè lenkiamojo momento reikšmė; $M_{y ; u ; d}, M_{z ; u ; d}-$ skaičiuotinè lenkiamoji galia; $\omega_{k i p}$ - klupumo koeficientas; $n_{y}, n_{z}$ - proporcijos koeficientai; $M_{y ; e q u ; s ; d}, M_{z ; e q u ; s ; d}$ - ekvivalentinès skaičiuotinès lenkiamojo momento reikšmès atitinkamai aplink y-y ir z-z ašis; $F_{y ; t o t ; s ; d}, F_{z ; t t o ; s ; d}$ - skaičiuotinès suminès gniuždomosios apkrovos reikšmès; $e_{y}^{*}, e_{z}^{*}-$ ekscentricitetai atitinkamai y-y ir z-z ašies atžvilgiu; $\chi_{y}, \chi_{z}$ - koeficientai priklausantys nuo nagrinèjamos konstrukcijos konfigūracijos; 
Formulès (3.15) ir (3.16) ìvertina tik ašinio gniuždymo elemento klumpamają galia y-y ir z-z ašių atžvilgiu, atitinkamai, o (3.17) - tik lenkiamojo elemento klumpamają galia. Elementai, kuriuos kartu veikia lenkimas ir ašinis gniuždymas turi atitikti formulių (3.18) ir (3.19) reikalavimus. Analogiškai EN1993, plastinès deformacijos NEN6771 standarte klumpamosios galios skaičiavimo formulèse ịvertinamos per charakteristines kritinio skerspjūvio lenkiamosios galios $M_{y ; u ; d}, M_{z ; u ; d}$ reikšmes kurios išreiškia ribinius lenkimo momentus apie y-y ir z-z ašis. O liekamosios įražos įvertinamos per skaičiuotines ašinès jègos bei lenkimo momentų reikšmes: $N_{c ; s ; d}, M_{y ; m a x ; s ; d}, M_{y ; e q u ; s ; d}$ ir $M_{z ; e q u ; s ; d}$.

\subsubsection{Klumpamosios galios ivertinimo algoritmas optimizavimo uždaviniuose}

Inžinieriniu poreikiu igyvendinimui yra sukurta daug projektavimo standartus realizuojančių komercinių kompiuterinių programų. Šiame skyriuje aprašytam klumpamosios galios įvertinimui yra naudojama komercinè kompiuterinè programa MatrixFrame 4.1. Klumpamosios galios reikalavimai programoje MatrixFrame yra tikrinami pagal abu paminètus projektavimo kodus: EN1993 ir NEN6771. Klumpamoji galia matematiniuose modeliuose (3.1)-(3.5) ir (3.6)(3.10) yra ivertinamas naudojant konstruktyvinius apribojimus (3.4) ir (3.9), kurie yra apskaičiuoti pagal projektavimo standartu EN1993 arba NEN6771 (gali būti ir kitų) reikalavimus.

Elementas $k$ tenkina klumpamosios galios reikalavimus jei maksimali vienetiné patikra (unity check) $U C_{k}$ apskaičiuota pagal projektavimo standartu reikalavimus yra mažesnè arba lygi vienetui t. y. $U C_{k} \leq 1 . U C_{k}$ yra elemento skaičiuotinès vertès ir skaičiuotinio atspario santykis. Pavyzdžiui, kai elementas $k$ yra tik gniuždomas pagal EN1993 yra taikoma formulè (3.11), kur santykis $\frac{N_{E d}}{N_{b, R d}}$ igauna vienetinés patikros prasmę t. y. $U C_{k}=\frac{N_{k, E d}}{N_{k, b, R d}} \leq 1$.

- Rèmo projektinis uždavinys yra sprendžiamas pagal matematinị modeli (3.1)(3.5) iteracijomis. Iteracijų blokschema parodyta 3.4 paveiksle. 


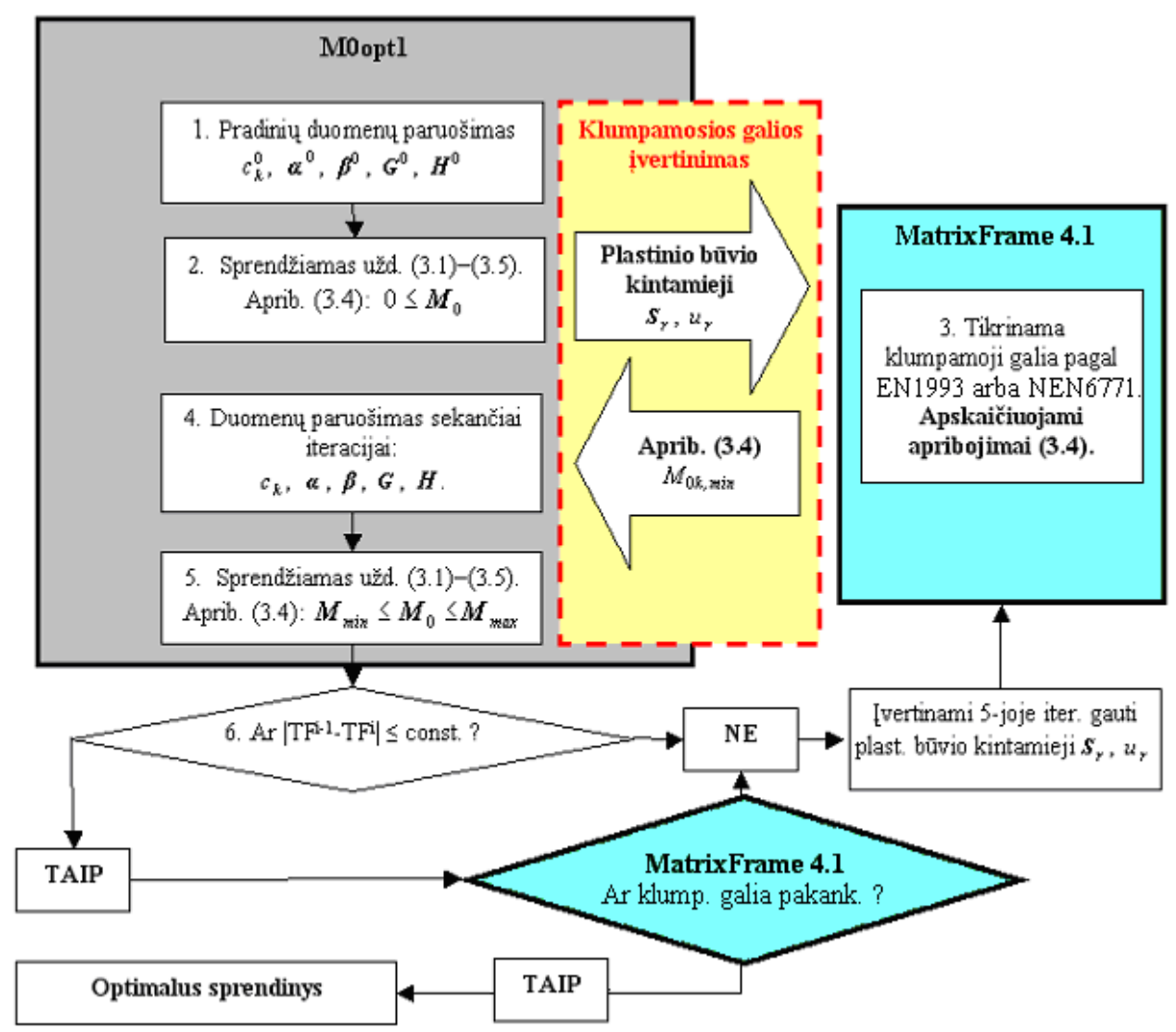

3.4 pav. Klumpamosios galios ịvertinimo projektiniame uždavinyje schema

Fig. 3.4. Flowchart of the proposed solution algorithm for the design problem

Iteracija 1. Infliuentinès matricos $\boldsymbol{\alpha}^{0}, \boldsymbol{\beta}^{0}, \boldsymbol{G}^{0}, \boldsymbol{H}^{0}$ ir takumo sąlygu koeficientai $c_{k}^{0}, k \in K$ yra apskaičiuojami pagal užsiduotus pradinius skerspjūvius $A_{k}^{0}, \quad k \in K$. Uždavinio kintamuju $M_{0 k}$ apribojimai yra $M_{0, k, \min }=0 \leq M_{0, k} \leq M_{0, k, \max }=\infty$ (ribojamas tik kintamujų $M_{0 k}$ ženklas).

Iteracija 2. Sprendžiamas uždavinys (3.1)-(3.5) ir gaunamas naujas ribinių momentų $M_{0 k}^{*}, k \in K$ pasiskirstymas. Naujų skerspjūviai gali būti parenkami dviem būdais: keičiant skerspjūvių dimensijas (tolydus optimizavimas) arba 
parenkant juos iš skerspjūvių sortamento pagal formulę $W_{p l}^{*} \geq M_{0 k}^{*} / \sigma_{y k}$ (diskretinis optimizavimas).

Iteracija 3. Plastinio būvio kintamieji, liekamosios įrąžos $\boldsymbol{S}_{r}$ ir liekamieji poslinkiai $\boldsymbol{u}_{r}$, yra integruojami į MatrixFrame klumpamosios galios skaičiavimus. Jei maksimali klumpamosios galios patikra $U C_{k}>1, k \in K$, tai keičiant skerspjūvių parametrus arba parenkat juos iš sortamento surandami skerspjūviai tenkinantys atspario reikalavimus $U C_{k} \leq 1$. Tokiu būdu randami minimalūs ribiniai $M_{0 k, \min }$. Tai reiškia, kad sekančioje iteracijoje ribiniai momentai $M_{0 k}$ turi būti didesni arba lygūs $M_{0 k, \min }$.

Iteracija 4. Apskaičiuojamos naujos infliuentinès matricos $\boldsymbol{\alpha}, \boldsymbol{\beta}, \boldsymbol{G}, \boldsymbol{H}$, ir koeficientai $c_{k}, k \in K$ pagal antroje iteracijoje apskaičiuotus skerspjūvius $A_{k}$.

Iteracija 5. Sprendžiamas uždavinys (3.1)-(3.5) panaudojant ketvirtoje iteracijoje perskaičiuotas matricas $\boldsymbol{\alpha}, \boldsymbol{\beta}, \boldsymbol{G}, \boldsymbol{H}$ ir koeficientus $c_{k}$ ir trečioje iteracijoje apskaičiuotus ribinių momentų ribines reikšmes $M_{0 k, \min }$.

Iteracija 6. Iteracijos 3-5 yra kartojamos tol kol apskaičiuotieji skerspjūviai $A_{k}$ konverguoja norimu tikslumu.

Visų elementų $k, k \in K$ klumpamosios galios reikalavimai įvertinami iteracijoje 3 surandant tokius skerspjūvius $A_{k}\left(M_{0 k, \min }\right)$, kurie tenkina reikalavimus $U C_{k} \leq 1$.

•• Rèmo apkrovos optimizavimo uždavinys sprendžiamas pagal matematini modeli (3.6)-(3.10) sprendžiant ji iteracijomis. Iteracijų blokschema parodyta 3.5 pav.

Iteracija 1. Sprendžiamas uždavinys (3.6)-(3.10), surandamas naujas apkrovų kitimo ribų pasiskirstymas $\boldsymbol{F}_{\text {sup }}, \boldsymbol{F}_{\text {inf }}$. Uždavinio nežinomujų apribojimai (3.9) $\boldsymbol{F}_{\text {max }}, \boldsymbol{F}_{\text {min }}$ yra $0 \leq \boldsymbol{F}_{\text {sup }} \leq \boldsymbol{F}_{\text {max }}=\infty, \boldsymbol{F}_{\text {min }}=-\infty \leq \boldsymbol{F}_{\text {inf }} \leq 0$ (ribojamas tik nežinomujuc $\boldsymbol{F}_{\text {sup }}$ ir $\boldsymbol{F}_{\text {inf }}$ ženklas). 


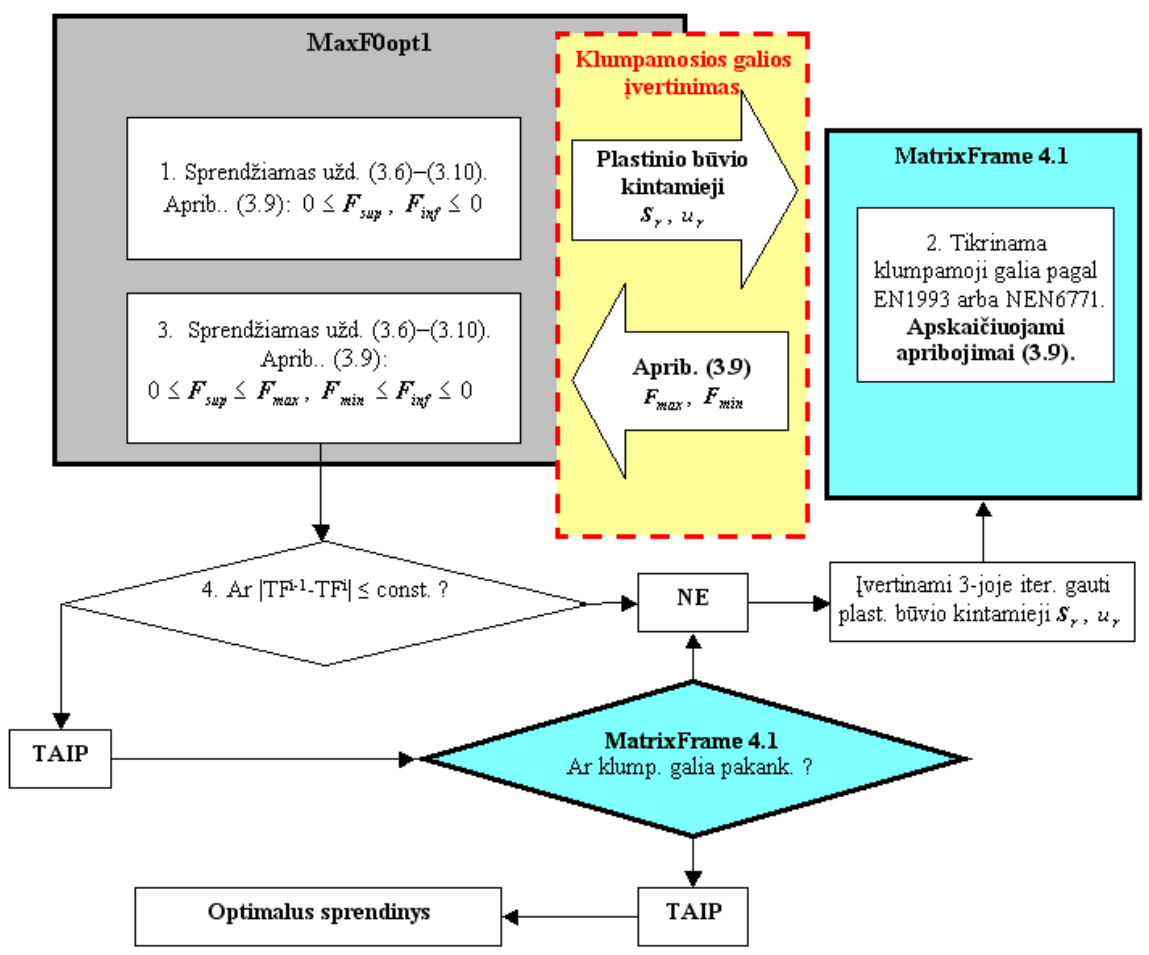

3.5 pav. Klumpamosios galios įvertinimo patikrinamajame uždavinyje schema

Fig. 3.5. Flowchart of the proposed solution algorithm for the checking problem

Iteracija 2. Plastinio būvio kintamieji, liekamosios įrąžos $\boldsymbol{S}_{r}$ ir liekamieji poslinkiai $\boldsymbol{u}_{r}$, yra integruojami i MatrixFrame klumpamosios galios skaičiavimus. Jei maksimali klumpamosios galios patikra $U C_{k}>1, k \in K$, tai keičiant apkrovos sriti $\boldsymbol{F}_{j}$ randama tokia apkrovos sritis, kuri užtikrina $U C_{k} \leq 1$. Šiuo atveju randama apkrovos kitimo ribu apribojimai $\boldsymbol{F}_{\max }$ ir $\boldsymbol{F}_{\text {min }}$. Tai reiškia, kad sekančioje iteracijoje apkrovos kitimo ribos $\boldsymbol{F}_{\text {sup }}$ ir $\boldsymbol{F}_{\text {inf }}$ negali viršyti apkrovos kitimo ribų apribojimų $\boldsymbol{F}_{\max }$ ir $\boldsymbol{F}_{\min }$ užtikrinančių klumpamosios galios reikalavimus.

Iteracija 3. Uždavinys (3.6)-(3.10) sprendžiamas panaudojant antroje iteracijoje apskaičiuotus apkrovų kitimo ribų apribojimus $\boldsymbol{F}_{\max }$ ir $\boldsymbol{F}_{\text {min }}$. 
Iteracija 4. Iteracijos 2 ir 3 yra karojamos tol kol apkrovų kitimo ribos $\boldsymbol{F}_{\text {sup }}$ ir $\boldsymbol{F}_{\text {inf }}$ sutampa su prieš tai gautomis apkrovų kitimo ribomis norimu tikslumu.

Visų elementų $k, k \in K$ klumpamosios galios reikalavimai įvertinami iteracijoje 2 surandant tokius apkrovų kitimo ribų apribojimus $\boldsymbol{F}_{\max }$ ir $\boldsymbol{F}_{\min }$, kurie tenkina reikalavimus $U C_{k} \leq 1$.

\subsubsection{Optimizavimo programu ir MatrixFrame integruotas panaudojimas}

Projektiniam optimizavimo uždaviniui spręsti naudojama M0opt1 programa, o patikrinamajam - MaxFopt1. Klumpamosios galios tikrinimui pasitelkiama komercine programa MatrixFrame 4.1 su idiegtais projektavimo standartais EN1993 ir NEN6771. Principiniai optimizavimo uždavinių sprendimo žingsniai, bei duomenų mainai parodyti 3.4 ir 3.5 paveiksluose. Šiame poskyryje bus detaliau apžvelgta plastinio būvio kintamujų $\boldsymbol{S}_{r}$ ir $\boldsymbol{u}_{r}$ integracijos metodas i MatrixFrame programą.

MatrixFrame programoje apkrovu deriniai (P.C. - persisten combination) yra sudaromi iš apkrovimu ( $\mathrm{LC}$ - load case), kur pastarieji sudaryti iš elementarių apkrovų (LD - load definition). Apkrovos gali būti koncentruotos, tolygiai išskirstytos, nuosavo svorio, temperatūrinès ir t. t.

Tarkime, rèmas yra veikiamas dviejų kintamų apkrovų: vejjo $\boldsymbol{F}_{1}$ ir sniego $\boldsymbol{F}_{2}$, bei pastovios apkrovos $\boldsymbol{F}_{c}$. Kai veikia dvi kintamos apkrovos, KKA viršūnių skaičius $p=2^{2}=4$ t. y. rèmas yra veikiamas keturių apkrovos derinių (P.C.1 $\div$ P.C.4 parodyti 3.6 pav. a). Vejjo ir sniego apkrovos kinta tarp ribų: $\boldsymbol{F}_{1, \text { inf }}[=\mathrm{LC} 1] \leq \boldsymbol{F}_{1} \leq \boldsymbol{F}_{1, \text { sup }}[=\mathrm{LC} 2], \quad \boldsymbol{F}_{2, \text { inf }}[=\mathrm{LC} 4=0] \leq \boldsymbol{F}_{2} \leq \boldsymbol{F}_{2, \text { sup }}[=\mathrm{LC} 3] . \quad$ Apkrovimai (LC) parodyti 3.6 b) paveiksle. Jame matome šešis apkrovimus, kur LC5 atitinka pastovią apkrovą $\boldsymbol{F}_{c}[=\mathrm{LC} 5]$. Šeštasis apkrovimas LC6 (pav. 3.6 c) yra nulinis t. y. savyje jis turi vieną nuliui prilyginta apkrovą LD29. Šis apkrovimas sukurtas, kad atliktų duomenų konteinerio vaidmeni t. y. apkrovimą LC6 atitinkantys rezultatai yra užpildomi plastinio būvio kintamaisiais $\boldsymbol{S}_{r}$ ir $\boldsymbol{u}_{r}$ gautais iš optimizavimo programų, kurios savo ruožtu juos apskaičiuoja nuo apkrovų derinių P.C. $1 \div$ P.C.4. KKA viršūnès atitinka apkrovų derinius:

$$
\begin{aligned}
& k_{11} \boldsymbol{F}_{1, \text { sup }}+k_{12} \boldsymbol{F}_{2, \text { sup }}+k_{13} \boldsymbol{F}_{c} \Rightarrow \text { P.C. } 1=k_{11} \mathrm{LC} 1+k_{12} \mathrm{LC} 3+k_{13} \mathrm{LC} 5+1.0 * \text { LC6, } \\
& k_{21} \boldsymbol{F}_{1, \text { sup }}+k_{22} \boldsymbol{F}_{2, \text { inf }}+k_{23} \boldsymbol{F}_{c} \Rightarrow \text { P.C. } 2=k_{21} \mathrm{LC} 1+k_{22} \mathrm{LC} 4+k_{23} \mathrm{LC} 5+1.0 * \text { LC6, }
\end{aligned}
$$


$k_{31} \boldsymbol{F}_{1, \text { inf }}+k_{32} \boldsymbol{F}_{2, \text { sup }}+k_{33} \boldsymbol{F}_{c} \Rightarrow$ P.C.3 $=k_{31} \mathrm{LC} 2+k_{32}$ LC3 $+k_{33}$ LC5 + 1.0*LC6, $k_{41} \boldsymbol{F}_{1, \text { inf }}+k_{42} \boldsymbol{F}_{2, \text { inf }}+k_{43} \boldsymbol{F}_{c} \Rightarrow$ P.C.4 $=k_{41} \mathrm{LC} 2+k_{42} \mathrm{LC} 4+k_{43} \mathrm{LC} 5+1.0 *$ LC6.

a)

\begin{tabular}{|c|c|c|c|c|c|c|}
\hline \multicolumn{7}{|c|}{ 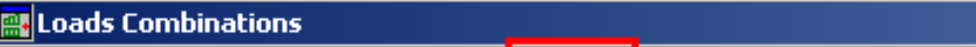 } \\
\hline & Label & Description & P.C.1 & P.C. 2 & P.C.3 & P.C. 4 \\
\hline & LC1 & Vejas Fsup & 1.00 & 1.00 & & \\
\hline$\nabla$ & LC2 & Vejas Finf & & & 1.00 & 1.00 \\
\hline & LC3 & Sniegas Fsup & 1.00 & & 1.00 & \\
\hline & LC4 & Sniegas Finf & & 1.00 & & 1.00 \\
\hline & LC5 & Naudinga [pastovi] & 1.00 & 1.00 & 1.00 & 1.00 \\
\hline & LC6 & Sr & 1.00 & 1.00 & 1.00 & 1.00 \\
\hline
\end{tabular}

b)

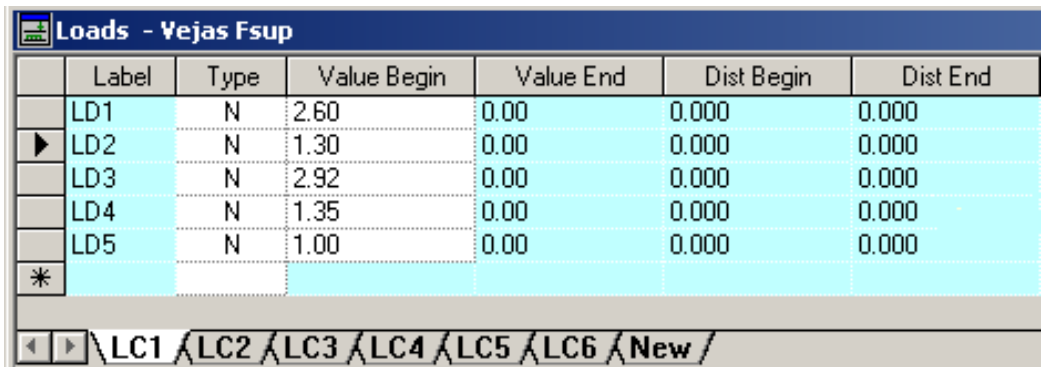

c)

\begin{tabular}{||c|c|c|c|c|c|c|}
\hline \multicolumn{2}{|c|}{} & Loads - Sr \\
\hline \hline & Label & Type & Value Begin & Value End & Dist Begin & Dist End \\
\hline LD29 & N & 0.00 & 0.000 & 0.000 \\
\hline & & & & \\
\hline
\end{tabular}

3.6 pav. Apkrovų kombinacijų sudarymo principas MatrixFrame programoje

Fig. 3.6. The principle of load combination creation in MatrixFrame software 


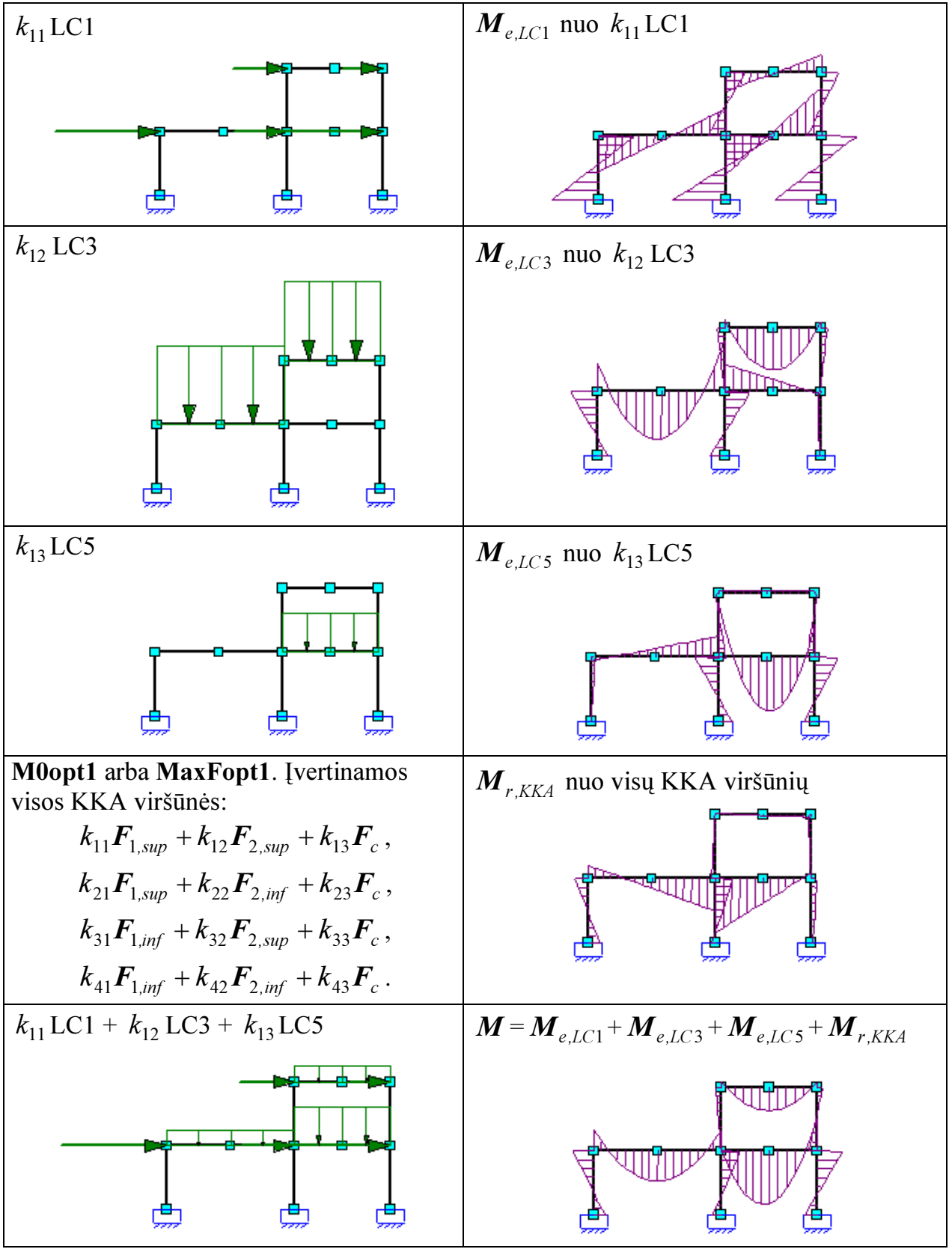

3.7 pav. Liekamujų i̇rąžų $\boldsymbol{S}_{r}$ integravimas į apkrovos derinị P.C.1

Fig. 3.7. Incorporatin of residual forces $\boldsymbol{S}_{r}$ into load combination P.C.1 
Paveiksle 3.7 parodyta kaip yra sumuojami liekamieji momentai $\boldsymbol{M}_{r}$ apkrovos derinyje. Tokiu pat principu yra sumuojamos ir kitos liekamosios irąžos $\boldsymbol{N}_{r}, \boldsymbol{V}_{r}$ bei liekamieji poslinkiai $\boldsymbol{u}_{r}$.

Apskaičiavus sumines įrąžas atliekamas konstrukcijos stiprumo klumpamosios galios patikra pagal projektavimo standartus t. y. tikrinama ar $U C_{k} \leq 1$ (3.8 pav.)

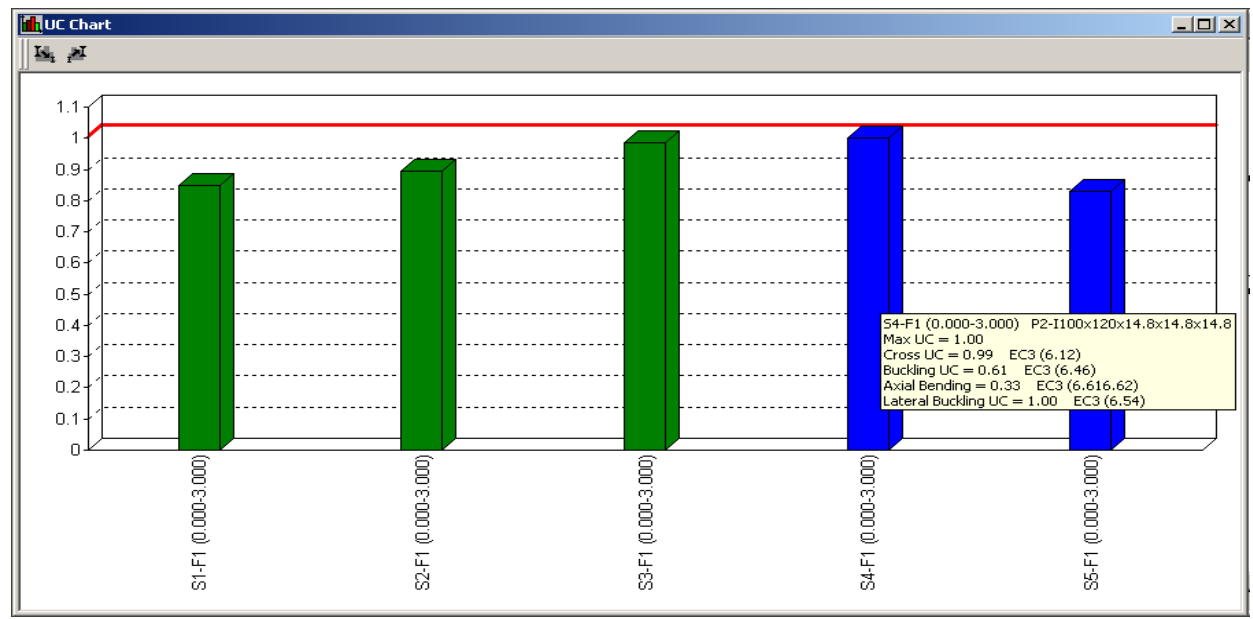

3.8 pav. Vienetines patikros UC grafas konstrukcijos elementams

Fig. 3.8. Unity check graph for elements of structure

Jei $U C_{k}>1$ nors vienam elementui $k$, tai priklausomai nuo sprendžiamo uždavinio tipo yra keičiami skerspjūvio parametrai (3.9 pav., projektinis uždavinys), arba keičiamos apkrovos ribos (3.10 pav., patikrinamasis uždavinys) tol kol pasiekiama $U C_{k} \leq 1$ visiems elementams $k$. Projektinio uždavinio atveju, kai $U C_{k} \leq 1$ yra apskaičiuojami konstrukciniai apribojimai $\boldsymbol{S}_{\min }$ ir $\boldsymbol{S}_{\max }$.

\begin{tabular}{|c|c|c|c|c|c|c|c|c|c|}
\hline \multicolumn{8}{|c|}{ 国 Sections } & \multicolumn{2}{|c|}{ - } \\
\hline & Shape & Tapered & $h B$ & $h E$ & $t_{f}$ & $t_{w}$ & $t_{f 2}$ & $\mathrm{bB}$ & $\mathrm{bE}$ \\
\hline \multirow[t]{3}{*}{$\nabla$} & I-Shape & $\Gamma$ & 0.150 & 0.150 & 0.0220 & 0.0220 & 0.0220 & 0.150 & 0.00 \\
\hline & I-Shape & 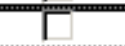 & 0.120 & 0.120 & 0.0148 & 0.0148 & 0.0148 & 0.100 & 0.00 \\
\hline & I-Shape & F & 0.200 & 0.200 & 0.0302 & 0.0302 & 0.0302 & 0.150 & 0.00 \\
\hline
\end{tabular}

3.9 pav. Skerspjūvio parametrų keitimo lentelè MatrixFrame

Fig. 3.9. Cross-sectional parameters definition grid in MatrixFrame 
Patikrinamojo uždavinio atveju apkrovos apkrovimuose užduodamos parametrizuotai (3.10 pav., a), o parametrai suskaičiuojami atskiroje lentelèje (3.10 pav., b). Tokiu būdu galima „išpūsti“ arba „sutraukti“ KKA kitimo sriti (3.1 pav.) pakeičiant vieno (galima ir keliu) parametrų reikšmes, tol kol bus gauta $U C_{k} \leq 1$ visiems elementams t. y. bus apskaičiuoti apribojimai $\boldsymbol{F}_{\max }$ ir $\boldsymbol{F}_{\min }$.

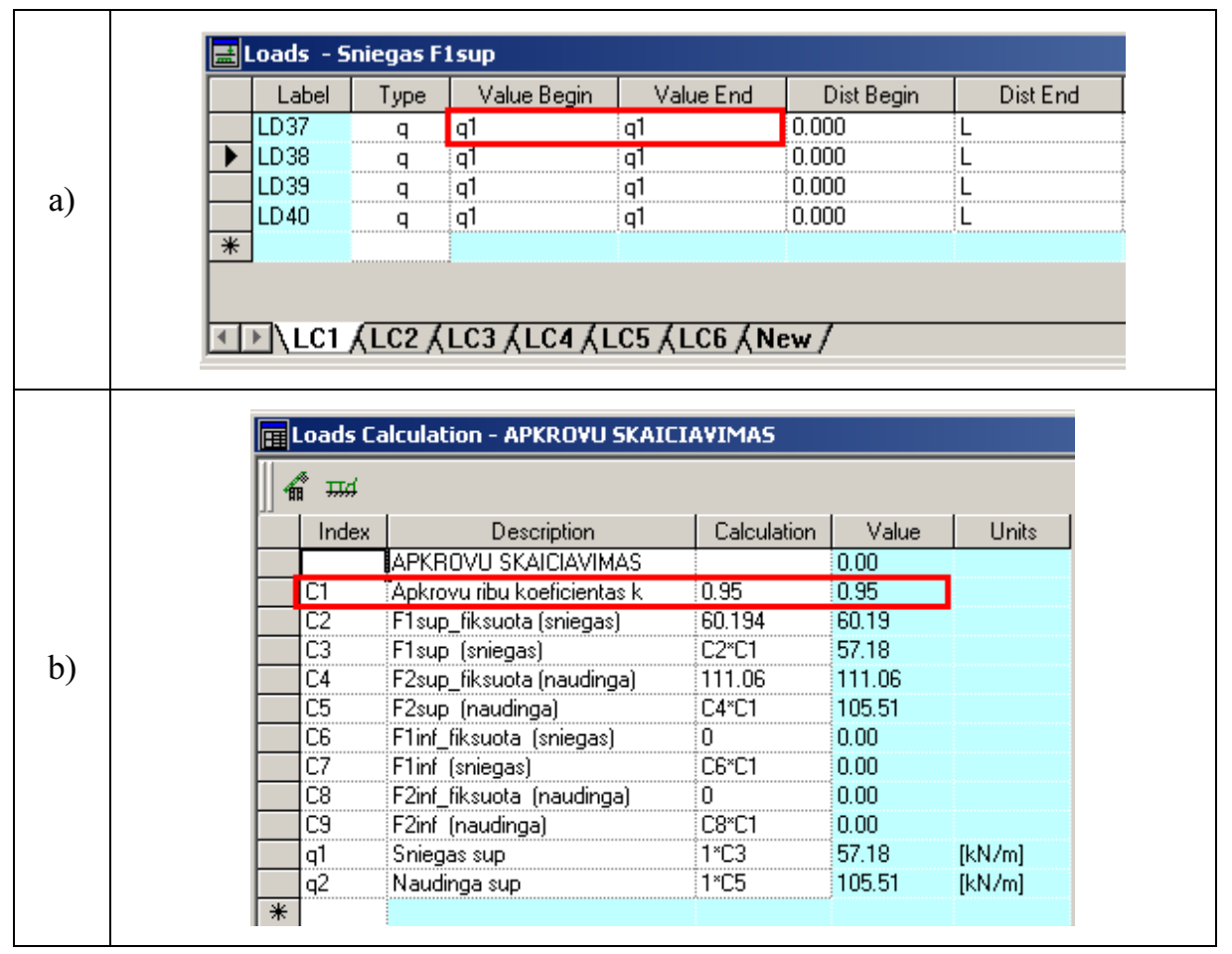

3.10 pav. Parametrizuotos apkrova MatrixFrame

Fig. 3.10. Parametric loading in MatrixFrame

Plastinio būvio kintamujų manai tarp programų realizuojami per tekstini faila. Be abejo, yra galimybè mainus realizuoti per dinamiškai prijungiamą biblioteką (dll). Tobulintinas realizuotos sąsajos dalykas yra tai, kad tamprios irąžoos yra skaičiuojamos tiek optimizavimo programose, tiek MatrixFrame lygiagrečiai, t. y. du kartus, kas nèra labai efektyvu. Tai sąlygota skirtingų baigtinių elementu naudojimo optimizavimo programose ir MatrixFrame. Pastarojoje programoje visi skaičiavimai realizuoti poslinkiniais baigtiniais elementais, o optimizavimo programose pusiausvyraisiais baigtiniais elementais. Tačiau autorius šioje disertacijoje siekẻ pademonstruoti programų integracijos galimybę, bei būda, kaip i̇manoma projektuoti prisitaikiusią konstrukciją standartų kontekste. Šis tikslas, autoriaus nuomone, buvo pasiektas. 
Šiame poskyryje išnagrinètas integracijos metodas svarbus ne tiek informacinių technologijų atžvilgiu, o tuo, kad igalina ivvertinti plastini konstrukcijos darba, kuris sąlygojamas apkrovos derinių (o ne vienos apkrovimo istorijos nagrinejjimo!), kurie aktualūs konstrukcijų projektavimui pagal standartų reikalavimus. Kaip žinoma, egzistuoja daug pramoninių kompiuterinių programų, puikiai gebančių ivvertinti plastini konstrukcijos darba, bet tik nuo vieno apkrovimo. Be abejo, yra įmanoma analizuoti konstrukcijos plastinį darbą nuo keleto apkrovos derinių, skaičiuojant kiekvieno derinio poveikị ir galiausiai sudarant rezultatų gaubtinę. Tačiau ši gaubtinè nèra tapati tikram plastiniam konstrukcijos darbui, nes nuo vieno apkrovimo susidariusios plastinès deformacijos įtakoja kitu apkrovimų sąlygotą plastinę konstrukcijos elgseną.

\subsubsection{Rèmo projektinio uždavinio pavyzdys}

Pasiūlyta skaičiavimo technika yra iliustruojama dviejų aukštų rẻmo (3.11 pav.) patikrinamojo uždavinio (3.1)-(3.5) sprendimu. Uždaviniui (3.1)(3.5) spręsti naudota autoriaus sukurta kompiuterinè programa M0opt1, kurios pagrindas yra Rozeno projektuojamujų gradientų metodas (Bazaraa et al. 2004). Klumpamosios galios ivertinimui naudojama kompiuterine projektavimo programa MatrixFrame 4.1. Klumpamoji galia ivertinama pagal projektavimo standartą EN1993 (formulès (3.11)-(3.14)).

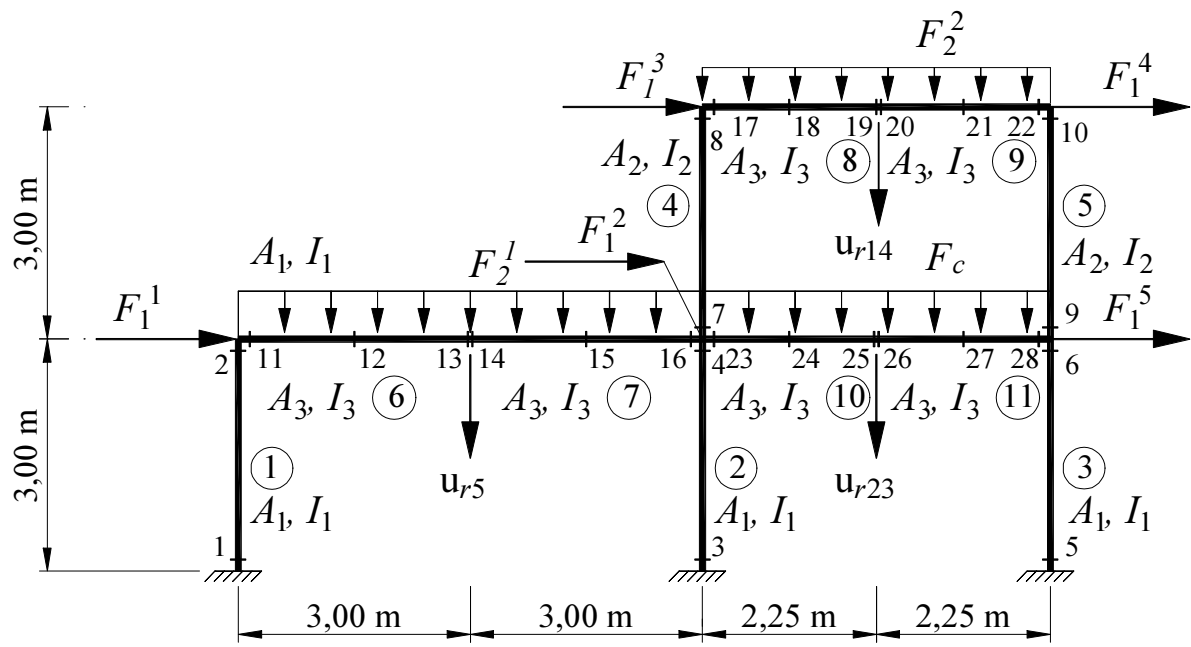

3.11 pav. Rèmo diskretizacija

Fig. 3.11. Discretized frame 
Rėmas yra apkrautas dviem nepriklausomomis apkrovomis: horizontaliomis koncentruotomis apkrovomis $\boldsymbol{F}_{1}=\left[F_{1}^{1}, F_{1}^{2}, F_{1}^{3}, F_{1}^{4}, F_{1}^{5}\right]$ veikiančiomis rèmo mazguose ir vertikaliomis vienodai paskirstytomis $\boldsymbol{F}_{2}=\left[F_{2}^{1}, F_{2}^{2}\right]$ veikiančiomis stogo sijas 6, 7, 8 ir 9 (3.11 pav.). Pastovi apkrova $\boldsymbol{F}_{c}$ veikia grindu sijas 10 ir 11 . Apkrovuc kitimo ribos užrašomos nelygybėmis $\boldsymbol{F}_{1, \text { inf }} \leq \boldsymbol{F}_{1} \leq \boldsymbol{F}_{1, \text { sup }}$, $\boldsymbol{F}_{2, \text { inf }} \leq \boldsymbol{F}_{2} \leq \boldsymbol{F}_{2, \text { sup }}, \quad$ kur $\quad \boldsymbol{F}_{1, \text { inf }}=\{-9,75,-4,9,-5,-6,75,-19,5\} \mathrm{kN}$, $\boldsymbol{F}_{1, \text { sup }}=\{13,6,5,6,75,5,14,6\} \mathrm{kN}, \quad \boldsymbol{F}_{2, \text { inf }}=\{0,0\}, \quad \boldsymbol{F}_{2, \text { sup }}=\{48,48\} \mathrm{kN} / \mathrm{m} \quad$ ir $\boldsymbol{F}_{c}=117 \cdot \mathrm{kN} / \mathrm{m}$.

Rėmas pagamintas iš plieno, kurio tamprumo modulis $E=210 \mathrm{GPa}$ ir takumo riba $\sigma_{y}=235 \mathrm{MPa}$. Rèmo kolonų, stogo ir grindų sijų skerspjūviai parodyti 3.12 pav.
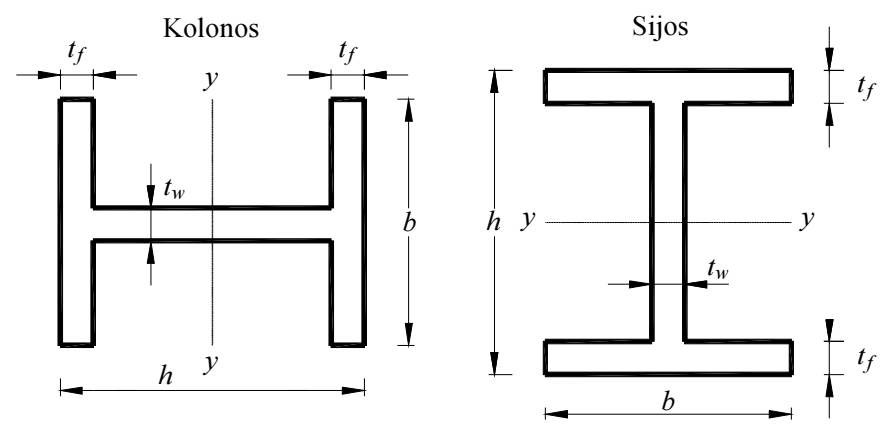

3.12 pav. Rèmo kolonų ir sijų skerspjūviai

Fig. 3.12. Cross-sectional shapes for frame columns and beams

Skerspjūvių parametrai $b$ ir $h$ tolydaus optimizavimo metu nekinta, keičiamas tik lentynos ir sienutès storis $t=t_{f}=t_{w}$. Skerspjūvio dydžiai $b$ ir $h$ parodyti 3.3 lenteleje. Diskretinio optimizavimo metu skerspjūviai parenkami iš skerspjūvių gamintojų pateiktų sortamentų.

Ribinès skerspjūvio įražos kai $t=t_{f}=t_{w}$ apskaičiuojamos pagal formules

$$
\begin{gathered}
M_{0}=\sigma_{y} W_{p l, y}=\sigma_{y}\left(t^{3}-(b+h) t^{2}+\left(\frac{h^{2}}{4}+b h\right) t\right), \\
N_{0}=\sigma_{y} A=\sigma_{y}(2 b t+t(h-2 t)) .
\end{gathered}
$$


3.3 lentelè. Skerspjūvių parametrų reikšmès

Table 3.3. Values of cross-sections

\begin{tabular}{|c|c|c|}
\hline Elementai $k, k \in K$ & $\begin{array}{c}b, \\
\mathrm{~m}\end{array}$ & $\begin{array}{c}h, \\
\mathrm{~m}\end{array}$ \\
\hline $1,2,3$ & 0,15 & 0,15 \\
\hline 4,5 & 0,1 & 0,12 \\
\hline $6,7,8,9,10,11$ & 0,15 & 0,2 \\
\hline
\end{tabular}

Pagrindinè užduotis yra nustatyti prisitaikiusio rèmo minimalų tūri (3.11 pav.) kai diskretizuoto rèmo vidinių jègu vektorius $\boldsymbol{S}=(\boldsymbol{M}, \boldsymbol{N})^{T}=$ $\left(M_{1}, M_{2}, M_{3}, \ldots, M_{28}, N_{1}, N_{2}, \ldots, N_{11}\right)^{T}=\left(S_{i}\right)^{T}, \quad i=1,2, \ldots, n=39$, kuriame yra ivertinti ir lenkimo momentai $M$, ir ašinès jègos $N$. Šiuo atveju rèmo projektinis uždavinys sprendžiamas pagal matematini modelị (3.1)-(3.5). Nežinomieji yra kolonų ir sijų skerspjūvio plotai $A_{k}, k \in K$ ir plastinių daugiklių vektoriai $\lambda_{j}, j=1,2, \ldots, 4$. Buvo nagrinèti penki skaičiavimo variantai:

Atvejis C1. Ivertintos tik stiprumo sąlygos (3.2). Tolydus optimizavimas;

Atvejis C2. Ivertintos tik stiprumo (3.2) ir standumo sąlygos (3.5). Užsiduoti poslinkiu apribojimai: $-\infty \leq u_{5} \leq 0,03 \mathrm{~m},-\infty \leq u_{14} \leq 0,0225 \mathrm{~m}$, $-\infty \leq u_{23} \leq 0,0225 \mathrm{~m}$ (3.2 pav.). Tolydus optimizavimas;

Atvejis C3. Ivertintos tik stiprumo (3.2) ir klumpamosios galios (konstruktyvinių apribojimų) (3.4) sąlygos. Tolydus optimizavimas;

Atvejis C4. Ivertintos tik stiprumo (3.2) ir klumpamosios galios (3.4) sąlygos. Diskretinis optimizavimas;

Atvejis C5. Ivertintos visos (stiprumo (3.2), standumo (3.5) ir klumpamosios galios (3.4.) sąlygos). Užsiduoti poslinkių apribojimai: $-\infty \leq u_{5} \leq 0,03 \mathrm{~m},-\infty \leq u_{14} \leq 0,0225 \mathrm{~m},-\infty \leq u_{23} \leq 0,0225 \mathrm{~m}$ (3.2 pav.). Tolydus optimizavimas.

Skaičiavimai C1 ir C2 atvejams buvo atlikti su programa M0opt1, o atvejai C3-C5 skaičiuoti integruotai panaudojant M0opt1 ir MatrixFrame programas, pagal iteracijas aprašytas 3.4 .4 poskyryje ir 3.4 paveiksle. Visu paminètu skaičiavimo atvejų rezultatai, priklausomai nuo pritaikytu apribojimų parodyti 3.4 lentelèje. 
3.4 lentelè. Projektinio uždavinio skaičiavimo rezultatai

Table 3.4. Calculated results for the design problem

\begin{tabular}{|r|c|c|c|c|c|c|}
\hline Atvejis & $\begin{array}{c}M_{01}, \\
\mathrm{Nm}\end{array}$ & $\begin{array}{c}M_{02}, \\
\mathrm{Nm}\end{array}$ & $\begin{array}{c}M_{03}, \\
\mathrm{Nm}\end{array}$ & $\begin{array}{c}\text { Tikslo } \\
\text { funkcija } \\
(\mathrm{TF})\end{array}$ & $\begin{array}{c}\text { Tūris, } \\
\mathrm{m}^{3}\end{array}$ & $\begin{array}{c}\text { Plastiniu } \\
\text { deformaciju } \\
\text { vieta }\end{array}$ \\
\hline $\mathrm{C} 1$ & 75441 & 41673 & 204168 & 3991522 & 0,26149777 & $6,2,23$ \\
\hline $\mathrm{C} 2$ & 93970 & 34942 & 223206 & 4403462 & 0,292369813 & 23 \\
\hline $\mathrm{C} 3$ & 120537 & 48302 & 186579 & 4173339 & 0,283231289 & 23 \\
\hline $\mathrm{C} 4$ & 174986 & 57610 & 189018 & 4755802 & 0,350856685 & 23 \\
\hline
\end{tabular}

Skaičiavimo atvejais $\mathrm{C} 2$ ir $\mathrm{C} 5$ suminis poslinkis $u_{23}$ pasiekè viršutinę poslinkio apribojimo ribą $u_{\max }=0,0225 \mathrm{~m}$. Diskretinio optimizavimo atveju C4 ribinius momentus $M_{01}=174986 \mathrm{Nm}, M_{02}=57610 \mathrm{Nm}$ ir $M_{03}=189018 \mathrm{Nm}$ atitinka skerspjūviai iš sortamento HE240, HE160 ir IPE330. Pažymètina, jog tokie pat diskretiniai skerspjūviai buvo gauti ketvirtojoje ir penktojoje iteracijose, todèl optimizavimo procesas buvo sustabdytas ir priimta, jog gautas optimalus sprendinys. Diskretinis optimizavimas yra labai svarbus statybinių konstrukcijų projektavime, tačiau ir tolydinis optimizavimas (atvejai C1-C3, C5) gali būti ivadinis žingsnis i diskretini optimizavimą. Pavyzdžiui, naudojant skerspjūvių, gautų tolydinio optimizavimo metu, charakteristikas galima parinkti artimiausią pagal charakteristikas diskretinị skerspjūvį. Pagrindinio optimizavimo uždavinio optimalaus sprendinio kriterijus yra tikslo funkcijos konvergavimas norimu tikslumu. Optimizavimo uždavinio tikslo funkcijos konvergavimas visiems atvejams parodytas 3.13. pav.
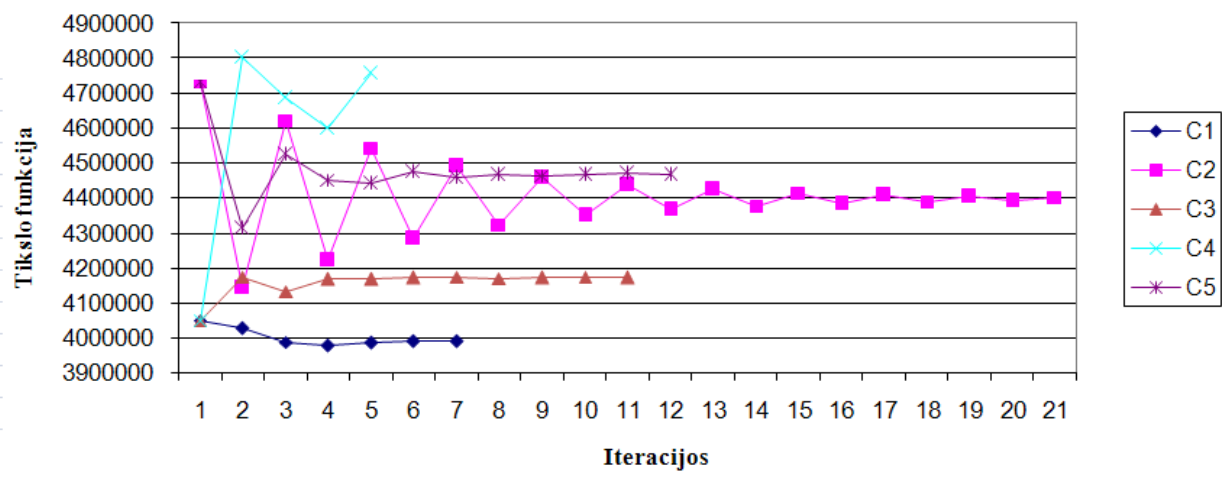

3.13 pav. Optimizavimo uždavinio tikslo funkcijos konvergavimas

Fig. 3.13. Convergence of the optimization-problem objective function 
C2 atveju konvergavimo dydis yra lygus $\delta=0,25 \%$, iteratyvinis procesas parodytas 3.5 lenteleje.

3.5 lentelè. Optimizavimo uždavinio tikslo funkcijos konvergavimas $\mathrm{C} 2$ atveju

Table 3.5. Convergence of the optimization-problem objective function for case $\mathrm{C} 2$

\begin{tabular}{|c|c|c|c|c|c|}
\hline Iteracija & $\begin{array}{c}M_{01}, \\
\mathrm{Nm}\end{array}$ & $\begin{array}{c}M_{02}, \\
\mathrm{Nm}\end{array}$ & $\begin{array}{c}M_{03}, \\
\mathrm{Nm}\end{array}$ & $\mathrm{TF}$ & $\delta$ TF \% \\
\hline 1 & 96888 & 42400 & 240460 & 4733292 & \\
\hline 2 & 93807 & 37591 & 204883 & 4143051 & 12,47 \\
\hline 3 & 95221 & 37257 & 236064 & 4621487 & $-11,55$ \\
\hline 4 & 93755 & 35439 & 211158 & 4223807 & 8,61 \\
\hline 5 & 94299 & 35814 & 231966 & 4543060 & $-7,56$ \\
\hline 6 & 93670 & 34931 & 215459 & 4284503 & 5,69 \\
\hline 7 & 94140 & 35320 & 228876 & 4492323 & $-4,85$ \\
\hline 8 & 93767 & 34832 & 218090 & 4324254 & 3,74 \\
\hline 9 & 94083 & 35129 & 226802 & 4459547 & $-3,13$ \\
\hline 10 & 93840 & 34837 & 219776 & 4350228 & 2,45 \\
\hline 11 & 94044 & 35043 & 225444 & 4438312 & $-2,02$ \\
\hline 12 & 93885 & 34860 & 220870 & 4367176 & 1,60 \\
\hline 13 & 94016 & 34999 & 224559 & 4424527 & $-1,31$ \\
\hline 14 & 93912 & 34882 & 221583 & 4378244 & 1,05 \\
\hline 15 & 93997 & 34973 & 223983 & 4415558 & $-0,85$ \\
\hline 16 & 93929 & 34898 & 222047 & 4385447 & 0,68 \\
\hline 17 & 93984 & 34958 & 223609 & 4409735 & $-0,55$ \\
\hline 18 & 93939 & 34909 & 222348 & 4390121 & 0,44 \\
\hline 19 & 93975 & 34948 & 223365 & 4405942 & $-0,36$ \\
\hline 20 & 93946 & 34916 & 222545 & 4393195 & 0,29 \\
\hline 21 & 93970 & 34942 & 223206 & 4403462 & $-0,23$ \\
\hline & & & & & \\
\hline
\end{tabular}

\subsubsection{Rẻmo apkrovos optimizavimo uždavinio pavyzdys}

Pasiūlyta skaičiavimo technika yra iliustruojama dviejų aukštų rẻmo (3.11 pav.) projektinio uždavinio (3.6)(3.10) sprendimu. Uždaviniui (3.6)(3.10) spręsti naudota autoriaus sukurta kompiuterine programa MaxFopt1, kurios pagrindas yra Rozeno projektuojamuju gradientų metodas (Bazaraa et al. 2004). Klumpamosios galios ìvertinimui naudojama kompiuterinè projektavimo programa MatrixFrame 4.1. Klumpamoji galia ịvertinama pagal projektavimo standartą 
NEN6771. Rèmas pagamintas iš plieno, kurio tamprumo modulis $E=210 \mathrm{GPa}$ ir takumo riba $\sigma_{y}=235 \mathrm{MPa}$. Rèmo kolonu̧, stogo ir grindų sijų skerspjūviai parodyti 3.6 lenteleje. Skerspjūvių dimensijos lieka nepakitę viso optimizavimo proceso metu.

3.6 lentelè. Skerspjūvių dimensijos

Table 3.6. Values of cross-sections

\begin{tabular}{|c|c|c|c|c|c|c|}
\hline $\begin{array}{c}\text { Elementai } \\
k, k \in K\end{array}$ & $\begin{array}{c}b, \\
\mathrm{~m}\end{array}$ & $\begin{array}{c}h, \\
\mathrm{~m}\end{array}$ & $\begin{array}{c}t, \\
\mathrm{~m}\end{array}$ & $\begin{array}{c}A_{k}, \\
\mathrm{~m}^{2}\end{array}$ & $\begin{array}{c}M_{0 k}, \\
\mathrm{Nm}\end{array}$ & $\begin{array}{c}N_{0 k}, \\
\mathrm{~N}\end{array}$ \\
\hline $1,2,3$ & 0,15 & 0,15 & 0,016 & 0,006688 & 88665 & 1571680 \\
\hline 4,5 & 0,1 & 0,12 & 0,01 & 0,003000 & 31725 & 705000 \\
\hline $\begin{array}{c}6,7,8,9, \\
10,11\end{array}$ & 0,15 & 0,2 & 0,03 & 0,013200 & 21432 & 3102000 \\
\hline
\end{tabular}

Rėmas apkrautas dvejomis nepriklausomomis apkrovomis: horizontaliomis koncentruotomis jègomis $\boldsymbol{F}_{1}=\left\{F_{1}^{1}, F_{1}^{2}, F_{1}^{3}, F_{1}^{4}, F_{1}^{5}\right\}$ veikiančiomis rèmo mazguose ir vertikaliomis vienodai paskirstytomis jègomis $\boldsymbol{F}_{2}=\left\{F_{2}^{1}, F_{2}^{2}\right\}$ veikiančiomis stogo sijas $(6,7,8,9)$. Pastovi apkrova $\boldsymbol{F}_{c}=117 \mathrm{kN} / \mathrm{m}$ veikia grindu sijas $(10,11)$. Apkrovos kitimo ribos yra užrašytos nelygybėmis $\boldsymbol{F}_{1, \text { inf }} \leq \boldsymbol{F}_{1} \leq \boldsymbol{F}_{1, \text { sup }}, \boldsymbol{F}_{2, \text { inf }} \leq \boldsymbol{F}_{2} \leq \boldsymbol{F}_{2, \text { sup }}$, jos yra optimizavimo uždavinio nežinomieji. Pagrindinis tikslas yra prisitaikiusio rèmo (3.11 pav.) apkrovų kitimo ribų radimas kai vidinių diskretizuoto rèmo jègu vektorius yra $\boldsymbol{S}=(\boldsymbol{M}, \boldsymbol{N})^{T}=$ $\left(M_{1}, M_{2}, M_{3}, \ldots, M_{28}, N_{1}, N_{2}, \ldots, N_{11}\right)^{T}=\left(S_{i}\right)^{T}, \quad i=1,2, \ldots, n=39$, kuriame yra ivertinti lenkimo momentai $M$ ir ašinès jègos $N$. Šiuo atveju rèmo projektinis uždavinys sprendžiamas pagal matematini modelị (3.6)-(3.10). Nežinomieji yra apkrovos kitimo ribos $\boldsymbol{F}_{1, \text { inf }}, \boldsymbol{F}_{2, \text { nnf }}, \boldsymbol{F}_{1, \text { sup }}$ ir $\boldsymbol{F}_{2, \text { sup }}$, bei ir plastinių daugikliu vektoriai $\lambda_{j}, j=1,2, \ldots, 4$. Uždavinys (3.6)-(3.10) spręstas pagal iteracijas aprašytas 3.4.4 poskyryje, buvo nagrinèti trys skaičiavimo atvejai:

Atvejis C1. Ivertintos tik stiprumo sąlygos (3.7);

Atvejis C2. Ivertintos tik stiprumo (3.7) ir standumo sąlygos (3.10). Užsiduoti poslinkių apribojimai: $-\infty \leq u_{5} \leq 0,03 \mathrm{~m}$, $-\infty \leq u_{14} \leq 0,0225 \mathrm{~m},-\infty \leq u_{23} \leq 0,0225 \mathrm{~m}$ (3.11 pav.); 
Atvejis C3. Ivertintos tik stiprumo (3.7) ir klumpamosios galios (konstruktyvinių apribojimų) (3.9) sąlygos;

Skaičiavimai $\mathrm{C} 1$ ir $\mathrm{C} 2$ atvejams buvo atlikti su programa MaxFopt1, o atvejis C3 skaičiuotas integruotai panaudojant MaxFopt1 ir MatrixFrame programas, pagal iteracijas aprašytas 3.4 .4 poskyryje ir 3.5 paveiksle. Visu paminètu skaičiavimo atvejų rezultatai, priklausomai nuo pritaikytų apribojimų, parodyti 3.7 lentelèje.

3.7 lentelè. Apkrovos optimizavimo uždavinio skaičiavimo rezultatai

Table 3.7. Calculated results for the load-optimization problem

\begin{tabular}{|c|c|c|c|c|c|c|}
\hline Atvejis & $\begin{array}{c}\boldsymbol{F}_{1, \text { sup }}, \\
\mathrm{N}\end{array}$ & $\begin{array}{c}\boldsymbol{F}_{2, \text { sup }}, \\
\mathrm{N} / \mathrm{m}\end{array}$ & $\begin{array}{c}\boldsymbol{F}_{1, \text { inf }}, \\
\mathrm{N}\end{array}$ & $\begin{array}{c}\boldsymbol{F}_{2, \text { inf }}, \\
\mathrm{N} / \mathrm{m}\end{array}$ & $\mathrm{TF}$ & $\begin{array}{c}\text { Plastiniu } \\
\text { deformaciju } \\
\text { vieta }\end{array}$ \\
\hline $\mathrm{C} 1$ & 23679 & 44035 & -29349 & -10 & 97073 & $4,6,8,23$ \\
\hline $\mathrm{C} 2$ & 15777 & 26006 & -23958 & -10 & 65751 & 4,6 \\
\hline $\mathrm{C} 3$ & 11839 & 19200 & -14673 & -10 & 45722 & 4 \\
\hline
\end{tabular}

Skaičiavimo atveju C2 suminis poslinkis $u_{23}$ pasiekè viršutinę poslinkio apribojimo ribą $u_{\max }=0,0225 \mathrm{~m}$. Iteratyvinis skaičiavimo procesas buvo atliekamas tik atvejui $\mathrm{C} 3$, o kitais atvejais optimalus sprendinys buvo gautas pirmojoje iteracijoje, nes skaičiavimas buvo vykdomas tik su programa MaxFoptl (klumpamoji galia su MatrixFrame programa nebuvo skaičiuota), bei standumo matrica $\boldsymbol{K}$ viso optimizavimo metu nekito (skirtingai nei projektiniame uždavinyje). Šiame pavyzdyje matyti, jog klumpamosios galios ịvertinimas turi didelę itaką tikslo funkcijos (TF) reikšmei. C3 skaičiavimo atveju TF yra mažiausia. TF reikšmés skirtumas tarp C3 ir C2 yra 44\%, o tarp C3 ir C1 - 112\%.

\subsection{Trečiojo skyriaus išvados}

1. Prisitaikančių konstrukcijų optimalaus projektavimo metodikos praktinis įdiegimas turi būti grindžiamas ne tik teoriniais patobulinimais, sukurtais naujais matematiniais modeliais, bet ir glaudžia sąsaja su egzistuojančiais konstrukcijų projektavimo paketais. Tuo būdu įmanoma išvengti itin teoretizuotų konstrukcijų optimizavimo metodų atotrūkio nuo realaus, pagristo normatyviniais dokumentais projektavimo. 
2. Sudarytų pagrindinių optimizavimo uždavinių su stiprumo, standumo ir klumpamosios galios apribojimais sprendimo dalis, liečianti klumpamają galią, yra perkeliama projektavimo programai su įdiegtais projektavimo standartais.

3. Sprendimo procesas tampa išimtinai tik iteracinis.

4. Projektavimo programos išeities duomenimis tampa ir optimizavimo uždavinio sprendimo metu gautos liekamosios irąžos ir poslinkiai, t. y. atsižvelgiama i plastinių deformacijų ittaką.

5. Siūlomi optimizavimo uždavinių sprendimo būdai leidžia realizuoti ir diskretinio optimizavimo principus. Tokiu būdu prisitaikomumo teorija tampa apibendrinančiu irankiu vykdant tamprių-plastinių konstrukcijų skaičiavimą ir optimizavimą ivairių apkrovų atvejais.

6. Sukurta metodika leidžianti statybos inžinerijos praktikoje sutinkamą judamos ar vienkartes apkrovos tipą ir apkrovos derinius interpretuoti kaip KKA atveji. 


\section{4}

\section{Sukurtoji programinè iranga}

Matematinio programavimo teorija, plačiai paplitusi kaip ekstreminių uždavinių sprendimo metodas, talkina prisitaikomumo teorijos optimizavimo uždavinių nagrinejjimui nuo jų matematinių modelių sudarymo iki skaitinio sprendinio rezultatų. Disertacijoje uždaviniai spręsti taikant Rozeno projektuojamuju gradientų metodą. Būtent Rozeno projektuojamuju gradientų metodo praktinei programinei realizacijai ir skirtas šis skyrius. Jame aptariami netiesinio programavimo taikymo ypatumai, bei Rozeno algoritmo pagrindu autoriaus sukurtos netiesinio optimizavimo programos M0opt1 bei MaxFopt1.

Skyriaus tematika paskelbtas vienas autoriaus straipsnis (Atkočiūnas et al. 2007b).

\subsection{Rozeno projektuojamuju gradientų algoritmas}

Netiesinio programavimo Rozeno projektuojamuju gradientu algoritmas yra pakankamai universalus (Bazaraa et al. 2004; Čyras ir Atkočiūnas 1984; Atkočiūnas 1994, Čyras et al. 2004). Ji galima taikyti, kai tikslo funkcija, apribojimai yra tiesiniai arba netiesiniai. Projektiniame (3.1)-(3.5) ir patikrinamajame (3.6)(3.10) uždaviniuose tikslo funkcija ir apribojimai yra tiesiniai, todèl toliau bus iliustruojamas Rozeno algoritmo taikymas šiam atvejui. Bendrai tiesinio programavimo iškilas uždavinys užrašomas: 
rasti

$$
\max \mathscr{F}(\boldsymbol{x})
$$

kai

$$
\varphi_{i}(\boldsymbol{x})=\boldsymbol{a}_{i}^{T} \boldsymbol{x} \leq 0, i=1,2, \ldots, l, i \in I .
$$

Kadangi funkcija $\varphi_{i}(\boldsymbol{x})$ - tiesinè, tai jos gradientas $\nabla \varphi_{i}(\boldsymbol{x})=\boldsymbol{a}_{i}$; čia $\boldsymbol{a}_{i}-$ $n$-matis koeficientų prie nežinomuju vektorius-stulpelis. Tiesinių apribojimų (4.2) atveju aktyvinių apribojimų gradientų matrica žymima $\boldsymbol{A}_{\kappa}$ t. y.,

$$
\nabla \boldsymbol{\Phi}(\boldsymbol{x})=\boldsymbol{A}_{\kappa}=\left[\begin{array}{llllll}
\boldsymbol{a}_{1} & \boldsymbol{a}_{2} & \ldots & \boldsymbol{a}_{i} & \ldots & \boldsymbol{a}_{\kappa}
\end{array}\right] .
$$

Čia $\boldsymbol{A}_{\kappa}-(n \times \kappa)$ - matè matrica, kur $n$ - Euklido erdvès $E^{n}$ matas, o $\kappa$-aktyvinių apribojimu skaičius. Aktyviniais vadinami tokie apribojimai, kurie tenkinami kaip lygybès $\left(\varphi_{i}\left(\boldsymbol{x}^{k}\right)=0, i \in I\right.$.). Vektoriai iš $n$-matès erdvès, tenkinantys (4.2) sąlygas kaip lygybes, sudaro $(n \times \kappa)$-mati darini, žymimą $G^{\kappa}$. Judejjimas iš Euklido erdvès $E^{n}$ taško $\boldsymbol{x}^{k}$ vyksta vektoriaus $\boldsymbol{P}_{\kappa} \nabla \mathscr{F}\left(\boldsymbol{x}^{k}\right)$, apskaičiuoto pagal formulę:

$$
\boldsymbol{P}_{k} \nabla \mathscr{F}\left(\boldsymbol{x}^{k}\right)=\left(\boldsymbol{I}-\nabla \boldsymbol{\Phi}\left(\boldsymbol{x}^{k}\right) \boldsymbol{V}_{k}\left(\boldsymbol{x}^{k}\right) \nabla \boldsymbol{\Phi}^{T}\left(\boldsymbol{x}^{k}\right)\right) \nabla \mathscr{F}\left(\boldsymbol{x}^{k}\right)
$$

kryptimi (4.1 pav.). $\boldsymbol{I}-(n \times n)$-matè vienetinè matrica, $\nabla \mathscr{F}\left(\boldsymbol{x}^{k}\right)$ - tikslo funkcijos gradientas, o $(\kappa \times \kappa)$-matè matrica $\boldsymbol{V}_{x}\left(\boldsymbol{x}^{k}\right)$ išreiškiama taip: $\boldsymbol{V}_{x}\left(\boldsymbol{x}^{k}\right)=$ $\left(\nabla \boldsymbol{\Phi}^{T}\left(\boldsymbol{x}^{k}\right) \nabla \boldsymbol{\Phi}\left(\boldsymbol{x}^{k}\right)\right)^{-1} . \boldsymbol{P}_{\kappa}-$ projektyvine matrica. Taip randamas vektorius $\boldsymbol{x}^{k+1}=\boldsymbol{x}^{k}+\tau^{\prime} \boldsymbol{P}_{\kappa} \nabla \mathscr{F}\left(\boldsymbol{x}^{k}\right), \quad$ čia eilinès iteracijos ejimo žingsnis $\tau^{\prime}=\min \left\{\tau^{\prime} \mid \tau^{\prime}>0, i=\kappa+1, \kappa+2, \ldots, l\right\}$. Tik tokiu atveju vektorius $x^{k+1}$ „neišeina“ iš leistinosios srities $\mathscr{L}=\left\{\boldsymbol{x} \mid \varphi_{i}(\boldsymbol{x}) \leq 0, \quad i=1,2, \ldots, l\right\}$. Jeigu leistinojo intervalo viduje $0<\tau<\tau^{\prime}$ nèra tokio vektoriaus, kuriam tikslo funkcijos reikšmè būtų didesnè, negu taške $\boldsymbol{x}^{k+1}$, laikoma, kad $\widetilde{\boldsymbol{x}}^{k+1}=\boldsymbol{x}^{k+1}$ ir skaičiavimo procesas tęsiamas. Jeigu $\nabla \mathscr{F}^{T}\left(\boldsymbol{x}^{k}\right) \boldsymbol{P}_{\kappa} \nabla \mathscr{F}\left(\boldsymbol{x}^{k+1}\right)<0$, tai tikslo funkcija pasiekia savo maksimumą spindulyje tarp taškų $\boldsymbol{x}^{k}$ ir $\boldsymbol{x}^{k+1}$. 


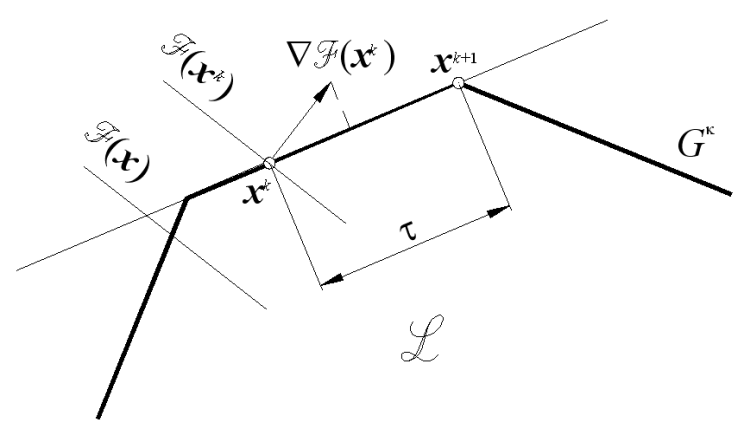

4.1 pav. Rozeno algoritmas, esant tiesiniams apribojimams

Fig. 4.1. Rozen algorithm in case of linear constraints

Taip apskaičiuojamas naujas žingsnis:

$$
\tau^{\prime \prime}=\tau^{\prime} \frac{\nabla \mathscr{F}^{T}\left(\boldsymbol{x}^{k}\right) \boldsymbol{P}_{\kappa} \nabla \mathscr{F}\left(\boldsymbol{x}^{k}\right)}{\nabla \mathscr{F}^{T}\left(\boldsymbol{x}^{k}\right) \boldsymbol{P}_{\kappa} \nabla \mathscr{F}\left(\boldsymbol{x}^{k}\right)-\nabla \mathscr{F}\left(\boldsymbol{x}^{k}\right) \boldsymbol{P}_{\kappa} \nabla \mathscr{F}\left(\boldsymbol{x}^{k+1}\right)} \cdot
$$

Šiuo atveju $\boldsymbol{x}^{k+1}$ randamas pagal formulę: $\boldsymbol{x}^{k+1}=\boldsymbol{x}^{k}+\tau^{\prime \prime} \boldsymbol{P}_{\kappa} \nabla \mathscr{F}\left(\boldsymbol{x}^{k}\right)$. Vektorius $\boldsymbol{x}$ laikomas sprendiniu, jeigu tenkinamos sąlygos:

$$
\begin{gathered}
\boldsymbol{P}_{\kappa} \nabla \mathscr{F}(\boldsymbol{x})=\mathbf{0}, \\
\boldsymbol{V}_{x}(\boldsymbol{x}) \nabla \boldsymbol{\Phi}^{T}(\boldsymbol{x}) \nabla \mathscr{F}(\boldsymbol{x}) \leq \mathbf{0} .
\end{gathered}
$$

Norint mechaniškai teisingai interpretuoti sąlygas (4.6), tenka pasinaudoti Kuno ir Takerio salygomis (Bazaraa et al. 2004). Taip pasielgta darbe (Храптович ir Аткочюнас 2001), kuriame parodyta, kad lygtis (4.6) yra deformaciju darnos lygtis, o kairioji nelygybès (4.7) pusè, paimta absoliutiniu dydžiu yra plastinių daugikliu vektorius $\lambda$ :

$$
\lambda=\left|\boldsymbol{V}_{x}(\boldsymbol{x}) \nabla \boldsymbol{\Phi}^{T}(\boldsymbol{x}) \nabla \mathscr{F}(\boldsymbol{x})\right| .
$$

\subsection{Rozeno algoritmo valdymo specifika ir patirtis}

Kompiuterineje algoritmo realizacijoje yra naudojamos valdymo konstantos, kuriomis yra nusakomas algoritmo veikimas bei sprendinio $\boldsymbol{x}^{*}$ (optimalaus vektoriaus) konvergavimo kriterijai. Nuo šių konstantų parinkimo priklauso ar op- 
timizavimo procesas bus sékmingas ir kaip greitai t. y. per kiek iteraciju bus gautas optimalus sprendinys.

Algoritme naudojama aktyvių apribojimų sąvoka. Tai tokie apribojimai kurie tenkinami kaip lygybès.

$$
\varphi_{i}(x)=0 \text {. }
$$

Tačiau programavimo prasme apribojimo skaitinès reikšmès, kai naudojami slankiojo kablelio kintamieji, retai kada bus lygios nuliui ir dèl to algoritmas neveiks t. y. nebus rasta jokių aktyviu apribojimų netgi jei, pavyzdžiui, bandysime palyginti tokią reikšmę kaip $1 e^{-30}$ su $0: 1 e^{-30} \neq 0$. Nors jei apribojime naudojami dydžiai yra $1 e^{5} \div 1 e^{6}$ eilès, pavyzdžiui ribiniai momentai, tai galima interpretuoti, kad aktyvaus apribojimo reikšmè lygi nuliui. Todèl yra naudojama teigiama konstanta $\delta$ (programų M0opt1 ir MaxFopt1 rezultatų failuose žymima DELTA, 4.2 pav.), kuri nusako kada galime laikyti apribojimus (4.9) aktyviais:

$$
\left|\varphi_{i}(x)\right| \leq \delta .
$$

Skaičiavimuose naudojamos $\delta$ reikšmès yra $1 e^{-3} \div 1 e^{-5}$ eilès dydžiai laikant, kad apribojimo (4.9) reikšmès artimos $1 \div 10$ eilès dydžiams (t. y. apribojimai yra normalizuoti). Konstanta $\delta$ yra viena iš svarbiausių Rozeno algoritmo valdymo konstantų. Nuo jos parinkimo priklauso sékmingas optimizavimo procesas, todèl nesèkmingai vykstant optimizavimo procesui rekomenduotina pirmiausia keisti šios konstantos reikšmę ir pakartoti skaičiavimą.

Rozeno algoritmo optimalumo (Kuno ir Takerio) sąlygos (4.6)-(4.7) taip pat yra lyginamos su nuliu. Todèl yra naudojamos konstantos $\eta$ (ETA, 4.2 pav.) bei $\varepsilon$ (EPS) ir sąlygos (4.6)-(4.7) perrašomos:

$$
\begin{gathered}
\left|\boldsymbol{P}_{\kappa} \nabla \mathscr{H}(\boldsymbol{x})\right| \leq \boldsymbol{\eta}, \\
\boldsymbol{V}_{\kappa}(\boldsymbol{x}) \nabla \boldsymbol{\Phi}^{T}\left(\boldsymbol{x}^{k}\right) \nabla \mathscr{H}(\boldsymbol{x}) \leq \boldsymbol{\varepsilon} .
\end{gathered}
$$

Teigiamai konstantai $\boldsymbol{\eta}$ naudojami $1 e^{-2} \div 1 e^{-4}$ eilès reikšmès. Konstanta $\boldsymbol{\varepsilon}$ gali buti tiek teigiama tiek neigiama. Jos reikšme $1 e^{-2} \div 1 e^{-4}$. Optimizavimo metu rezultatų faile yra išvedamos realios (faktinès) didžiausios sąlygų (4.11) bei (4.12) reikšmès, kurios atitinkamai žymimos ETAF ir EPSF. Pagal jas galima orientuotis kiek arti optimalaus sprendinio yra tam tikros iteracijos sprendinys $\boldsymbol{x}$. Optimaliam sprendiniui turi būti $|\mathbf{E T A F}| \leq \eta$ ir $\mathbf{E P S F} \leq \varepsilon$. Jei matome, kad optimizavimo algoritmas nekonverguoja ir tikslo funkcijai pasiekus tam tikrą reikšmę niekaip neberandama optimalesnè reikšmé ir „algoritmas užsiciklina“, 
tai reikètų atkreipti dèmesi i konstantas $\eta$ ir $\varepsilon$, bei ETAF ir EPSF. Jei ETAF ir EPSF skiriasi nuo $\eta$ ir $\varepsilon$, pavyzdžiui, $10 \div 20 \%$, tai vertètų sustabdyti optimizavimo procesą ir priskyrus reikšmes $\eta=\mathbf{E T A F}+\mathbf{E T A F} \cdot 0,01 \mathrm{ir} / \mathrm{arba}$ $\varepsilon=\mathbf{E P S F}+\mathbf{E P S F} \cdot 0,01$ pakartoti optimizavimo procesą.

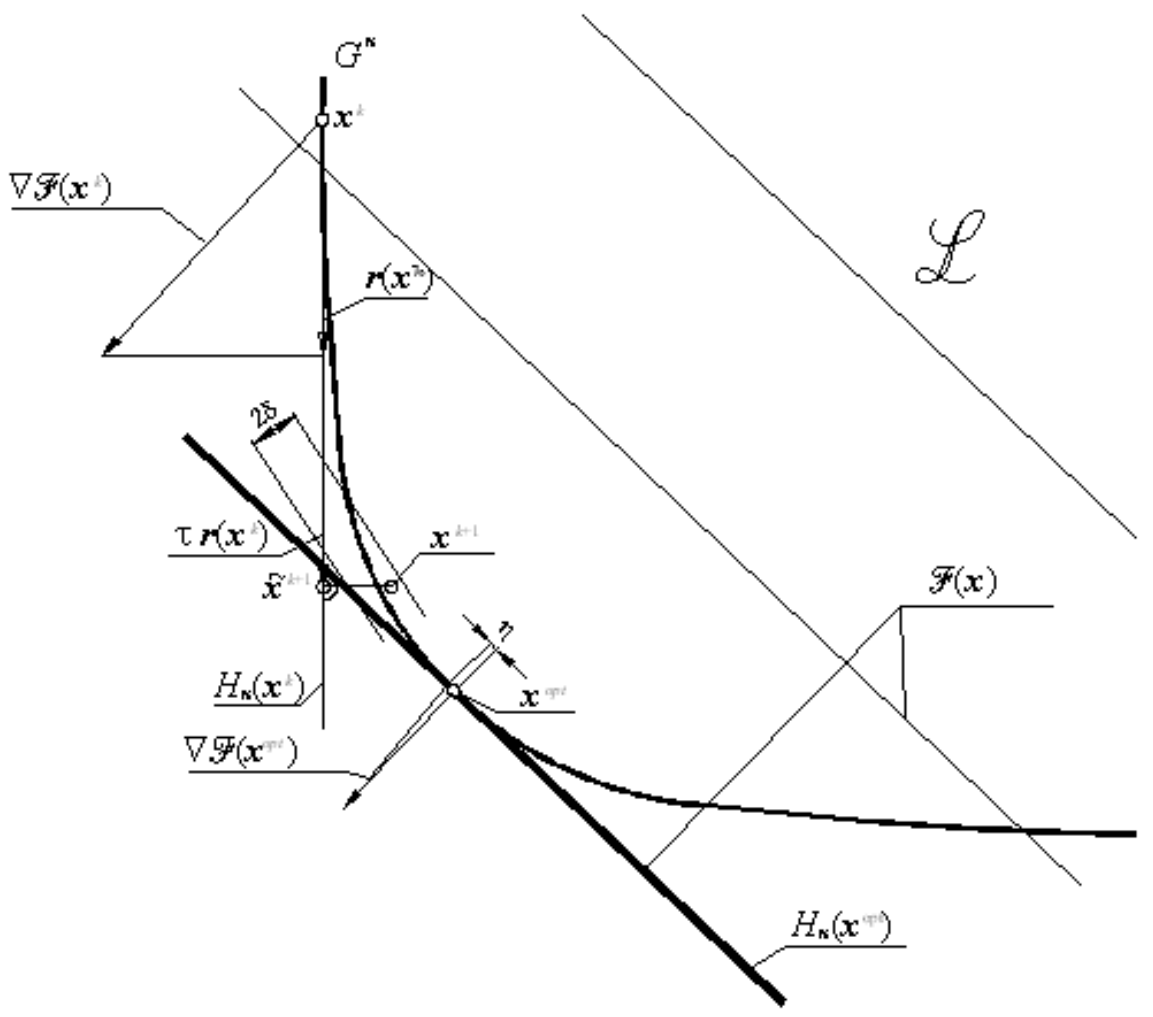

4.2 pav. Rozeno algoritmas, $\delta$ ir $\eta$ konstantų geometrinė interpretacija

Fig. 4.2. Rozen algorithm, geometrical interpretation for constants $\delta$ and $\eta$

Rozeno algoritmo ejjimo žingsnio $\tau>0$ mažiausią reikšmę nusako teigiama konstanta TMZ. Ėjimo žingsnis gali pradèti neapibrěžtai mažèti baigiantis optimizavimo procesui t. y. arti optimalaus sprendinio. Tai gali nulemti per griežta (maža) konstantos $\eta$ reikšmè. Ją reikètų padidinti arba tarpini sprendini priimti kaip optimalų. Jei padidinus reikšmę $\eta$ uždavinys vis tiek nekonverguoja, reikè- 
tų pakeisti kitas konstantas. Konstantos rekomenduotinos reikšmès yra $1 e^{-4} \div 1 e^{-5}$.

Teigiama konstanta ALIET nusako kiek optimizavimo proceso metu gali sumažèti (jei vykdoma maksimizacija) arba padidèti (jei vykdoma minimizacija) tikslo funkcijos $\mathscr{F}(\boldsymbol{x})$ reikšmè. Nors Rozeno algoritmas garantuoja tik tikslo funkcijos didejimą (kai vykdoma maksimizacija) arba tik mažejimą (kai vykdoma minimizacija) viso optimizavimo metu, tačiau praktinèje algoritmo realizacijoje nesėkmingai parinkus naują tašką $\boldsymbol{x}^{k+1}$ tenka grižti atgal ,priešinga optimizavimui" kryptimi ir tęsti optimizavimą. Grį̌imo maksimalų dydị ir nusako konstanta ALIET, kurios rekomenduotina reikšmė yra $1 e^{-4}$ eilès dydis.

Šalia anksčiau paminètų Rozeno algoritmo konstantų naudojamos normalizuojančios konstantos $C_{S 0}, C_{\lambda}, C_{u}$ ir $C_{F}$. Šių konstantų paskirtis normalizuoti (padaryti artimas vienetui) apribojimų reikšmes. Tai reikalinga tam, kad apribojimų reikšmès būtų vienos eilès dydis artimas vienetui, bei tam, kad būtų korektiška palyginimo operacija su konstanta $\delta$. Prisitaikančių konstrukcijų projektinio uždavinio matematinis modelis ivvertinus valdymo ir normalizuojančias konstantas užrašomas:

rasti

$$
\min \left(\boldsymbol{L}^{T} \boldsymbol{S}_{0}+\lambda_{j}^{T} \boldsymbol{\varphi}_{j}\right)
$$

kai

$$
\begin{gathered}
\boldsymbol{\varphi}_{j}=\left(C_{S 0} \boldsymbol{\Gamma}\right) \boldsymbol{S}_{0}-\boldsymbol{\Phi}\left(\left(C_{\lambda} \boldsymbol{G}\right) \boldsymbol{\lambda}+\boldsymbol{S}_{e j}+\boldsymbol{S}_{e c}\right) \geq \delta, \\
\lambda_{j} \geq \delta, \lambda=\sum_{j} \lambda_{j}, j \in J, \\
\boldsymbol{S}_{\max } / C_{S 0}-\boldsymbol{S}_{0} \geq \delta, \\
\boldsymbol{S}_{0}-\boldsymbol{S}_{\min } / C_{S 0} \geq \delta, \\
C_{u} \boldsymbol{u}_{\max }-C_{u}\left(\left(C_{\lambda} \boldsymbol{H}\right) \lambda+\boldsymbol{u}_{e j}+\boldsymbol{u}_{e c}\right) \geq \delta, \\
C_{u}\left(\left(C_{\lambda} \boldsymbol{H}\right) \lambda+\boldsymbol{u}_{e j}+\boldsymbol{u}_{e c}\right)-C_{u} \boldsymbol{u}_{\min } \geq \delta .
\end{gathered}
$$

Patikrinamojo uždavinio matematinis modelis įvertinus visas konstantas užrašomas: 
rasti

$$
\max \left(\boldsymbol{T}_{\text {sup }}^{T} \boldsymbol{F}_{\text {sup }}-\boldsymbol{T}_{\text {inf }}^{T} \boldsymbol{F}_{\text {inf }}-\lambda_{j}^{T} \boldsymbol{\varphi}_{j}\right)
$$

kai

$$
\begin{gathered}
\boldsymbol{\varphi}_{j}=\left(\boldsymbol{S}_{0}-\boldsymbol{\Phi}\left(\left(C_{\lambda} \boldsymbol{G}\right) \lambda+\boldsymbol{S}_{e j}+\boldsymbol{S}_{e c}\right)\right) / C_{F} \geq \delta, \\
\lambda_{j} \geq \delta, \lambda=\sum_{j} \lambda_{j}, j \in J, \\
\boldsymbol{F}_{\text {sup }} \geq \delta, \boldsymbol{F}_{\text {max }} / C_{F}-\boldsymbol{F}_{\text {sup }} \geq \delta, \\
-\boldsymbol{F}_{\text {inf }} \geq \delta, \boldsymbol{F}_{\text {sup }}-\boldsymbol{F}_{\text {min }} / C_{F} \geq \delta \\
C_{u} \boldsymbol{u}_{\text {max }}-C_{u}\left(\left(C_{\lambda} \boldsymbol{H}\right) \lambda+\boldsymbol{u}_{e j}+\boldsymbol{u}_{e c}\right) \geq \delta, \\
C_{u}\left(\left(C_{\lambda} \boldsymbol{H}\right) \lambda+\boldsymbol{u}_{e j}+\boldsymbol{u}_{e c}\right)-C_{u} \boldsymbol{u}_{\min } \geq \delta .
\end{gathered}
$$

Programų M0opt1 bei MaxFopt1 rezultatų failuose normalizuojančios konstantos $C_{S 0}, C_{\lambda}, C_{u}$ ir $C_{F}$ žymimos atitinkamai MODAUG, LIAMDAUG, UDAUG ir FDAUG.

Rašant netiesinio optimizavimo uždavinius realizuojančias programas vienas iš esminių programavimo etapu yra tikslo funkcijos ir gradientų formavimas. Paprogramès realizuojančios gradientų formavimą yra pateiktos prieduose A ir B.

\subsection{Pradinių duomenų formavimas programai M0opt1}

Pirma konstantu grupé (sveikojo tipo skaičiai):

IEIL - rèmo diskretinio modelio laisvumo laipsnis (nustato visos diskretinès sistemos pusiausvyros lygčių skaičiu);

MM - įrąžu, esančių nagrinejjamo rèmo diskretinio modelio pusiausvyros lygtyse, skaičius t. y. pusiausvyros lygčių koeficientų matricos $\boldsymbol{A}$ stulpelių skaičius;

ITASK - diskretinio modelio skaičiuojamujų pjūvių skaičius;

MOMSIZE - lenkimo momentų $M$, esančių nagrinèjamo rẻmo diskretinio modelio pusiausvyros lygtyse, skaičius; 
FSIZE - apkrovų skaičius;

XMOSIZE - optimizuojamų parametrų skaičius;

BSUMU - 0 jeigu ịvertinami tik liekamieji momentai, bet koks skaičius jei ịvertinami suminiai poslinkiai t. y. jei apribojami suminiai poslinkiai (liekamieji + tamprūs);

BDSEP - 0 jeigu matrica $\boldsymbol{D}$ įvedama pradiniame duomenų faile, bet koks skaičius jei įvedama atskirame duomenų faile.

Antra konstantu grupe (Rozeno algoritmo valdymo konstantos; realiojo tipo skaičiai; Karkauskas et al., 1995, lentele 4.5):

EPS - skaičius parodantis kada plastines deformacijas galime laikyti lygias nuliui;

DELTA - skaičius parodantis kada takumo salygos - nelygybès laikomos lygybèmis;

ETA - optimalaus taško maksimali tikslo funkcijos gradiento projekcijos reikšmé;

TMZ - minimaliausia žingsnio $\tau$ reikšmè;

ALIET - skaičius nusakantys kiek maksimaliai gali sumažèti tikslo funkcija;

Normalizuojančios konstantos:

LIAMDAUG - daugiklius $\lambda_{i}$ normalizuojanti konstanta. Rekomenduotinas 0,01 eilès dydis.

UDAUG - liekamuosius poslinkius $\boldsymbol{u}_{r}$ normalizuojanti konstanta. Jei yra tikètini centimetrų eilès dydžiai, tai šiai konstantai rekomenduotinos reikšmès 10-30 M0DAUG - ribini momentą $\boldsymbol{M}_{0}$ normalizuojanti konstanta. Rekomenduotinos reikšmès $100-300$.

Pastaba: visos konstantos, išskyrus EPS turi būti tik teigiamos. EPS gali būti ir neigiama.

Matricos ir vektoriai.

Matricos ịvedamos stulpeliais, visų ịvedamų dydžių dimensijos turi būti N ir m.

A(IEIL,MM) - pusiausvyros lygčių koeficientų matrica;

D(MM, MM) - pasiduodamumo matrica;

XSV(XMOSIZE) - optimalumo kriterijaus svorio koeficientų vektorius;

MORIB(XMOSIZE*2) - optimalumo kriterijaus ribiniu reikšmių vektorius;

AK1(ITASK, XMOSIZE) - $\boldsymbol{M}_{0}$ konfigūracijos matrica, kuri parodo kuriame konstrukcijos pjūvyje, kuris ribinis momentas veikia;

FSUPFINF(IEIL, FSIZE*2) - apkrovų ribų matrica; 
CK(MM) - ribinių momentų ir ribinių ašinių jègų santykių vektorius;

MNKFG(ITASK, 2) - pjūviuose veikiančiu iražžų $M$ ir N sąryšio matrica. Pirmame stulpelyje nurodomas pjūvyje veikiančio momento indeksas (matricos $\boldsymbol{A}$ atitinkantį tą momentą stulpelio indeksas), o antrame stulpelyje atitinkamai tame pjūvyje veikiančios ašinès jègos indeksas.

USUMRIB(IEIL*2) - ribinių liekamujų (arba suminių, jei BSUMU nelygu 0) poslinkių reikšmių vektorius;

X(4*ITASK*IVIRS+XMOSIZE) - pradinis nežinomujų vektorius;

PC(MM) - tamprios ịrąžos nuo pastovios apkrovos (jei BSUMU=0 ịvedami nuliai);

UEPC(IEIL) - tamprūs poslinkiai nuo pastovios apkrovos (jei BSUMU=0 įvedami nuliai);

Sveikojo tipo skaičių matrica yra MNKFG, likusios - realiojo tipo.

\subsection{Pradinių duomenų formavimas programai MaxFopt1}

Pirma konstantu grupé (sveikojo tipo skaičiai):

IEIL - rèmo diskretinio modelio laisvumo laipsnis (nustato visos diskretinès sistemos pusiausvyros lygčių skaičių);

MM - įrąžu, esančių nagrinejjamo remo diskretinio modelio pusiausvyros lygtyse, skaičius t. y. pusiausvyros lygčių koeficientų matricos $\boldsymbol{A}$ stulpelių skaičius;

ITASK - diskretinio modelio skaičiuojamujų pjūvių skaičius;

MOMSIZE - lenkimo momentų $M$, esančių nagrinejjamo rèmo diskretinio modelio pusiausvyros lygtyse, skaičius;

FSIZE - optimizuojamų apkrovų skaičius.

Antra konstantu grupe (Rozeno algoritmo valdymo konstantos; realiojo tipo skaičiai; Karkauskas et al., 1995, lentele 4.5):

EPS - skaičius parodantis kada plastines deformacijas galime laikyti lygias nuliui;

DELTA - skaičius parodantis kada takumo salygos - nelygybès laikomos lygybèmis;

ETA - optimalaus taško maksimali tikslo funkcijos gradiento projekcijos reikšmé;

TMZ - minimaliausia žingsnio $\tau$ reikšmè;

ALIET - skaičius nusakantys kiek maksimaliai gali sumažèti tikslo funkcija; 
Normalizuojančios konstantos:

LIAMDAUG - daugiklius $\lambda_{i}$ normalizuojanti konstanta. Rekomenduotinas 0.01 eilès dydis.

UDAUG - liekamuosius poslinkius $\boldsymbol{u}_{r}$ normalizuojanti konstanta. Jei yra tikètini centimetrų eilès dydžiai, tai šiai konstantai rekomenduotinos reikšmès 10-30 FDAUG - apkrovų ribas $\boldsymbol{F}_{\text {sup }}, \boldsymbol{F}_{\text {inf }}$ normalizuojanti konstanta. Rekomenduotinos reikšmès $100-300$

Pastaba: visos konstantos, išskyrus EPS turi būti tik teigiamos. EPS gali būti ir neigiama.

Matricos ir vektoriai.

Matricos įvedamos stulpeliais, visų įvedamų dydžių dimensijos turi būti $\mathrm{N}$ ir $\mathrm{m}$.

A(IEIL,MM) - pusiausvyros lygčių koeficientų matrica;

D(MM, MM) - pasiduodamumo matrica;

TFSV(FSIZE*2) - optimalumo kriterijaus svorio koeficientų vektorius;

FRIB(FSIZE*2) - optimalumo kriterijaus ribiniu reikšmių vektorius;

FKFG(FSIZE) - apkrovos konfigūracijos vektorius, kuris parodo kurias pusiausvyros lygčių eilutes atitinka optimizuojamos jègos;

SRIB(MM) - ribiniu ịrąžų $M_{0}, N_{0}$ vektorius;

MNKFG(ITASK, 2) - pjūviuose veikiančių įrąžu $M$ ir $N$ sąryšio matrica. Pirmame stulpelyje nurodomas pjūvyje veikiančio momento indeksas (matricos $\boldsymbol{A}$ atitinkantį tą momentą stulpelio indeksas), o antrame stulpelyje atitinkamai tame pjūvyje veikiančios ašinès jègos indeksas.

URRIB(IEIL*2) - ribinių liekamujų poslinkiu reikšmių vektorius;

X(4*ITASK*2^FSIZE +FSIZE*2) - pradinis nežinomuju vektorius;

\subsection{Ketvirtojo skyriaus išvados}

1. Sukurtų optimizavimo programų naudojimas turi žymių privalumų prieš analogiškas matematiniuose paketuose įdiegtas programas, nes pastarosios neleidžia pilnai valdyti optimizavimo proceso t. y. jos yra ,juodosios dèžès“, bei negali realizuoti KKA apkrovos, kai pastaroji užduota tik kitimo ribomis.

2. Netiesinių optimizavimo programų skaičiavimo rezultatų tikslumas ir konvergavimas priklauso nuo užsiduotų valdymo konstantų. Tokių uždavinių sprendimas reikalauja patirties ir algoritmo valdymo igūdžių. 


\section{Prisitaikančių tampriujų-plastinių simetrinių plokščių apkrovos optimizavimas}

Skyriuje nagrinëjamas tamprios-plastinès simetrinės plokštės apkrautos KKA. patikrinamasis uždavinys. Pasiūlytas naujas Rozeno projektuojamuju gradientų pagrindu suformuluotas patikrinamojo uždavinio sprendimo algoritmas kombinuojantys Mizeso ir Treska takumo salygas. Pasitelkiamos idealiai tampriaiplastinių konstrukcijų techniškosios skaičiavimo teorijos prielaidos (maži poslinkiai ir deformacijos).

Skyriaus tematika paskelbtas vienas autoriaus straipsnis (Venskus et al. 2010).

\subsection{Diskretinès plokštės irąžos ir deformacijos}

Polinèje koordinačių sistemoje $\boldsymbol{x}=(\rho, \theta)^{T}$ simetriškos apvalios plokštès (5.1 a pav.) diskretinis modelis gaunamas suskaidžius ją $\mathfrak{i} k=1,2, \ldots, s \quad(k \in K)$ žiedinių baigtinių elementų su $s_{k}$ mazginių taškų $l=1,2, s_{k}=3(l \in \mathscr{L})(1$ ir 3 elemento mazgai yra pagrindiniai) $(5.1 \mathrm{~b}$ pav.). Polinès koordinačių sistemos 
pradžia yra plokštės centre. Užtenka ištirti tik vieną tokios plokštès spinduli, nes iražos ir poslinkiai nepriklauso nuo koordinates $\theta$.

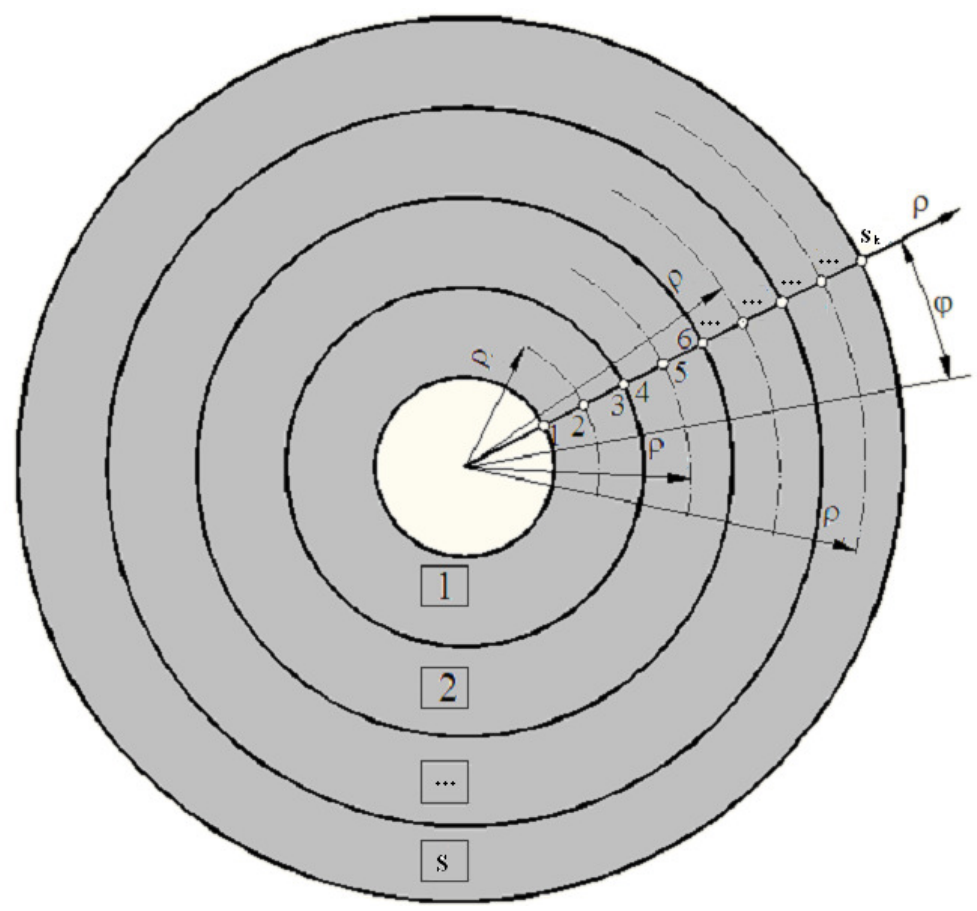

a)

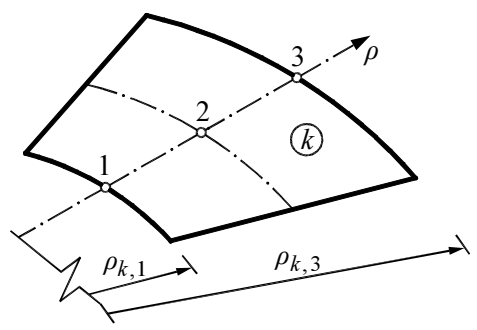

b)

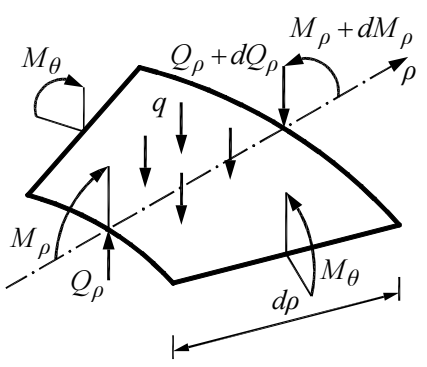

c)

5.1 pav. Apvalios plokštės geometrija (a), baigtinis elementas (b) ir teigiamos irąžu kryptys (c)

Fig. 5.1. a) The geometry of a round plate; b) the finite element; c) the positive directions of internal forces 
Todèl jų diskretizacijai naudojamas antros eilès žiedinis elementas (įražos aproksimuojamos antro laipsnio polinomais) su trimis mazginiais taškais, išdèstytais viename spindulyje $\rho$. Baigtiniai elementai numeruojami išilgai spindulio nuosekliai, pradedant nuo plokštès centro. Apkrova gali būti: paskirstyta baigtinio elemento paviršiuje, žiedu paskirstyta sutelktoji jèga. Medžiagos fiziniai parametrai (tamprumo modulis $E$ ir Puasono koeficientas $v$ ), plokštès storis $t$ ir paskirstytos apkrovos intensyvumas $q$ baigtiniame elemente yra pastovūs. Tampriose plastiškose plokštėse, taikant pusiausvirujų baigtinių elementų metodą (Belytschko 1972; Belytschko et al. 2000; Gallager 1975; Faccioli and Vitiello 1973; Kalanta 1995), ieškomos įrąžų funkcijos gali turèti trūkių (ties pagrindiniais mazgais). Todèl kiekvienas baigtinis elementas turi „savo“ pagrindinius mazgus, ir skaičiuojamieji pjūviai gali būti indeksuojami dvigubu indeksu $k l$ $(k \in K, l \in \mathscr{L})$ arba bendru visiems plokštès diskretinio modelio skaičiuojamiesiems pjūviams indeksu $i=1,2, \ldots, \zeta=s \times v \quad(i \in I)$.Elemento $k$ momentų vektorius yra:

$$
\begin{aligned}
& \boldsymbol{M}_{k}=\left(M_{\rho, k 1}, M_{\theta, k 1}, M_{\rho, k 2}, M_{\theta, k 2}, M_{\rho, k 3}, M_{\theta, k 3}\right)^{T} \\
& =\left(\boldsymbol{M}_{k 1}, \boldsymbol{M}_{k 2}, \boldsymbol{M}_{k 3}\right)^{T}=\left(\boldsymbol{M}_{k l}\right)^{T} .
\end{aligned}
$$

Čia $\boldsymbol{M}_{k 1}=\left(M_{\rho, k l}, M_{\Theta, k l}\right)^{T}$, indeksai $\rho$ ir $\Theta$ žymi radialinius ir žiedinius momentus, teigiamos jų kryptys pavaizduotos $5.1 \mathrm{c}$ pav.

Lenkimo momentų aproksimacijos funkcijos, panaudojant $k$-jo elemento irąžų aproksimacijos matricą $N_{k}(\rho)$, yra tokios:

$$
\boldsymbol{M}_{k}(\rho)=\boldsymbol{N}_{k}(\rho) \boldsymbol{M}_{k} .
$$

Funkcijos (5.2) tokios, kad plokštès elemento pusiausvyros lygtis

$$
\begin{gathered}
\left(-\frac{d^{2}}{d \rho^{2}}-\frac{2}{\rho} \frac{d}{d \rho}\right) M_{\rho}+\frac{1}{\rho} \frac{d}{d \rho} M_{\Theta}=q \quad \text { arba } \\
\qquad \mathbf{M}(\rho)=q
\end{gathered}
$$

nèra tapatybiškai tenkinama. Todèl diskretinio modelio pusiausvyra yra užtikrinama plokštès elementams ir pagrindiniams mazgams (Karkauskas 1994). Irašius i lygti (5.3) išraišką (5.2) ir atlikus diferencijavimo veiksmus gaunama algebrine baigtinio elemento pusiausvyros lygtis 


$$
\boldsymbol{A}_{k}(\rho) \boldsymbol{M}_{k}=q_{k},
$$

čia

$$
\boldsymbol{A}_{k}(\rho)=\mathscr{A} \mathbf{N}_{k}(\rho) .
$$

Paskiri elementai i sistema jungiami, rašant pusiausvyros lygtis abiem pagrindiniams gretimų elementų mazgams. Taip užtikrinamas radialinių momentų $M_{\rho}$ ir skersinių jègu $Q_{\rho}$ tolydinumas. Atsižvelgus ir i kraštines sąlygas, plokštès $m$ pusiausvyros lygčių sistema užrašoma taip:

$$
\boldsymbol{A} \boldsymbol{M}=\boldsymbol{F} \text { arba } \sum_{k} \boldsymbol{A}_{k} \boldsymbol{M}_{k}=\boldsymbol{F} .
$$

Taigi matricos $\boldsymbol{A}$ išmatavimai yra $(m \times n), n=\zeta \times 2$. Plokštès diskretinio modelio geometrinès lygtys gaunamos, panaudojus itempių galimuju pokyčiu principa:

$$
\delta \mathbf{F}^{T} \mathbf{u}=\sum_{k} \int_{A_{k}} \delta \mathbf{M}_{k}^{T}(\rho) D \mathbf{M}_{k}(\rho) d A .
$$

Pasitelkus priklausomybes (5.2) ir lygtis (5.6), gauname

$$
\sum_{k} \delta \boldsymbol{M}_{k}^{T} \boldsymbol{A}_{k}^{T} \boldsymbol{u}=\sum_{k} \delta \boldsymbol{M}_{k}^{T} \boldsymbol{D}_{k} \boldsymbol{M}_{k}
$$

Čia $k$-jo elemento simetrinè pasiduodamumo matrica $\boldsymbol{D}_{k}$ skaičiuojama pagal formulę:

$$
\left[D_{k}\right]=\int_{A_{k}} \boldsymbol{N}_{k}^{T}(\rho) \mathcal{D} \boldsymbol{N}_{k}(\rho) d A .
$$

Taip gaunamos geometrinès lygtys paskiram baigtiniam elementui:

$$
\boldsymbol{A}_{k}^{T} \boldsymbol{u}-\boldsymbol{D}_{k} \boldsymbol{M}_{k}=\mathbf{0}
$$

ir visam plokštės diskretiniam modeliui:

$$
\boldsymbol{A}^{T} \boldsymbol{u}-\boldsymbol{D M}=\mathbf{0} .
$$

Čia $\boldsymbol{D}$ - kvazidiagonalinė elementų pasiduodamumų matrica. Poslinkių vektoriaus $\boldsymbol{u}$ komponentų fizinę prasmę lemia pusiausvyros lygčiu $\boldsymbol{A M}=\boldsymbol{F}$ sudarymo sistema (eiliškumas).

Tegul plokštès deformavimosi perejimą i plastinę stadiją reglamentuoja netiesinè Mizeso-Hubero plastiškumo sąlyga 


$$
M_{\rho}^{2}-M_{\rho} M_{\Theta}+M_{\Theta}^{2} \leq\left(M_{0}\right)^{2} .
$$

Plastiškumo sąlyga tikrinama kiekviename baigtinio elemento mazginiame taške:

$$
\boldsymbol{M}_{k l}^{T} \boldsymbol{\Pi}_{k l} \boldsymbol{M}_{k l} \leq\left(M_{0 k}\right)^{2}, k \in K, l \in \mathscr{L} .
$$

Čia $\boldsymbol{\Pi}_{k l}$ - Mizeso-Hubero plastiškumo sąlygos matrica apvalios lenkiamos plokštès atveju:

$$
\boldsymbol{\Pi}_{k l}=\left[\begin{array}{cc}
1 & -0,5 \\
-0,5 & 1
\end{array}\right] \text {. }
$$

Plastiškumo sąlygos (5.13) dažnai perrašomos taip:

$$
\varphi_{k l}=\left(M_{0 k}\right)^{2}-\boldsymbol{M}_{k l}^{T} \boldsymbol{\Pi}_{k l} \boldsymbol{M}_{k l} \geq 0 .
$$

Plokštès ribinis lenkimo momentas elemento ribose pastovus: $M_{0 k}=$ const . Jeigu taikomos tiesinès Treska plastiškumo sąlygos, priklausomybè (5.15) užrašoma taip:

$$
\boldsymbol{\varphi}_{k l}=\boldsymbol{C}_{k l}-\boldsymbol{\Phi}_{k l} \boldsymbol{M}_{k l} \geq \mathbf{0} .
$$

Treska plastiškumo sąlygos matrica $\boldsymbol{\Phi}_{k l}$ yra tokia:

$$
\boldsymbol{\Phi}_{k l}=\left[\begin{array}{rr}
1 & 0 \\
0 & 1 \\
1 & -1 \\
-1 & 1 \\
-1 & 0 \\
0 & -1
\end{array}\right]
$$

Ribinių momentų reikšmių vektorius $C_{k l}$ priderintas prie matricos $\boldsymbol{\Phi}_{k l}$. Patogumo dèlei ateityje skaičiuojamuosius pjūvius indeksuosime indeksu $i=1,2, \ldots, \zeta, i \in I$. 


\subsection{Pagrindinès priklausomybès ciklinès apkrovos atveju}

Inžinerijos praktikoje dažnai reikia žinoti plokštès, patyrusios plastini deformavimą, bet nepasiekusios plastinio suirimo, itempių ir deformacijų būvị (plokštès geometrija, ribiniai momentai $M_{0}$ ir apkrova $\boldsymbol{F}$ duoti) (Jankovski ir Atkočiūnas 2008). Toks statybinès mechanikos uždavinys paprastai vadinamas analizès uždaviniu (Čyras 1983). Šiuo atveju patogu išskirti tampraus skaičiavimo momentus $M_{e}$ ir liekamuosius $M_{r}: \boldsymbol{M}_{i}=\boldsymbol{M}_{e i}+\boldsymbol{M}_{r i}, \quad i \in I$. Tamprūs momentai gali būti skaičiuojami pagal formulę $\boldsymbol{M}_{e}=\boldsymbol{\alpha} \boldsymbol{F}$. Čia $\boldsymbol{\alpha}(n \times m)-$ momentų infliuentinè matrica. Kai apkrova $\boldsymbol{F}(t)$ yra laiko $t$ funkcija, turime:

$$
\boldsymbol{M}_{i}(t)=\boldsymbol{M}_{e i}(t)+\boldsymbol{M}_{r i}, i \in I
$$

Jeigu KKA aprašoma tik savo kitimo ribomis $\boldsymbol{F}_{\text {inf }}, \boldsymbol{F}_{\text {sup }}$, galime nustatyti galimą apkrovos kombinacijų skaičių $p(j=1,2, \ldots, p ; j \in J)$ ir (5.18) perrašyti taip:

$$
\boldsymbol{M}_{i j}=\boldsymbol{M}_{e i, j}+\boldsymbol{M}_{r i}, i \in I
$$

Išsamiau apie $\boldsymbol{M}_{e i, j}$ nustatymą rašoma darbe (Pham 2003). Tuomet MizesoHubero plastiškumo sąlyga (5.15) parašoma taip:

$$
\varphi_{i j}=\left(M_{0 k}\right)^{2}-\boldsymbol{M}_{k l}^{T} \boldsymbol{\Pi}_{k l} \boldsymbol{M}_{k l} \geq 0, i \in I, j \in J .
$$

Taigi, prisitaikiusių konstrukcijų analizèje patogu išskirti liekamuosius momentus $\boldsymbol{M}_{r}$, poslinkius $\boldsymbol{u}_{r}$ ir deformacijas $\boldsymbol{\theta}_{r}=\boldsymbol{D} \boldsymbol{M}_{r}+\boldsymbol{\theta}_{p}$. Tuomet pusiausvyros (5.6) ir geometrinès (5.11) lygtys šiais kintamaisiais užrašomos:

$$
\boldsymbol{A M}_{r}=\mathbf{0} \text { arba } \sum_{k} \boldsymbol{A}_{k} \boldsymbol{M}_{r k}=\mathbf{0}
$$

ir

$$
\boldsymbol{A}^{T} \boldsymbol{u}_{r}=\boldsymbol{D} \boldsymbol{M}_{r}+\boldsymbol{\theta}_{p}
$$

Čia plastinių deformacijų vektoriaus $\boldsymbol{\theta}_{p}=\left(\boldsymbol{\theta}_{p, i}\right)$ komponentai yra skaičiuojami pagal formulę:

$$
\boldsymbol{\theta}_{p, i}=\sum_{j}\left[\nabla \boldsymbol{\varphi}_{i j}\left(\boldsymbol{M}_{e i, j}+\boldsymbol{M}_{r i}\right)\right]^{T} \lambda_{i j}, \lambda_{i j} \geq 0, i \in I, j \in J .
$$


Čia $\lambda_{i j}$ - plastinių daugiklių vektorius, $\nabla \varphi_{i j}$ - plastiškumo sąlygų (5.20) gradientų matrica.

\subsection{Analizès uždavinio matematiniai modeliai}

Analizès uždavinio statinė formuluotè sudaroma pagal papildomos energijos minimumo principą ir Mizeso plastiškumo sąlygų atveju yra:

rasti

$$
\min \frac{1}{2} \sum_{k} \boldsymbol{M}_{r k}^{T} \boldsymbol{D}_{k} \boldsymbol{M}_{r k}
$$

kai

$$
\begin{gathered}
\sum_{k} \boldsymbol{A}_{k} \boldsymbol{M}_{r k}=\mathbf{0}, k \in K, \\
\varphi_{i j}=\left(M_{0 i}\right)^{2}-\left(\boldsymbol{M}_{e i, j}+\boldsymbol{M}_{r i}\right)^{T} \boldsymbol{\Pi}_{i}\left(\boldsymbol{M}_{e i, j}+\boldsymbol{M}_{r i}\right) \geq 0, i \in K, j \in J .
\end{gathered}
$$

Optimalus uždavinio (5.24)-(5.26) sprendinys yra $\boldsymbol{M}_{r}^{*}$.

Analizès uždavinio kinematinès formuluotès matematinis modelis sudaromas pasitelkus matematinio programavimo dualumo teoriją ir yra:

rasti

$$
\begin{aligned}
\max & \left\{-\frac{1}{2} \boldsymbol{M}_{r k}^{T} \boldsymbol{D}_{k} \boldsymbol{M}_{r k}-\sum_{i} \sum_{j} \lambda_{i j} \nabla \varphi_{i j} \boldsymbol{M}_{r i}\right. \\
& \left.-\sum_{i} \sum_{j} \lambda_{i j}\left[\left(M_{0 i}\right)^{2}-\boldsymbol{M}_{i j}^{T} \boldsymbol{\Pi}_{i} \boldsymbol{M}_{i j}\right]\right\}
\end{aligned}
$$

kai

$$
\begin{gathered}
\boldsymbol{D}_{k} \boldsymbol{M}_{r k}+\sum_{j} \nabla \varphi_{i j}{ }^{T} \lambda_{k j}-\boldsymbol{A}_{\boldsymbol{k}}^{\boldsymbol{T}} \boldsymbol{u}_{r}=\mathbf{0}, \\
\boldsymbol{\lambda}_{k j} \geq \mathbf{0}, k \in K, i \in I, j \in J .
\end{gathered}
$$

Kinematinès formuluotès (5.27)-(5.29) optimalus sprendinys yra $\boldsymbol{M}_{r}^{*}, \lambda_{k j}^{*}, \boldsymbol{u}_{r}^{*}$. 
Treska plastiškumo sąlygų atveju keičiasi tik sąlygos (5.26), dabar jos būtų:

$$
\boldsymbol{\varphi}_{i j}=\boldsymbol{C}_{i}-\boldsymbol{\Phi}_{i}\left(\boldsymbol{M}_{e i, j}+\boldsymbol{M}_{r i}\right) \geq \mathbf{0} .
$$

Vektorius $\boldsymbol{C}_{i}$ apjungia atitinkamo baigtinio elemento ribinius momentus.

\subsection{Liekamujų ilinkių ir momentų infliuentinès matricos}

Jeigu analizès uždavinio statinès (5.24)-(5.26) ir kinematinès (5.27)-(5.29) formuluočių sprendinys nèra žinomas, ji galima rasti iš netiesinių lygčių sistemos:

$$
\begin{gathered}
\boldsymbol{A} \boldsymbol{M}_{r}=\mathbf{0}, \\
\boldsymbol{\varphi}_{i j}=\left(M_{0 k}\right)^{2}-\boldsymbol{M}_{i j}^{T} \boldsymbol{\Pi}_{i} \boldsymbol{M}_{i j} \\
\lambda_{i j}\left|\left(M_{0 k}\right)^{2}-\boldsymbol{M}_{i j}^{T} \boldsymbol{\Pi}_{i} \boldsymbol{M}_{i j}\right|=0, \lambda_{i j} \geq 0, \\
\boldsymbol{D} \boldsymbol{M}_{r}+\sum_{j} \nabla \varphi_{j}{ }^{T} \lambda_{j}-\boldsymbol{A}^{T} \boldsymbol{u}_{r}=\mathbf{0}, \\
\lambda_{j} \geq\left(\lambda_{i j}\right), i \in I, j \in J .
\end{gathered}
$$

Šią sistemą sudaro statinès formuluotès uždavinio (5.24)-(5.26) apribojimai ir Kuno ir Takerio sąlygos (Bazaraa et al. 2004). Kai žinomos plastinès deformacijos $\boldsymbol{\theta}_{p}^{*}$, iš sistemos:

$$
\begin{gathered}
\boldsymbol{A} \boldsymbol{M}_{r}^{*}=\mathbf{0}, \\
\boldsymbol{D M}_{r}^{*}+\boldsymbol{\theta}_{p}^{*}-\boldsymbol{A}^{T} \boldsymbol{u}_{r}^{*}=\mathbf{0}
\end{gathered}
$$

galima rasti tikrąsias $\boldsymbol{M}_{r}^{*}$, ir $\boldsymbol{u}_{r}^{*}$ reikšmes:

$$
\begin{gathered}
\boldsymbol{u}_{r}^{*}=\left(\boldsymbol{A} \boldsymbol{D}^{-1} \boldsymbol{A}^{T}\right)^{-1} \boldsymbol{A} \boldsymbol{D}^{-1} \boldsymbol{\theta}_{p}^{*}=\overline{\boldsymbol{H}} \boldsymbol{\theta}_{p}^{*}, \\
\boldsymbol{M}_{r}^{*}=\left[\boldsymbol{D}^{-1} \boldsymbol{A}^{T}\left(\boldsymbol{A} \boldsymbol{D}^{-1} \boldsymbol{A}^{T}\right)^{-1} \boldsymbol{A} \boldsymbol{D}^{-1}-\boldsymbol{D}^{-1}\right] \boldsymbol{\theta}_{p}^{*}=\overline{\boldsymbol{G}} \boldsymbol{\theta}_{p}^{*} .
\end{gathered}
$$


Pagal formules (5.36), (5.37) suskaičiuoti vektoriai $\boldsymbol{u}_{r}^{*}$, ir $\boldsymbol{M}_{r}^{*}$ visiškai sutampa su optimaliais uždavinių (5.24)-(5.26), (5.27)-(5.29) sprendiniais.

Treska plastiškumo sąlygų atveju liekamujuc poslinkių ir momentų infliuentinès matricos $\overline{\boldsymbol{H}}$ ir $\overline{\boldsymbol{G}}$ nepriklauso nuo įrąžų $\boldsymbol{M}_{j}$ :

$$
\boldsymbol{u}_{r}^{*}=\overline{\boldsymbol{H}} \boldsymbol{\Phi}^{T} \lambda^{*}=\boldsymbol{H} \lambda^{*}, \quad \boldsymbol{M}_{r}^{*}=\overline{\boldsymbol{G}} \boldsymbol{\Phi}^{T} \lambda^{*}=\boldsymbol{G} \lambda^{*} .
$$

Tai turi svarbią reikšmę, sudarant patikrinamuju uždavinių matematinius modelius: pradžioje taikomo Treska takumo sąlygos, ir tik baigiamajame uždavinio sprendimo etape - Mizeso plastiškumo kriterijus.

\subsection{Kartotinès-kintamosios apkrovos optimizavimo algoritmas}

Prisitaikiusi plokštė yra saugi plastinio suirimo atžvilgiu, tačiau ji gali netenkinti eksploatacinių reikalavimų (pavyzdžiui, standumo apribojimų). Todèl plokštės apkrovos optimizavimo uždavinyje turi būti ne tik stiprumo (plastiškumo), bet ir ilinkius ribojančios sąlygos. Uždavinio matematinis modelis Treska plastiškumo sąlygų atveju yra:

rasti

$$
\max \left(\boldsymbol{T}_{\text {sup }}^{T} \boldsymbol{F}_{\text {sup }}-\boldsymbol{T}_{\text {inf }}^{T} \boldsymbol{F}_{\text {inf }}\right),
$$

kai

$$
\begin{gathered}
\boldsymbol{\varphi}_{i j}=\boldsymbol{C}_{i}-\boldsymbol{\Phi}_{i}\left(\boldsymbol{M}_{e i, j}+\boldsymbol{G} \lambda\right) \geq \mathbf{0}, \\
\left.\lambda_{i j} \mid \boldsymbol{C}_{i}-\boldsymbol{\Phi}_{i}\left(\boldsymbol{M}_{e i, j}+\boldsymbol{G} \lambda\right)\right]=\mathbf{0}, \\
\lambda=\left(\lambda_{i j}\right), \quad i \in I, \quad j \in J, \\
\boldsymbol{u}_{\text {min }} \leq \boldsymbol{H} \boldsymbol{\lambda}+\boldsymbol{u}_{e, \text { inf }}, \\
\boldsymbol{H} \boldsymbol{\lambda}+\boldsymbol{u}_{e, \text { sup }} \leq \boldsymbol{u}_{\max } .
\end{gathered}
$$

Čia $\boldsymbol{u}_{e, \text { sup }}$ ir $\boldsymbol{u}_{e, \text { inf }}$ yra maksimalūs ir minimalūs tamprūs poslinkiai. Kartu su liekamaisiais poslinkiais $\mathbf{u}_{r}$ jie neturi viršyti maksimalių ir minimalių poslinkių ribų $\boldsymbol{u}_{\max }$ ir $\boldsymbol{u}_{\min }$. Optimalus uždavinio sprendinys yra $\boldsymbol{F}_{\text {sup }}^{*}, \boldsymbol{F}_{\text {inf }}^{*}, \lambda^{*}$. Patikri- 
namojo optimizavimo uždavinio sprendimo algoritmas, apjungiantis Treską prie Mizeso takumo salygas parodytas 5.2 paveiksle.

1. Sprendžiamas apkrovos optimizavimo uždavinys (5.39)-(5.44). (Treska plastiškumo salygos)

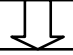

2. Randamas uždavinio (5.39)-(5.44) optimalus sprendinys $\boldsymbol{F}_{\text {sup }}^{*}, \boldsymbol{F}_{\text {inf }}^{*}, \lambda^{*}$.

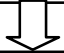

3. Optimalus uždavinio (5.39)-(5.44) sprendinys tampa pradiniu tašku Mizeso sąlygų naudojimui

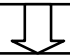

4. Sprendžiamas apkrovos optimizavimo uždavinys (5.45)-(5.50) (Mizeso plastiškumo sąlyga)

5.2 pav. Patikrinamojo uždavinio (Treska-Mizeso) principinė algoritmo schema

Fig. 5.2. The algorithm of check optimization with Tresca and Mises plasticity conditions

Pasinaudojus infliuentinemis matricomis $\boldsymbol{G}$ ir $\boldsymbol{H}$, sudaromas apkrovos optimizavimo uždavinio matematinis modelis Mizeso plastiškumo sąlygų atveju: rasti

$$
\max \left(\mathbf{T}_{\text {sup }}^{T} \mathbf{F}_{\text {sup }}+\mathbf{T}_{\text {inf }}^{T} \mathbf{F}_{\text {inf }}\right),
$$

kai

$$
\begin{gathered}
\varphi_{i j}=\left(M_{0 i}\right)^{2}-\left(\boldsymbol{M}_{e i, j}+\boldsymbol{G} \lambda\right)^{T} \boldsymbol{\Pi}_{i}\left(\boldsymbol{M}_{e i, j}+\boldsymbol{G} \lambda\right) \geq 0, \\
\left.\lambda_{i j} \mid\left(M_{0 i}\right)^{2}-\left(\boldsymbol{M}_{e i, j}+\boldsymbol{G} \lambda\right)^{T} \boldsymbol{\Pi}_{i}\left(\boldsymbol{M}_{e i, j}+\boldsymbol{G} \boldsymbol{\lambda}\right)\right]=0, \\
\lambda_{i j}>0, \boldsymbol{\lambda}=\left(\boldsymbol{\lambda}_{i j}\right), \quad i \in I, j \in J, \\
\boldsymbol{u}_{\text {min }} \leq \boldsymbol{H} \boldsymbol{\lambda}+\boldsymbol{u}_{e, \text { inf }}, \\
\boldsymbol{H} \boldsymbol{\lambda}+\boldsymbol{u}_{e, \text { sup }} \leq \boldsymbol{u}_{\max } .
\end{gathered}
$$


Grafiškai perejjimas nuo Treska prie Mizeso plastiškumo sąlygų parodytas 5.3 paveiksle.

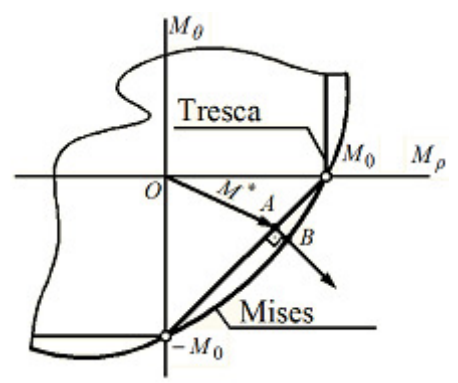

5.3 pav. Perèjimo nuo Treska prie Mizeso takumo sąlygos fragmentas

Fig. 5.3. The fragment of the switch from Tresca plasticity conditions to Mises plasticity conditions

\subsection{Skaitinis pavyzdys}

Nagrinèjama žiedinė su apvalia skyle viduryje paremta išoriniu kontūru lankstine nepaslankia atrama plokšte, kurios geometrija ir kraštinès sąlygos parodytos 5.4 paveiksle. Plokštès spindulys $R=1,0 \mathrm{~m}$, aukštis $h=0,025 \mathrm{~m}$ ir skylès diametras $d=0,3 \mathrm{~m}$. Išorinis kontūras apkrautas išskirstytu pastoviu momentu $F=5,0 \frac{\mathrm{KNm}}{\mathrm{m}^{\prime}}$ (nuolatinè apkrova). Medžiaga - plienas, jo tamprumo modulis $E=210 e^{9} \mathrm{MPa}$, puasono koeficientas $v=0,3$ ir takumo riba $\sigma_{y}=235 e^{6} \mathrm{MPa}$. plokštès ribinis momentas $M_{0}=\frac{1}{4} \sigma_{y} t^{2}=36718,75 \mathrm{Nm}^{\prime}$. Diskretinis modelis parodytas 5.5 paveiksle. Ji atitinka iražų vektorius $\boldsymbol{M}=\left(M_{\rho, 1}, M_{\theta, 1}, M_{\rho, 2}, M_{\theta, 2}, \ldots, M_{\rho, 12}, M_{\theta, 12}\right)^{T}$. Ribojamas pirmojo mazgo vertikalus poslinkis: $0 \leq u_{1} \leq 0,037 \mathrm{~m}$.

Apkrovos optimizavimo uždavinys sprendžiamas pagal 5.2 paveiksle parodytą algoritmą: t. y. pirmiausia sprendžiama pagal matematini modelị (5.39)(5.44), po sprendžiama jau pagal (5.39)-(5.44). Optimizavimo uždavinių nežinomieji yra tolygiai išskirstytos apkrovos q (pav. 5.4) kitimo ribos $\boldsymbol{F}_{\text {sup }}^{*}, \boldsymbol{F}_{\text {inf }}^{*}$ bei plastiniai daugikliai $\lambda^{*}$. Išsprendus uždavini (5.39)-(5.44) su Treska takumo 
sąlygomis gauta $\boldsymbol{F}_{\text {sup }}^{*}=q^{*}=131,246 \mathrm{kPa}$ ir perejus prie Mizeso $\boldsymbol{F}_{\text {sup }}^{*}=q^{*}=140,747$. Suminiai momentai Treska ir Mizeso takumo sąlygu atvejams parodyti paveiksle 5.6.

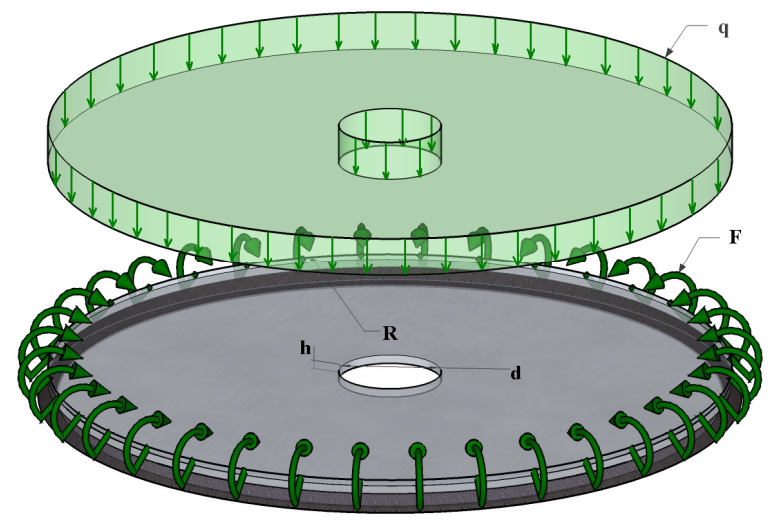

5.4 pav. Apvalios plokštės geometrija ir kraštinès sąlygos

Fig. 5.4. Geometry of round plate and boundary conditions

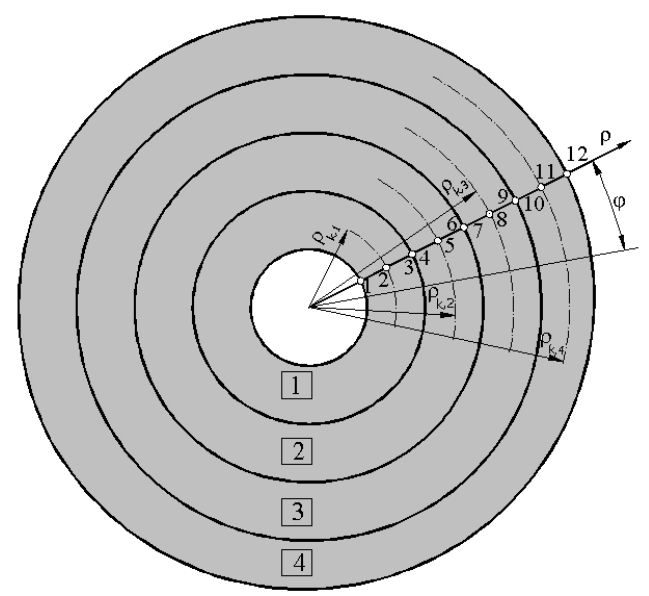

5.5 pav. Apvalios plokštès diskretinis modelis

Fig. 5.5. Discretizaton of round plate 


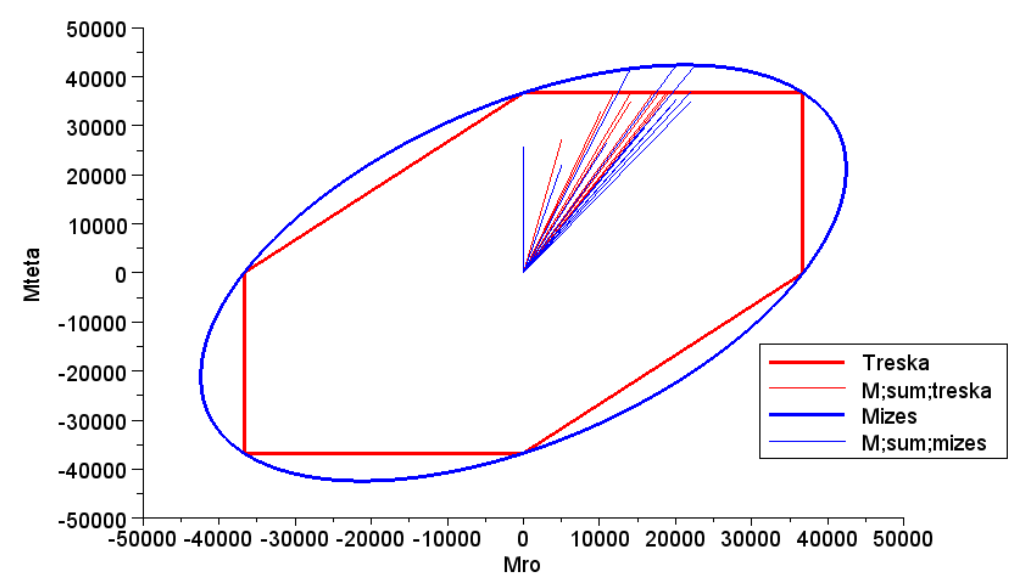

5.6 pav. Suminiai momentai

Fig. 5.6. Total moments

Kaip matome pagal paveikslą 5.6 Mizeso takumo sąlygos leidžia didesnius plastinius momentus, kas sąlygoja ir didesnę tikslo funkcijos reikšmę.

\subsection{Penktojo skyriaus išvados}

1. Treska plastiškumo sąlygų atveju liekamujjų irąžų ir poslinkių infliuentinès matricos nepriklauso nuo liekamuju irą̌ž $\boldsymbol{M}_{r}$.

2. Mizeso plastiškumo sąlygų atveju infliuentinès matricos turètų būti formuojamos, pasitelkus plastiškumo salygu gradientus, kurie jau priklauso nuo $\boldsymbol{M}_{r}$. Pagrindinis patikrinamasis uždavinys Mizeso sąlygu atveju tampa praktiškai sunkiai realizuojamas, net pasitelkus kompiuterines algebros metodus.

3. Vienas iš įmanomų apkrovos optimizavimo uždavinio sprendimo būdụ, taikant Mizeso plastiškumo sąlyga, yra įmanomas tik pasiekus analogiško uždavinio optimalų sprendini, gauta su Treska plastiškumo sąlygomis. 



\section{Bendrosios išvados}

Bet kurios naujos konstrukcijų skaičiavimo metodikos įdiegimo procese (tai galima pavadinti ir eksperimentine pletra) išskirtini trys etapai: 1) algoritmų realizavimas kompiuterinėmis technologijomis 2) metodikos aprūpinimas normatyvine dokumentacija 3) eksperimentinis projektavimas. Nors teoriniai statybinès mechanikos optimizavimo uždaviniai, kuriems skirtas šis disertacinis darbas, yra ¿žanginis konstrukcijų optimalaus projektavimo etapas, vis dèl to ir čia sugebèta praturtinti pirmaji ir antraji etapus susiejant algoritmus bei standartu reikalavimus igyvendinančią programinę įrangą. Visos darbo teorinès išvados ir pasiūlytos metodikos iliustruotos skaitiniais pavyzdžiais. Glaustai aptariamos pagrindinès išvados:

1. Tyrimais nustatyta, kad tamprioji plastinè konstrukcija, veikiama kintamos kartotinès apkrovos, visada prisitaiko, jei analizès netiesinio iškilo matematinio programavimo uždavinys turi nors vieną leistinaji sprendinių srities tašką.

2. Statybinių prisitaikančių konstrukcijų projektavime taikomi apkrovų deriniai, judama ir vienkartè apkrova gali būti realizuojama, pasitelkus kintamos kartotinès apkrovos sampratą.

3. Taikant sukurtuosius optimizavimo uždavinių sprendimo metodus galima priartèti prie statybos inžinerijos praktikai aktualios diskretinès konstrukcijų optimizacijos: nustačius tolygiai kintančius skerspjūvio pa- 
rametrus (sienutès ar lentynos storis, plotas), galima iš gamintojų siūlomų standartinių profiliuočiu sortamento parinkti tokị profili, kurio parametrai yra didesni už apskaičiuotuosius parametrus arba jiems lygūs.

4. Taikant sukurtają iteracinę integralaus projektavimo metodiką galima optimizuoti statybines prisitaikančias konstrukcijas, atsižvelgiant i stiprumo, standumo ir klumpamosios galios (pagal EN1993 ir NEN6771) sąlygas. Necentrinio gniuždymo atveju klumpamosios galios skaičiavime yra atsižvelgiama ir i plastines deformacijas. Taip patobulinus optimizavimo algoritmus, patikslèja plieninių konstrukcijų projektavimo rezultatai.

5. Klumpamosios galios skaičiavimus perkèlus ị komercinę kompiuterinę programą MatrixFrame 4.1 (ar bet kurią kitą programą su idiegtais projektavimo standartais), galima koncentruotis ties paties optimizavimo algoritmo tobulinimu, o ne ties sudetingais necentrinio gniuždymo skaičiavimo algoritmais. Taikant sukurtają iteracinę integralaus projektavimo metodika, galima ivvesti konstrukcijos plastinio būvio kintamuosius i komercinès programos skaičiavimus, t. y. ivertinti kintamą apkrovos pobūdi nenagrinejjant apkrovimo istorijos. Būtent tokios skaičiavimo metodikos yra stokojama komercinèse programose, kuriose dažniausiai yra nagrinejjama tik konkreti apkrovos istorija (tuo būdu imanoma nagrinèti ir ne vieną apkrovimo istorija, po to apskaičiuojant suminę poveikiu gaubtinę). Tačiau atskiru apkrovimo istoriju poveikių suma nėra tapati kintamos kartotinès apkrovos poveikiui, nes konstrukcijoje nuo vienos apkrovimo istorijos atsiradę plastinès sritys (lankstai) itakoja kitos apkrovimo istorijos rezultatus, ir i tai nèra atsižvelgiama. Pasiūlytoji optimizavimo metodika šio trūkumo neturi.

6. Remiantis darbe sukaupta patirtimi, galima teigti, kad optimizavimo uždavinių sprendimo apimtis priklausomai nuo skaičiuojamųų konstrukcijos elementų skaičiaus dideja tiesiškai, o priklausomai nuo apkrovų viršūnių skaičiaus $p=2^{m}$ - eksponentiškai. Atsižvelgus i dabartines asmeninių kompiuteriu galimybes, i̇manoma optimizuoti prisitaikančias konstrukcijas, veikiamas iki 32 apkrovų derinių $(m=4)$. 


\section{Literatūra ir šaltiniai}

Ahuja, R. K; Magnanti, T. L; Orlin, J. B. 1993. Network Flows: Theory, Algorithms, and Applications.

Alwis, W. A. M.; Grundy, P. 1985. Shakedown analysis of plates, International Journal of Mechanical Sciences 27: 71-82.

Atkočiūnas, J. 1994. Design of elastoplastic systems under repeated loading. Vilnius: Science and encyclopaedic publishing house, (in Russian).

Atkočiūnas, J.; Borkowski, A.; König, J. A. 1981. Improved bounds for displacements at shakedown, Computer Methods in Applied Mechanics and Engineering 28: 365-376.

Atkočiūnas, J.; Čižas, A. E. 2009. Netampri乇 konstrukciju mechanika. Technika.

Atkočiūnas, J.; Karkauskas, R. 2010. Tampriu plastiniu strypiniu konstrukciju optimizavimas. Technika.

Atkočiūnas, J.; Nagevičius, J. 2004. Tamprumo teorijos pagrindai. Technika.

Atkočiūnas, J. 1999. Mathematical models of optimization problems at shakedown, Mechanics Research Communications 26: 319-326.

Barauskas, R.; Belevičius, R.; Kačianauskas, R. 2004. Baigtiniu elementu metodo pagrindai. Technika.

Bathe, K. J. 2006. Finite element procedures. Prentice Hall, Pearson Education, Inc.

Bazaraa, M. S.; Sherali H. D.; Shetty, C. M. 2004. Nonlinear programming: theory and algorithms. New York: John Wiley \& Sons Ltd. 
Belytschko, T. 1972. Plane stress shakedown analysis by finite elements, International Journal of Mechanical Sciences 14: 619-625.

Belytschko, T.; Liu, W. K.; Moran, B. 2000. Nonlinear finite elements for continua and structures. New York: John Wiley \& Sons Ltd.

Bertsekas, D. P. 1995. Nonlinear Programming. Athena Scientific

Borkowski, A.; Atkočiūnas, J. 1975. Optimal design for cyclic loading, in A. Sawczuk, Z. Mróz (eds.). Optimization in structural design. Berlin: Springer-Verlag, 433-440.

Bower, A. F. 2010. Applied Mechanics of Solid. CRC Press.

Capurso M., Corradi L., Maier G.: Bounds on deformations and displacements in shakedown theory. Proc. Materiaux et Structures sous Chargement Cyclique, Palaiseau, France. 1978. p. 213-244.

Casciaro, R.; Garcea, G. 2002. An iterative method for shakedown analysis, Computer Methods in Applied Mechanics and Engineering 191: 5761-5792.

Cinquini, C.; Guerlement, G.; Lamblin, D. 1980. Finite element iterative methods for optimal elastic design of circular plates, Computers and Structures 12: 85-92.

Čižas, A. 1993. Medžiagu atsparumas. Technika.

Cohn, M. Z.; Parimi, S. R. 1973. Optimal shakedown of plastic structures for fixed and shakedown loadings, Journal of Applied Mechanics 40: 595-599.

Corradi, L.; Maier, G. 1974. Dynamic inadaptation for elastic-perfectly plastic continua, Journal of Mechanics Physics and Solids 22: 401-413.

Corradi, L.; Zavelani, A. 1974. A linear programming approach to shakedown analysis of structures, Computer Methods in Applied Mechanics and Engineering 3: 37-53.

Čyras, A. 1983. Mathematical models for the analysis and optimization of elastoplastic structures. New York: John Wiley \& Sons Ltd.

Čyras, A. 1989. Statybine mechanika. Mokslas.

Čyras, A.; Atkočiūnas, J. 1984. Mathematical model for the analysis of elastic-plastic structures under repeated-variable loading. Mechanics Research Communications 11: 353-360.

Čyras, A.; Borkowski, A.; Karkauskas, R. 2004. Theory and methods of optimization of rigid-plastic systems. Technika.

De Saxcé G. Sur quelques problèmes de mécanique des solides considérés comme matériaux à potentiels convexes. These de Doctorat, l'Université de Liège. 1986.

Dorosz, St. 1978. An improved bound to maximum deflections of elastic-plastic structures at shakedown, Journal of Structural Mechanics 6: 267-287.

Eurocode 3: Design of steel structures - Part 1-1: General rules and rules for buildings. Brussels, $2005.91 \mathrm{p}$.

Faccioli, E.; Vitiello, E. 1973. A finite element linear programming method for the limit analysis of thin plates, International Journal for Numerical Methods in Engineering 5: 311-325. 
Ferris, M. C.; Tin-Loi, F. 1999. On the solution of a minimum weight elastoplastic problem involving displacement and complimentarity constraints, Computer Methods in Applied Mechanics and Engineering 174: 107-120.

Gallager, R. H. 1975. Finite element analysis. Fundamentals. Englewood Clifts: Prentice-Hall Inc.

Giambanco, F. 2000. Multicriteria optimal design of circular plates, in IASS-IACM 2000, Fourth International Colloquium on Computation of Shell \& Spatial Structures, Chania-Crete, June 4-7, 2000.

Giambanco, F.; Palizzolo, L. 1995. Optimality conditions for shakedown design of trusses, Computational Mechanics 16: 369-378.

Giambanco, F.; Palizzolo, L.; Cirone, L. 1998a. Elastic plastic analysis iterative solution, Computational Mechanics 21: 149-160.

Giambanco, F.; Palizzolo, L.; Cirone, L. 1998b. Computational methods for optimal shakedown design of FE structures, Structural Optimization 15: 284-295.

Giambanco, F.; Palizzolo, L.; Polizzotto, C. 1994a. Optimal shakedown design of beam structures, Structural Optimization 8: 156-167.

Giambanco, F.; Palizzolo, L.; Polizzotto, C. 1994b. Optimal shakedown design of circular plates, ASCE Journal of the Engineering Mechanics Division 120: 2535-2355.

Heyman, J. 1958. Minimum weight of frames under shakedown loading, ASCE Journal of the Engineering Mechanics Division 84: 1-25.

Jankovski, V.; Atkočiūnas, J. 2008. MATLAB implementation in direct probability design of optimal steel trusses, Mechanika 74(6): 30-37.

Jirasek, M.; Bažant, Z. P. 2002. Inelastic analysis of structures. New York: John Wiley\&Sons.

Kalanta, S. 1995. Равновесные конечные элементы в расчётах упругих конструкций [The equilibrium finite elements in computation of elastic structures], Statyba [Civil Engineering] 1: 25-47.

Kalanta, S. 2007. Taikomosios optimizacijos pagrindai. Technika.

Kaliszky, S. 1989. Plasticity: theory and engineering applications. Amsterdam: Elsevier.

Kaliszky, S. 1996. Elasto-plastic analysis with limited plastic deformations and displacements, Journal of Mechanics of Structures and Machines 24: 39-50.

Kaliszky, S.; Lógó, J. 1997. Optimal plastic limit and shakedown design of bar structures with constraints on plastic deformation, Engineering Structures 19: 19-27.

Kaliszky, S.; Lógó, J. 2002. Plastic behaviour and stability constraints in the shakedown analysis and optimal design of trusses, Structural and Multidisciplinary Optimization 24: 118-124.

Kamenjarzh, J.; Merzljakov, A. 1994a. On kinematic method in shakedown theory. I: Duality of extremum problems, International Journal of Plasticity 10: 363-380.

Kamenjarzh, J.; Merzljakov, A. 1994b. On kinematic method in shakedown theory. II: modified kinematic method, International Journal of Plasticity 10: 381-392. 
Kamenjarzh, J.; Weichert, D. 1992. On kinematic upper bounds for the safety factor in shakedown theory, International Journal of Plasticity 8: 827-837.

Kaneko, I.; Maier, G. 1981. Optimum design of plastic structures under displacement's constraints, Computer Methods in Applied Mechanics and Engineering 27: 369-391.

Karadeniz, S.; Ponter, A. R. S. 1984. A linear programming upper bound approach to the shakedown limit of thin shells subjected to variable thermal loading, Journal of strain analysis for engineering design 19: 221-230.

Karkauskas, R.; Krutinis, A.; Atkočiūnas, J.; Kalanta, S.; Nagevičius, J. 1995. Statybinès mechanikos uždaviniu sprendimas kompiuteriais. Mokslo ir enciklopedijų leidykla. $264 \mathrm{p}$.

Kleiber, M.; König, J. A. (eds.). 1990. Inelastic solids and structures. Antoni Sawczuk memorial volume. Swansea: Pineridge Press.

Kleiber, M.; Wozniak, Cz. 1991. Nonlinear mechanics of structures. Warszawa: PWNPolish Scientific Publishers.

Koiter, W. T. 1956. A new general theorem on shakedown of elastic-plastic structures, Proceedings of the Koninklijke Nederlandse Academie van Wetenschappen. Series B. 59: 24-34.

Koiter, W. T. 1960. General theorems for elastic-plastic solids, in I. N. Sneddon, R. Hill (eds.). Progress in solid mechanics. Amsterdam, 165-221. (nèra leidyklos pavadinimo)

König, J. A. 1975. On optimum shakedown design, in A. Sawczuk, Z. Mróz (eds.). Optimization in structural design. Berlin: Springer-Verlag, 402-414.

König, J. A. 1982a. On some developments in the shakedown theory, Advances in Mechanics 5: 237-258.

König, J. A. 1987. Shakedown of elastic-plastic structures. Amsterdam: Elsevier.

König, J. A.; Maier, G. 1981. Shakedown analysis of elastoplastic structures: A review of recent developments, Nuclear Engineering and Design 66: 81-95.

Lanczos, C. 1970. The variational principles of mechanics. Dover publications, Inc.

Lange-Hansen, P. 1998. Comparative study of upper bound methods for the calculation of residual deformations after shakedown. Series R, 49, Lyngby, Technical University of Denmark, Dept. of Structural Engineering and Materials.

Maier, G. 1969. Shakedown theory in perfect elastoplasticity with associated and non-associated flow-laws, Meccanica 6: 250-260.

Maier, G. 1970. A matrix structural theory of piece wise-linear plasticity with interacting yield planes, Meccanica 7: 51-66.

Maier, G.; Zavelani, A.; Benedetti, D. 1972. A finite element approach to optimal design of plastic structures in plane stress, International Journal for Numerical Methods in Engineering 4: 455-473.

Malvern, L. E. 1969. Introduction to the Mechanics of a Continuous Medium. PrenticeHall, Inc.

Melan E. Theorie statisch unbestimmter Systeme. Proceedings Second Congress IABSE, Berlin, 1936. p. 43-64. 
Melan, E. 1938. Der Spannungszustand eines "Mises-Hencky'schen“ Kontinuums bei veränderlicher Belastung, Sitzungsberichte der Akademie der Wissenschaften Wien 147: 73-87.

Melan, E. 1938. Zur Plastizität des räumlichen Kontinuums, Ingenieur-Archiv 9: 116126.

Merkevičiūte, D., Atkočiūnas, J. 2006. Optimal shakedown design of metal structures under stiffness and stability constraints. Journal of Constructional Steel Research. 62: $1270-1275$.

Morelle, P. 1986. Numerical shakedown analysis of axisymmetric sandwich shells. An upper bound formulation, International Journal for Numerical Methods in Engineering 23: 2071-2088.

Morelle, P., 1989. Analyse duale de l'adaptation plastique des structures par la méthode des éléments finis et la programmation mathématique. Thèse de Doctorat, Universitéde Liège, Belgique.

Mróz, Z.; Weichert, D.; Dorosz St. (eds.). 1995. Inelastic behaviour of structures under variable loads. Dordrecht: Kluwer Academic Publishers.

Muscat, M.; Mackenzie, D.; Hamilton, R. 2003. Evaluating shakedown under proportional loading by non-linear static analysis, Computers and Structures 81: 1727-1737.

NEN 6771: Technische Grondslagen voor Bouwconstructies. TGB 1990. Staalconstructies. Stabiliteit, $2000+$ A1, 2001.

Nguyen-Dang H., Morelle P. Numerical shakedown analysis of plates and shells of revolution. In: Proceedings of $3^{\text {rd }}$ world congress and exhibition on FEMs. Beverly Hills. 1981.

Nguyen-Dang, H.; Morelle, P. 1990. Optimal plastic design and the development of practical software. In: D. Lloyd Smith (Ed.). Mathematical programming methods in structural plasticity. Springer-Verlag, Berlin. 1990. p. 207-229.

Palizzolo, L. 2000. Multicriteria optimal design of continuous beams, in ECCOMAS 2000, European Congress on Computational Methods in Applied Sciences and Engineering, Barcelona, September 11-14, 2000.

Pham, D. C. 2003. Plastic collapse of a circular plate under cyclic loads, International Journal of Plasticity 19: 547-559.

Polizzotto, C. 1982. A unified treatment of shakedown theory and related bounding techniques, Solid Mechanics Archives 7: 19-75.

Polizzotto, C. 1984. Shakedown analysis and design in presence of limited ductility behaviour, Engineering Structures 6: 80-86.

Polizzotto, C. 1993b. A study on plastic shakedown of structures. Part II: Theorems, Journal of Applied Mechanics 60: 324-330.

Polizzotto, C. 2003. Variational methods for the steady state response of elastic-plastic solids subjected to cyclic loads, International Journal of Solids and Structures 40: 26732697. 
Polizzotto, C.; Rizzo, S. 1987. Optimum design of reinforced concrete under variable loadings, Engineering Optimization 11: 327-338.

Ponter, A. R. S. 1972. An upper bound on the small displacements of elastic, perfectly plastic structures, ASME Transactions Series E Journal of Applied Mechanics 39: 959-963.

Ponter, A. R. S. 1975. General displacement and work bounds for dynamically loaded bodies, Journal Mechanic Physic and Solids 23: 151-163.

Ponter, A. R. S.; Engelhardt, M. 2000. Shakedown limits for a general yield condition: implementation and application for a von Mises yield condition, in D. Weichert, G. Maier (eds.). Inealstic Analysis of Structures under Variable Loads. Dordrecht: Kluwer Academic Publishers, 11-29.

Ponter, A. R. S.; Fuschi, P.; Engelhardt, M. 2000. Limit analysis for a general class of yield conditions, European Journal of Mechanics - A/Solids 19: 401-421.

Ponter, A. R. S.; Karadeniz, S.; Carter, K. F. 1990. Extended upper bound shakedown theory and finite element method for axisymmetric thin shells, in M. Kleiber and J.A.Konig (eds.). Inelastic Solids and Structures. Swansea: Pineridge Press, Swansea, $421-428$.

Pycko, S. 1997. A cycle-oriented incremental analysis of shakedown problems, International Journal for Numerical Methods in Engineering 40: 3163-3179.

Rizzo, S. 1983. Shakedown analysis of discrete elastic-work-hardening structures with displacement constraints, in Proceedings International Conference on Structural Mechanics in Reactor Technology, SMIRT-7. Chicago, 311-318.

Rizzo, S.; Giambanco, F. 1984. Shakedown analysis of limited-ductility structures, Meccanica 19: 151-157.

Rozvany, G. I. N. 1976. Optimal design of flexural systems: Beams, grillages, slabs, plates, and shells. New York: Pergamon Press.

Rozvany, G. I. N. 1989. Structural design via optimally criteria. Dordrecht: Kluwer Academia Publishers.

Save, M. A.; Prager, W. 1985. Structural optimization. New York: Plenum Press.

Smith, I. M.; Griffiths, D. V. 2004. Programming the finite element method. John Willey \& Sons, Ltd.

Spiliopoulos, K. V. 1999. A fully automatic force method for the optimal shakedown design of frames, Computational Mechanics 23: 299-307.

Tin-Loi, F. 2000. Optimum shakedown design under residual displacement constraints, Structural and Multidisciplinary Optimization 19: 130-139.

Vitiello, E. 1972. Upper bounds to plastic strains in shakedown of structures subjected to cyclic loads, Meccanica 1: 205-213.

Vu, D. K.; Yan, A. M.; Nguyen-Dang, H. 2004a. A dual form for discretized kinematic formulation in shakedown analysis, International Journal of Solids and Structures 41: 267-277. 
Vu, D. K.; Yan. A. M.; Nguyen-Dang, H. 2004b. A primal-dual algorithm for shakedown analysis of structures, Computer Methods in Applied Mechanics and Engineering 193: 4663-4674.

Weichert, D.; Maier, G. (eds.). 2000. Inealstic analysis of structures under variable loads. Theory and enginering applications. Dordrecht: Kluwer Academic Publishers.

Weichert, D.; Maier, G. (eds.). 2002. Inelastic behaviour of structures under variable repeated loads. Wien: Springer-Verlag.

Žiliukas, A. 2004. Medžiagu mechanika. Technologija.

Zouain, N.; Borges, L.; Silveira, J. L. 2002. An algorithm for shakedown analysis with nonlinear yield functions, Computer Methods in Applied Mechanics and Engineering 191: 2463-2481.

Zouain, N.; Silveira, J. L. 2000. Variational principles for shakedown analysis, in D. Weichert, G. Maier (eds.). Inealstic analysis of structures under variable loads. Theory and enginering applications. Dordrecht: Kluwer Academic Publishers, 147-165.

Zouain, N.; Silveira, J. L. 1999. Extremum principles for bounds to shakedown loads, European Journal of Mechanics - A/Solids 18: 879-901.

Храптович, Э. В.; Аткочюнас, Ю. Ю. 2001. Особенности применения математического программирования в задачах приспособляемости конструкций. Statyba 2I: 106-114. 



\section{Autoriaus publikaciju disertacijos tema sąrašas}

\section{Straipsniai recenzuojamuose mokslo žurnaluose}

Atkočiūnas, J.; Merkevičiūtè, D.; Venskus, A.; Nagevičius, J. 2007a. Prisitaikančiujuc santvarų optimizavimo uždavinių matematiniai modeliai judamosios apkrovos atveju. Ükio technologinis ir ekonominis vystymas. 2(13): 93-99. ISSN 1392-8619. (Thomson ISI Web of Science)

Atkočiūnas, J.; Merkevičiūtė, D.; Venskus, A.; Skaržauskas, V. 2007b. Nonlinear programming and optimal shakedown design of frames. Mechanika. 2(64): 27-33. ISSN 1392-1207. (Thomson ISI Web of Science)

Atkočiūnas, J.; Merkevičiūtè, D.; Venskus. A. 2008a. Optimal shakedown design of bar systems: Strength, stiffness and stability constraints. Computers and Structures. 1718(86): 1757-1768. ISSN 0045-7949. (Thomson ISI Web of Science)

Atkočiūnas, J.; Venskus. A. 2011. Optimal shakedown design of frames under stability conditions accordin to standards. Computers and Structures. 3-4(89): 435-443. ISSN 0045-7949. (Thomson ISI Web of Science)

Kalanta, S.; Atkočiūnas, J.; Venskus, A. 2009. Discrete optimization problems of the steel bar structures. Engineering Structures. 6(31): 1298-1304. ISSN 0141-0296. (Thomson ISI Web of Science) 
Venskus, A.; Atkočiūnas, J.; Kalanta, S.; Ulitinas, T. 2010. Integrated load optimization of elastic-plastic axisymmetric plates at shakedown. Journal of Civil Engineering and Management. 2(16): 203-208. ISSN 1392-3730. (Thomson ISI Web of Science)

\section{Straipsniai kituose leidiniuose}

Atkočiūnas, J.; Merkevičiūtė, D.; Venskus, A.; Rimkus, L. 2007c. Optimal shakedown design of steel structures. Anwendung der Optimierung in der nichtlinearen Tragwerksanalyse. Schriftenreihe des Institutes fuer Konstruktiven Ingenieurbau BauhausUniversität Weimar. Weimar : Bauhaus-Universität Weimar, Fakultät Bauingenieurwesen, 137-144. ISBN 978-3-86068-307-1.

Atkočiūnas, J.; Venskus, A. 2008b . Optimal shakedown design of frames under stability conditions, Proceedings of the Ninth International Conference on Computational Structures Technology. Stirlingshire: Civil-Comp Press, 1-12. ISBN 978-1905-08-822-5.

Kalanta, S.; Atkočiūnas, J.; Venskus, A. 2007d. Discrete optimization problems of the steel bar structures, selected papers of the 9th international conference "Modern building materials, structures and techniques". Vilnius: Technika, 949-954. ISBN 978-995528-200-6.

Kalanta, S.; Atkočiūnas, J.; Venskus, A. 2007e. Discrete optimization problems of the steel bar structures, in proceedings of the 9th international conference "Modern building materials, structures and techniques", [CD]. Vilnius: Technika, 1-6. ISBN 978-995528-189-4. (ISI Web of Science)

Venskus, A.; Atkočiūnas, J. 2005. Plokštès analizès netiesinio uždavinio sprendimo programa "Rūta" ir jos integracijos galimybės, iš Statyba: 8-osios Lietuvos jaunuju mokslininku konferencijos „Lietuva be mokslo - Lietuva be ateities" medžiaga. Vilnius: Technika, 277-282. ISBN 9986-05-893-7.

Venskus, A.; Atkočiūnas, J. 2006. Patobulintas prisitaikančių sistemų optimizacijos uždavinių sprendimo algoritmas, iš Statyba: 9-osios Lietuvos jaunuju mokslininku konferencijos „Mokslas - Lietuvos ateitis" medžiaga. Vilnius: Technika, 265-270. ISBN 9955-28-047-6. 


\section{Santrauka anglų kalba}

\section{Introduction}

The introductory chapter presents the relevance of the problem as well as the objective and the main goals of investigation, scientific novelty and originality.

\section{Formulation of the problem}

The solution of strength, stiffness and stability problems of structures exposed to repeated variable mechanical or other type loading, is closely linked to shakedown theory. This theory still not used in its full power because of incomplete formulation of some mathematical problems and inconsistent use of the methods of mathematical programming theory.

Solution of shakedown structures optimization problems is difficult as stress-strain state of dissipative systems depends on loading history. Theses difficult optimization problems can be solved by applying energy principles and mathematical programming theory.

The task of the work is to create unified methodology for optimization of elasticplastic shakedown structures with strength, stiffness and stability constraints by applying extremum energy principles, mathematical programming, numerical methods and stateof-the-art computation technologies. 


\section{Topicality of the thesis}

Today the evaluation of stability conditions for optimization problems involving elasticplastic frames remains a topical scientific problem. For example, it is permitted to design elastic-plastic frames using the EN1993 or NEN 6771 standards, but in these standards, the methodology and algorithms for stability evaluation of shakedown structures are not fully described. This situation influenced the choice of topic for this dissertation: optimization methods of shakedown structures in the context of standards. In this research, two types of problems are considered. The first problem is the plastic moments minimization (design problem) of the shakedown frame. The unknowns in this problem are the plastic moments. The second problem is the- load-optimization (checking) problem for a frame subjected to variable repeated load. By solving the load-optimization problem, the maximal load-variation bounds which ensure frame integrity and which satisfy the stiffness and stability requirements of the structure can be found.

\section{Aim and tasks of the work}

The main objectives of the present work are: 1) improve existing optimization mathematical models evaluating strength and stiffness constraints for shakedown structures and create new optimization methodology incorporating stability (eccentric compression) constraints; 2) integrate the created optimization software with commercial software MatrixFrame and solve practical optimization problems of shakedown structures according to standards; 3 ) perform integrated optimization of shakedown structures with strength, stiffness and stability constraints accordingly to standards.

The following tasks have to be performed:

1. Create the improved optimization mathematical models of design and checking problems for shakedown structures including into models elastic and residual displacements.

2. Use the real cross-sections (with no idealisation) for calculations;

3. Create a software for analysis and optimization of shakedown structures.

4. Perform calculations of shakedown structures.

5. Create a methodology allowing to transfer (integrate) plastic state variables (residual forces and displacements) obtained from author created software to MatrixFrame (or similar software) structure analysis flow.

6. Define the relation between the repeated variable load and load combinations occurring in standards.

\section{Scientific novelty}

1. New nonlinear mathematical models of checking and design problems with constraints ensuring shakedown and stiffness with stability of structures are created.

2. The methodology of shakedown bar structures optimization was implemented: improved nonlinear mathematical models considering strength, stiffness and 
stability (EN1993 and NEN6771) constraints, solution algorithms and performed calculations.

3. New optimization methodology integrating authors created software modules with commercial software (MatrixFrame) was created.

4. A new algorithm for the load optimization problem combining von Mises and Tresca yield criterion based on the Rosen project gradient method is proposed.

\section{Methodology of research}

The extremum energy principles of deformable body and theory of mathematical programming are employed in the present work. The equilibrium finite elements were used for discrete mathematical models of optimization problems. The research and calculations are based on small displacements assumption. The investigation is built on author software-engineer sound experience in Matrix Software Company by developing commercial software MatrixFrame for structural analysis and design.

\section{Practical value}

The created new optimization methods and mathematical models for shakedown structures evaluating strength, stiffness and stability constraints can be used for real structure design according to standards. The software for shakedown structures optimization problems was created.

\section{The scope of the scientific work}

The scientific work is presented in Lithuanian language. It consists of five chapters, the first of which is an introduction, and the last one presents the generalization of achieved results and summary, list of literature, list of publication and addenda. The total scope of the dissertation - 94 pages, 27 pictures, 7 tables, 125 numbered formulas and 2 addenda. The list of references comprises 122 items.

\section{Review of Shakedown Theory}

This chapter reviews the principal static (Melan) and kinematic (Koiter) shakedown theorems, the shakedown analysis, the constraint methods, the optimal design of shakedown structures, the duality and mathematical programming and the main traits of stateof-the-art research in this field. After review of literature it is concluded:

1. The real loading of civil engineering structures has cyclic nature; therefore the application of shakedown theory in safety evaluation is important and often necessary requirement.

2. The residual displacements part evaluated in mathematical models of optimization problems usually calculated by well-known Koiter inequality. It is necessary to invoke for calculations the residual displacement matrix.

3. The cyclic loading in the commercial software usually is evaluated by loading history. Unfortunately it is not enough to satisfy shakedown of structures. 
4. Obviously that existing methodology lack connection between shakedown theory and real design based on standards.

5. There is no methodology to evaluate loading in optimal shakedown design calculations through load combinations.

6. The synthesis of methodology for shakedown structures optimization and real design is not fully elaborated.

\section{Improved Optimization Models for Shakedown Structures}

The discrete model of the frame at shakedown consists of $s$ equilibrium finite elements. The limit force $S_{0 k}(k=1,2, \ldots, s)$ is assumed constant in the whole finite element. The $k$ th element has $s_{k}$ nodal points. The approximated nodal forces of each element are the bending moments $M$ and axial forces $N$. Generalised nodal force $\boldsymbol{S}_{v}=\left(M_{l}, N_{l}\right)^{T}, l=1,2, \ldots, s_{k}, v=1,2, \ldots, \zeta$, where $\zeta$ is the total number of discrete model design sections. The nodal internal forces of each element are a combination of one vector of length $n$ of discrete model forces, $\boldsymbol{S}=\left(\boldsymbol{S}_{1}, \boldsymbol{S}_{2}, \ldots, \boldsymbol{S}_{v}, \ldots, \boldsymbol{S}_{\zeta}\right)^{T}=\left(S_{z}\right)^{T}$, and one vector of length $n, \boldsymbol{\Theta}=\left(\boldsymbol{\Theta}_{1}, \boldsymbol{\Theta}_{2}, \ldots, \boldsymbol{\Theta}_{v}, \ldots, \boldsymbol{\Theta}_{\zeta}\right)^{T}=\left(\Theta_{z}\right)^{T}, z=1,2, \ldots, n$. The degrees of freedom are $m$, corresponding to $m$ displacement vectors $\boldsymbol{u}_{e}=\left(u_{e, 1}, u_{e, 2}, \ldots, u_{e, m}\right)^{T}$. The load $\boldsymbol{F}(t)$ is characterized by time $t$ and the independent variation bounds, $\boldsymbol{F}_{\text {sup }}=\left(F_{1, \text { sup }}, F_{2, \text { sup }}, \ldots, F_{m, \text { sup }}\right)^{T} \quad$ and $\quad \boldsymbol{F}_{\text {inf }}=\left(F_{1, \text { inf }}, F_{2, \text { inf }}, \ldots, F_{m, \text { inf }}\right)^{T}$, $\left(\boldsymbol{F}_{\text {inf }} \leq \boldsymbol{F}(t) \leq \boldsymbol{F}_{\text {sup }}\right)$. The elastic displacements $\boldsymbol{u}_{e}(t)$ and the forces $\boldsymbol{S}_{e}(t)$ of the structure are determined using influence matrices of displacements and forces, $\boldsymbol{\beta}=\left(\boldsymbol{A} \boldsymbol{K} \boldsymbol{A}^{T}\right)^{-1}, \quad \boldsymbol{\alpha}=\boldsymbol{K} \boldsymbol{A}^{T} \boldsymbol{\beta} \quad$ respectively, where $\boldsymbol{u}_{e}(t)=\boldsymbol{\beta} \boldsymbol{F}(t), \quad \boldsymbol{S}_{e}(t)=\boldsymbol{\alpha} \boldsymbol{F}(t)$, $\boldsymbol{K}=\boldsymbol{D}^{-1}$. Here $\boldsymbol{A}$ is a coefficient matrix of equilibrium equations, $\boldsymbol{A} \boldsymbol{S}=\boldsymbol{F}$, and $\boldsymbol{D}$ is a quasi-diagonal flexibility matrix. The residual displacements $\boldsymbol{u}_{r}$ and the forces $\boldsymbol{S}_{r}$ are related to the vector of plasticity multipliers $\lambda$ by the influence matrices $\boldsymbol{H}$ and $\boldsymbol{G}$, where $\boldsymbol{u}_{r}=\overline{\boldsymbol{H}} \boldsymbol{\Phi}^{T} \boldsymbol{\lambda}=\boldsymbol{H} \boldsymbol{\lambda}, \boldsymbol{S}_{r}=\overline{\boldsymbol{G}} \boldsymbol{\Phi}^{T} \boldsymbol{\lambda}=\boldsymbol{G} \boldsymbol{\lambda}, \overline{\boldsymbol{H}}=\boldsymbol{\alpha}^{T}$, and $\overline{\boldsymbol{G}}=\boldsymbol{\alpha} \boldsymbol{A} \boldsymbol{K}-\boldsymbol{K}$. Here $\boldsymbol{\Phi}$ is the matrix of piecewise-linearized yield conditions, $\varphi_{j}$. The number of all possible combinations $\boldsymbol{F}_{j}$ of load bounds $\boldsymbol{F}_{\text {sup }}, \boldsymbol{F}_{\text {inf }}$ is $p=2^{m}\left(\boldsymbol{F}_{\text {inf }} \leq \boldsymbol{F}_{j} \leq \boldsymbol{F}_{\text {sup }}\right)$, where $\boldsymbol{S}_{e j}=\boldsymbol{\alpha} \boldsymbol{F}_{j}, \boldsymbol{u}_{e j}=\boldsymbol{\beta} \boldsymbol{F}_{j}, j=1,2, \ldots, p$. It is possible to evaluate directly, not only the variable repeated load $\boldsymbol{F}_{j}$, but also other loads $\boldsymbol{F}_{c}$ (for example a persistent load), addi- 
tionally including them in combination $j$. The elastic forces $\boldsymbol{S}_{e c}$ and elastic displacements $\boldsymbol{u}_{e c}$ resulting from the loads $\boldsymbol{F}_{c}$ are calculated as $\boldsymbol{S}_{e c}=\boldsymbol{\alpha} \boldsymbol{F}_{c}, \boldsymbol{u}_{e c}=\boldsymbol{\beta} \boldsymbol{F}_{c}$.

The general mathematical models presented in Table S1 are the basis for the development of the mathematical optimization models of frames at shakedown which are considered in dissertation. In both design and check problems, the objective functions are described by equations (1) and (6) respectively, where the vectors $\boldsymbol{L}, \boldsymbol{T}_{\text {sup }}$, and $\boldsymbol{T}_{\text {inf }}$ contain weighting coefficients. The yield conditions $\varphi_{j}(j=1,2, \ldots, p)$ are given by equations (2) and (7) respectively, where $j$ is the number of all possible combinations $\boldsymbol{F}_{j}$ of load bounds $\boldsymbol{F}_{\text {sup }}, \boldsymbol{F}_{\text {inf }}$. The complementary slackness conditions of mathematical programming are given by equations (3) and (8) respectively. Equations (4) and (9) are the respective constraints for the problem unknowns. The vectors $\boldsymbol{M}_{\max }, \boldsymbol{M}_{\min }$, $\boldsymbol{F}_{\text {max }}$, and $\boldsymbol{F}_{\min }$ play a major role in stability evaluation. For further details on this topic, see Section 3. The stiffness constraints are given in equations (5) and (10) respectively. The optimal parameters for frame design using mathematical model (1)-(5) can be calculated when the yield limit $\sigma_{y k}$ of the frame material, the lengths $L_{k}$ of all elements $k(k=1,2, \ldots, s)$, and the load-variation bounds $\boldsymbol{F}_{\text {sup }}, \boldsymbol{F}_{\text {inf }}$ are known.

Table S1. General mathematical models of optimization problems

\begin{tabular}{|c|c|c|}
\hline \multicolumn{2}{|l|}{ Design problem } & Check problem \\
\hline $\begin{array}{l}\text { find } \quad \min \boldsymbol{L}^{T} \boldsymbol{M}_{0} \\
\text { subject to }\end{array}$ & (1) & $\begin{array}{l}\text { find } \max \left(\boldsymbol{T}_{\text {sup }}^{T} \boldsymbol{F}_{\text {sup }}-\boldsymbol{T}_{\text {inf }}^{T} \boldsymbol{F}_{\text {inf }}\right), \text { (6) } \\
\text { subject to }\end{array}$ \\
\hline $\begin{array}{c}\varphi_{j}=\boldsymbol{M}_{0}-\boldsymbol{\Phi}\left(\boldsymbol{G} \boldsymbol{\lambda}+\boldsymbol{S}_{e j}+\boldsymbol{S}_{e c}\right) \geq \mathbf{0}, \\
\lambda_{j}^{T} \boldsymbol{\varphi}_{j}=0,\end{array}$ & (2) & $\begin{array}{c}\boldsymbol{\varphi}_{j}=\boldsymbol{M}_{0}-\boldsymbol{\Phi}\left(\boldsymbol{G} \lambda+\boldsymbol{S}_{e j}+\boldsymbol{S}_{e c}\right) \geq \mathbf{0} \\
\lambda_{j}^{T} \boldsymbol{\varphi}_{j}=0\end{array}$ \\
\hline$\lambda_{j} \geq \mathbf{0}, \lambda=\sum_{j} \lambda_{j}, j=1,2, \ldots, p$ & (3) & $\lambda_{j} \geq \mathbf{0}, \lambda=\sum_{j} \lambda_{j}, j=1,2, \ldots, p$ \\
\hline $\boldsymbol{M}_{\min } \leq \boldsymbol{M}_{0} \leq \boldsymbol{M}_{\max }$ & (4) & $\mathbf{0} \leq \boldsymbol{F}_{\text {sup }} \leq \boldsymbol{F}_{\text {max }}, \boldsymbol{F}_{\text {min }} \leq \boldsymbol{F}_{\text {inf }} \leq \mathbf{0}$ \\
\hline $\boldsymbol{u}_{\min } \leq\left(\boldsymbol{H} \boldsymbol{\lambda}+\boldsymbol{u}_{e j}+\boldsymbol{u}_{e c}\right) \leq \boldsymbol{u}_{\max }$. & (5) & $\boldsymbol{u}_{\min } \leq\left(\boldsymbol{H} \lambda+\boldsymbol{u}_{e j}+\boldsymbol{u}_{e c}\right) \leq \boldsymbol{u}_{\max }$ \\
\hline
\end{tabular}

Depending on the cross-sectional shape, various yield conditions can be assumed. The dissertation focuses on yield conditions for rolled I-beam steel sections.

The relation $c_{k}=\frac{M_{0 k}}{N_{0 k}}, k \in K$ should be determined in advance. The limit moment, $M_{0 k}=\sigma_{y k} W_{p l, k}=\xi\left(\sigma_{y k}, A_{k}\right)$, and the limit axial force, $N_{0 k}=\sigma_{y k} A_{k}$, of the element are functions of the cross-sectional area, $A_{k}$, and the yield limit of the material, 
$\sigma_{y k}$. The limit moments $M_{0 k}$ of the frame elements and the vectors of plasticity multipliers $\lambda_{j} \geq 0, j=1,2, \ldots, p$ are the unknowns of the nonlinear mathematical programming problem (1)-(5). The structural requirements for the frames, $\boldsymbol{M}_{\min }$ and $\boldsymbol{M}_{\max }$, are given by conditions (4). The limit moments $\boldsymbol{M}_{0}$ and the influence matrices $\boldsymbol{\alpha}, \boldsymbol{\beta}, \boldsymbol{G}$, $\boldsymbol{H}$ are related to the $A_{k}, k=1,2, \ldots, s$; these matrices are recalculated during the solution of problem (1)-(5). If the stiffness and stability constraints are neglected, the frame will approach, but not reach, the point of cyclic-plastic collapse. The optimal solution of problem (1)-(5) consists of the vectors $\boldsymbol{M}_{0}^{*}$ and $\lambda_{j}^{*}, j=1,2, \ldots, p$.

In the case of variable repeated load, the problem of determining the load-variation bounds $\boldsymbol{F}_{\text {sup }}, \boldsymbol{F}_{\text {inf }}$ for problem (6)-(10) is also important. This problem can be stated as follows: find the shakedown load-variation bounds $\boldsymbol{F}_{\text {sup }}, \boldsymbol{F}_{\text {inf }}$, which satisfy the prescribed optimality criterion, $\max \left(\boldsymbol{T}_{\text {sup }}^{T} \boldsymbol{F}_{\text {sup }}-\boldsymbol{T}_{\text {inf }}^{T} \boldsymbol{F}_{\text {inf }}\right)$, and also the strength, stiffness, and stability requirements of the structure. The vector of limit bending moments $\boldsymbol{M}_{0}$ and the limits $\boldsymbol{u}_{\min }, \boldsymbol{u}_{\max }$ of the total displacements $\boldsymbol{u}=\boldsymbol{u}_{r}+\boldsymbol{u}_{e j}+\boldsymbol{u}_{e c}$ are known from problem (6)-(10). The optimal solution of this problem consists of the vectors $\boldsymbol{F}_{\text {sup }}^{*}, \boldsymbol{F}_{\text {inf }}^{*}$, and $\lambda_{j}^{*}, j=1,2, \ldots, p$.

A rearrangement of mathematical models (1)-(5) and (6)-(10) for purposes of computer implementation is presented in Table S2.

Table S2. Mathematical models used in the computer implementation

\begin{tabular}{|c|c|}
\hline Design problem & Check problem \\
\hline $\begin{array}{l}\text { find } \min \left(\boldsymbol{L}^{T} \boldsymbol{M}_{0}+\lambda_{j}^{T} \boldsymbol{\varphi}_{j}\right), \text { (11) } \\
\text { subject to }\end{array}$ & $\begin{array}{l}\text { find } \max \left(\boldsymbol{T}_{\text {sup }}^{T} \boldsymbol{F}_{\text {sup }}-\boldsymbol{T}_{\text {inf }}^{T} \boldsymbol{F}_{\text {inf }}-\lambda_{j}^{T} \boldsymbol{\varphi}_{j}\right), \text { (16) } \\
\text { subject to }\end{array}$ \\
\hline $\boldsymbol{\varphi}_{j}=\boldsymbol{M}_{0}-\boldsymbol{\Phi}\left(\boldsymbol{G} \boldsymbol{\lambda}+\boldsymbol{S}_{e j}+\boldsymbol{S}_{e c}\right) \geq \mathbf{0},(12)$ & $\boldsymbol{\varphi}_{j}=\boldsymbol{M}_{0}-\boldsymbol{\Phi}\left(\boldsymbol{G} \lambda+\boldsymbol{S}_{e j}+\boldsymbol{S}_{e c}\right) \geq \mathbf{0}$ \\
\hline$\lambda_{j} \geq \mathbf{0}, \lambda=\sum_{j} \lambda_{j}, j=1,2, \ldots, p$ & $\lambda_{j} \geq \mathbf{0}, \lambda=\sum_{j} \lambda_{j}, j=1,2, \ldots, p$ \\
\hline $\boldsymbol{M}_{\min } \leq \boldsymbol{M}_{0} \leq \boldsymbol{M}_{\max }$ & $\mathbf{0} \leq \boldsymbol{F}_{\text {sup }} \leq \boldsymbol{F}_{\text {max }}, \boldsymbol{F}_{\text {min }} \leq \boldsymbol{F}_{\text {inf }} \leq \mathbf{0}$, \\
\hline $\boldsymbol{u}_{\min } \leq\left(\boldsymbol{H} \boldsymbol{\lambda}+\boldsymbol{u}_{e j}+\boldsymbol{u}_{e c}\right) \leq \boldsymbol{u}_{\max }$ & $\boldsymbol{u}_{\min } \leq\left(\boldsymbol{H} \boldsymbol{\lambda}+\boldsymbol{u}_{e j}+\boldsymbol{u}_{e c}\right) \leq \boldsymbol{u}_{\max }$ \\
\hline
\end{tabular}

In mathematical models (11)-(15) and (16)-(20), the complementary slackness conditions given in equations (3) and (8), $\lambda_{j}^{T} \varphi_{j}=0$, are moved to the objective functions given in equations (11) and (16). This rearrangement is made because the optimal solu- 
tion gives $\lambda_{j}^{T} \boldsymbol{\varphi}_{j}=0$ and because of the Lagrangian relaxation principle, which allows placing constraints into an objective function. If the complementary slackness condition is part of the objective function, the optimization process is considerably faster, because the condition $\lambda_{j}^{T} \varphi_{j}=0$ is satisfied, not during ordinary iteration, but only when the optimal solution is reached.

The following where concluded:

1. The design and check mathematical models of shakedown structures suppose new theoretical statement: structure will shakedown if problems have initial admissible point.

2. Design of plastic structures should be bases on shakedown theory that do not require detailed investigation of loading history.

3. Continues optimization problems can be introductory step for discrete optimization.

\section{Optimization of Shakedown Structures in the Context of Standards}

The load combinations, occurring in engineering practice, can be modelled as separate cases of variable repeated load. For example if the number of all possible combinations $\boldsymbol{F}_{j}$ of load bounds $\boldsymbol{F}_{\text {sup }}, \boldsymbol{F}_{\text {inf }}$ is $p=2^{2}=4$, then the load domain can be described using four load combinations (Table S3, a). The load combinations can be described by introducing additional multipliers, where the values of the multipliers (the coefficients of each load combination) $k_{11}, k_{12}, \ldots, k_{43}$ and the load-variation bounds can be determined by the requirements of the various standards (Table $S 3, b$ ).

Table S3. The load domain and corresponding load combinations

\begin{tabular}{|l|l|l|l|}
\hline & 1) $\boldsymbol{F}_{1, \text { sup }}+\boldsymbol{F}_{2, \text { sup }}+\boldsymbol{F}_{c} ;$ & & 1) $k_{11} \boldsymbol{F}_{1, \text { sup }}+k_{12} \boldsymbol{F}_{2, \text { sup }}+k_{13} \boldsymbol{F}_{c} ;$ \\
a) & 2) $\boldsymbol{F}_{1, \text { sup }}+\boldsymbol{F}_{2, \text { inf }}+\boldsymbol{F}_{c} ;$ \\
& 3) $\boldsymbol{F}_{1, \text { inf }}+\boldsymbol{F}_{2, \text { sup }}+\boldsymbol{F}_{c} ;$ & b) & 2) $k_{21} \boldsymbol{F}_{1, \text { sup }}+k_{22} \boldsymbol{F}_{2, \text { inf }}+k_{23} \boldsymbol{F}_{c} ;$ \\
& 4) $\boldsymbol{F}_{1, \text { inf }}+\boldsymbol{F}_{2, \text { inf }}+\boldsymbol{F}_{c}$ & & 3) $k_{31} \boldsymbol{F}_{1, \text { inf }}+k_{32} \boldsymbol{F}_{2, \text { sup }}+k_{33} \boldsymbol{F}_{c} ;$ \\
& 4) $k_{41} \boldsymbol{F}_{1, \text { inf }}+k_{42} \boldsymbol{F}_{2, \text { inf }}+k_{43} \boldsymbol{F}_{c} ;$
\end{tabular}

For example, if $\boldsymbol{F}_{1}$ represents wind load, $\boldsymbol{F}_{2}$ snow load, and $\boldsymbol{F}_{c}$ permanent load, then the load bounds are: $\boldsymbol{F}_{1, \text { inf }}=$ wind from right (WFR), $\boldsymbol{F}_{1, \text { sup }}=$ wind from left (WFL), $\boldsymbol{F}_{2, \text { inf }}=$ snow from bottom (SFB, included to complete the formal description, but cannot occur in reality), and $\boldsymbol{F}_{2, \text { sup }}=$ snow from top (SFT). In this paper, the distributed wind-load action is replaced by a set of concentrated equivalent loads, 
$\boldsymbol{F}_{1}=\left\{F_{1}^{1}, F_{1}^{2}, F_{1}^{3}, F_{1}^{4}, F_{1}^{5}\right\}$. The numerical values of the load bounds are determined according to the Eurocode 1 standard. According to this standard, the load domain can be expressed as follows:

1) $k_{11} W F L+k_{12} S F T+k_{13} \boldsymbol{F}_{c}$

3) $k_{31} W F R+k_{32} S F T+k_{33} \boldsymbol{F}_{c}$;

2) $k_{21} W F L+k_{22} S F B+k_{23} \boldsymbol{F}_{c}$;

4) $k_{41} W F R+k_{42} S F B+k_{43} \boldsymbol{F}_{c}$.

If external influences are incompatible (for example, snow and wind), then they can be easily excluded from the load combination by setting the corresponding multipliers to zero.

The stability of mathematical models (11)-(15) and (16)-(20) is evaluated using the structural restrictions given by equations (14) and (19) respectively, which are calculated according to the stability requirements of the EN1993 or NEN 6771 standards (or even another standard). Various standards have been implemented in commercial software that is available to meet the needs of designers. The author of this dissertation has used the MatrixFrame building-industry software, version 4.1, for stability evaluation.

Frame plastic moments minimization (11)-(15) and load optimization (16)-(20) problems are performed in an iterative manner (Fig. S1., Fig. S2.).

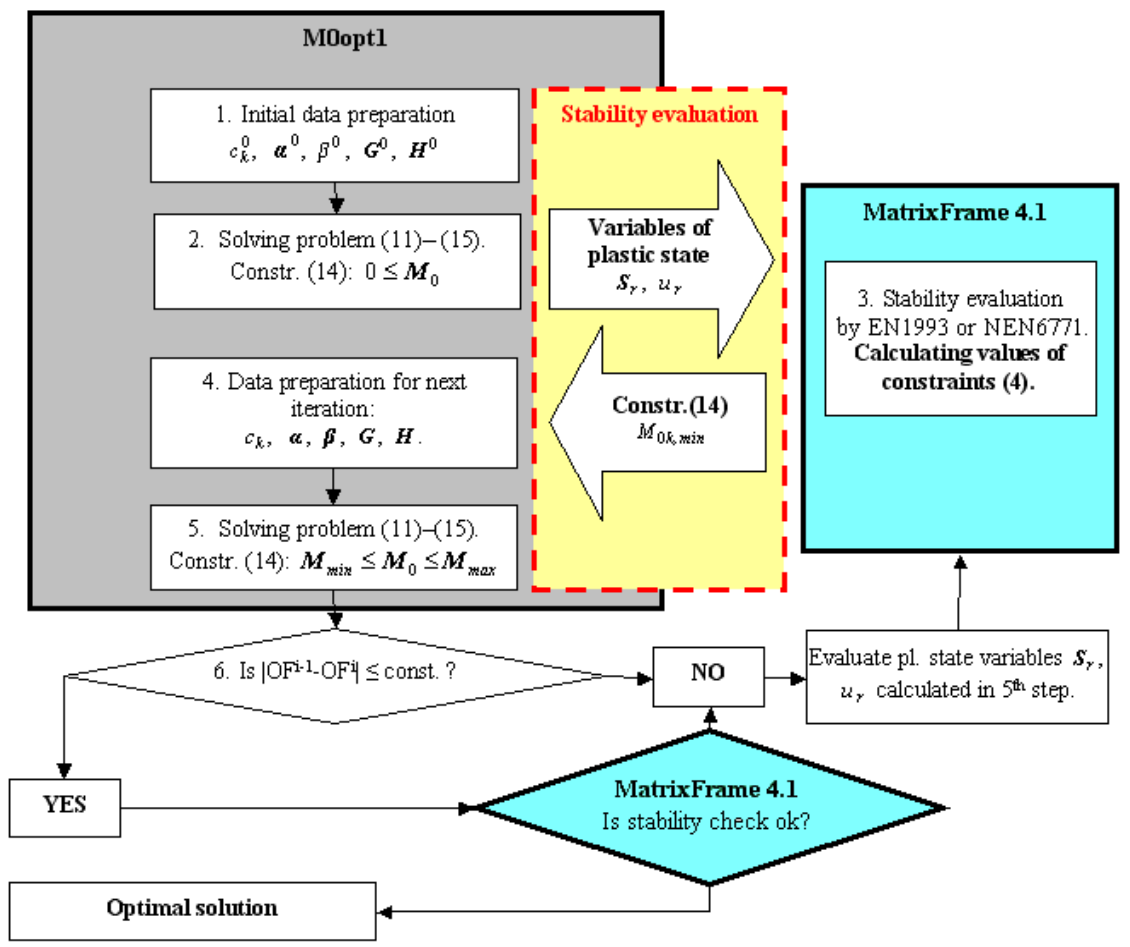

Fig. S1. Flowchart of the proposed solution algorithm for design problem 


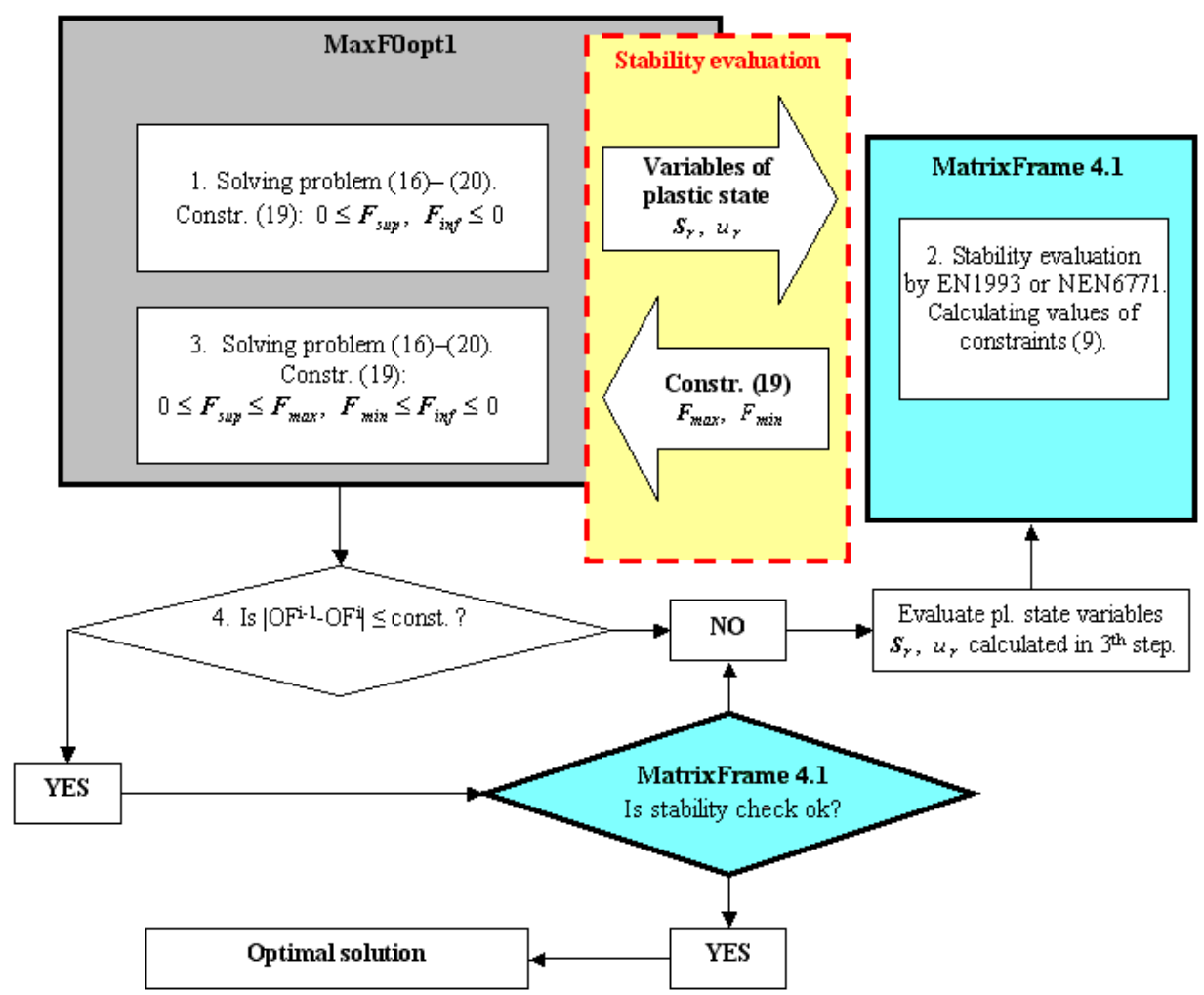

Fig. S2. Flowchart of the proposed solution algorithm for the checking problem

Introduction to examples. An Example 1 of the design problem (11)-(15) and Example 2 of the verification problem (16)-(20) illustrate the proposed calculation technique. The convex nonlinear optimization software modules M0opt1 and MaxFopt 1 were used for the first and second problems, respectively. They are developed by the authors and are based on the Rosen project-gradient method (Bazaraa et al. 2004) and are used here to obtain a solution of the numerical example under study. For stability evaluation, the MatrixFrame software for the building industry is used. Both examples are applied to a two-story frame (Fig. S3.). The frame is subjected to two sets of independent loads: the horizontal, concentrated forces $\boldsymbol{F}_{1}=\left\{F_{1}^{1}, F_{1}^{2}, F_{1}^{3}, F_{1}^{4}, F_{1}^{5}\right\}$ acting on the nodes of the frame, and the vertical, uniformly distributed forces $\boldsymbol{F}_{2}=\left\{F_{2}^{1}, F_{2}^{2}\right\}$ acting on the roof beams $(6,7,8,9)$. A permanent load $\boldsymbol{F}_{c}=117 \cdot \mathrm{kN} / \mathrm{m}$ acts on the floor beams $(10,11)$. The limits of load variations are defined by the inequalities $\boldsymbol{F}_{1, \text { inf }} \leq \boldsymbol{F}_{1} \leq \boldsymbol{F}_{1, \text { sup }}$, 
$\boldsymbol{F}_{2, \text { inf }} \leq \boldsymbol{F}_{2} \leq \boldsymbol{F}_{2, \text { sup }}$. The vector of inner forces of the discretized frame is $\boldsymbol{S}=(\boldsymbol{M}, \boldsymbol{N})^{T}$ $=\left(M_{1}, M_{2}, M_{3}, \ldots, M_{28}, N_{1}, N_{2}, \ldots, N_{11}\right)^{T}=\left(S_{z}\right)^{T}, z=1,2, \ldots, n=39$, i.e., when both bending moments $M$ and axial forces $N$ are taken into account. The frame is made of steel, with a modulus of elasticity $E=210 \mathrm{GPa}$ and a yield limit $\sigma_{y}=235 \mathrm{MPa}$.

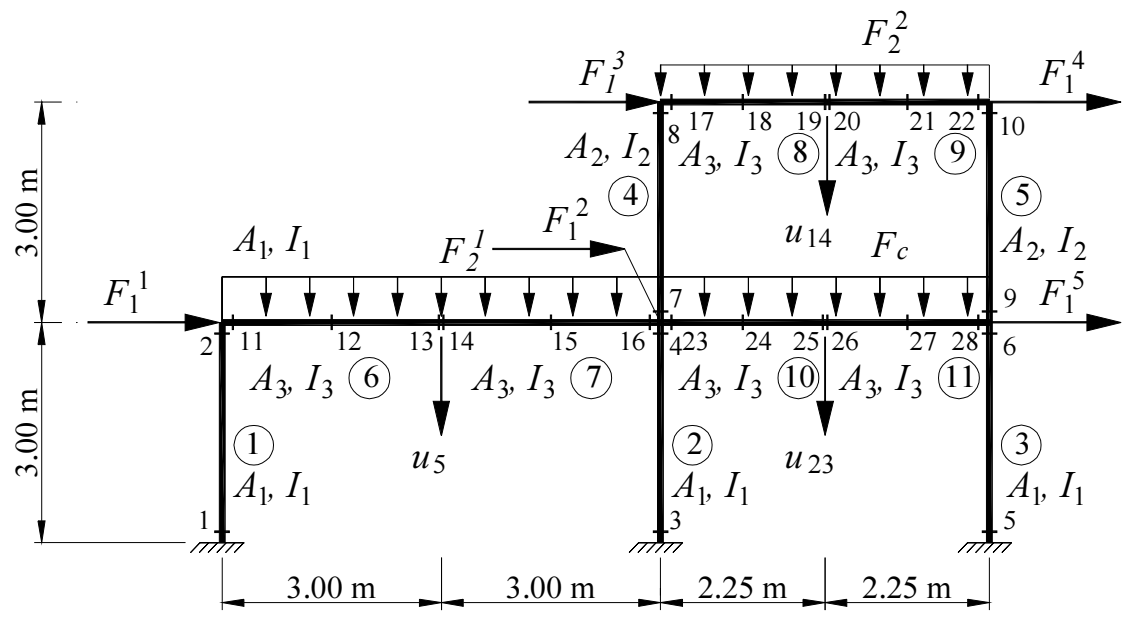

Fig. S3. Discretized frame

The material is elastic-perfectly plastic. The cross-sections of the frame columns, roof, and floor beams are shown in Fig. S4. The upper bound of total displacements constraints $\boldsymbol{u}_{\max }$ are chosen according to ratio $L_{k} / \delta_{\max }$ where $L_{k}$ is the length of the $k$ th element (beam), $\delta_{\max }$ is the value related to building type and is specified in national standards; in the paper $\delta_{\max }=200$ is assumed. The lower bound total displacements constraints $\boldsymbol{u}_{\text {min }}=-\infty$ (displacements aren't limited).
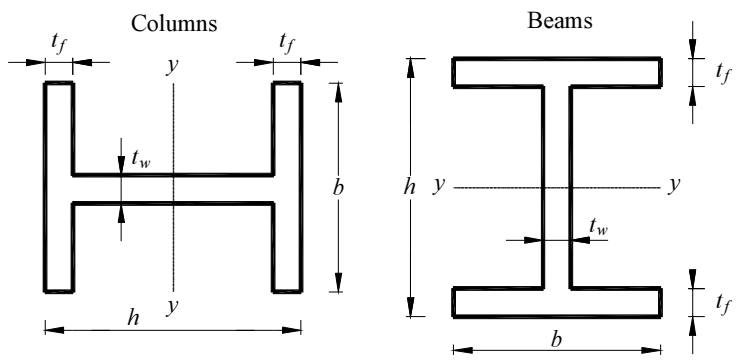

Fig. S4. Cross-sectional shapes for frame columns and beams 
Example 1. The plastic moments minimization problem (11)-(15) with stability constraints calculated according to the EN1993 standard is investigated in this example. The limits of load variations are $\boldsymbol{F}_{1, \text { inf }}=\{-9,75,-4,9,-5,-6,75,-19,5\} \mathrm{kN}$, $\boldsymbol{F}_{1, \text { sup }}=\{13,6,5,6,75,5,14,6\} \mathrm{kN}, \boldsymbol{F}_{2, \text { inf }}=\{0,0\}, \boldsymbol{F}_{2, \text { sup }}=\{48,48\} \mathrm{kN} / \mathrm{m}$. The parameters $b$ and $h$ remain the same throughout the optimization process, with only the thickness $t=t_{f}=t_{w}$ of the flanges and web varying. In the case of discrete optimization, the cross-sections are selected from an assortment of available manufactured crosssections. The main task is to determine the minimal plastic moments of the affected frame (Fig. S3.). The frame plastic moments minimization is performed using mathematical model (11)-(15). The unknowns are plastic moments $\boldsymbol{M}_{0}$, and the vector of plasticity multipliers, $\lambda_{j}, j=1,2, \ldots, 4$. Five calculation cases were investigated:

Case C1. Only strength constraints (12) are taken into account. Optimization is continuous;

Case C2. Only strength (12) and stiffness (15) constraints are evaluated. The following total displacement constraints are imposed: $-\infty \leq u_{5} \leq 0,03 \mathrm{~m}$, $-\infty \leq u_{14} \leq 0,0225 \mathrm{~m},-\infty \leq u_{23} \leq 0,0225 \mathrm{~m}$. Optimization is continuous;

Case C3. Only strength (12) and structural constraints (14) are taken into account. Optimization is continuous;

Case C4. Only strength (12) and structural constraints (14) are taken into account. Optimization is discrete;

Case C5. All constraints (strength (12), stiffness (15), and structural (stability) (14)) are evaluated. The following total displacement constraints are imposed: $-\infty \leq u_{5} \leq 0,03 \mathrm{~m},-\infty \leq u_{14} \leq 0,0225 \mathrm{~m},-\infty \leq u_{23} \leq 0,0225 \mathrm{~m}$. Optimization is continuous.

The calculation cases $\mathrm{C} 1$ and $\mathrm{C} 2$ was solved using the software M0opt1, whereas for the cases C3 - C5 the software coupling M0opt1-MatrixFrame, using the sequence of operations described in Fig. S1., was used.

The calculated results for all the cases described within the imposed constraints are shown in Table S4 and Fig. S5.

Table S4. Calculated results for the design problem

\begin{tabular}{|c|c|c|c|c|c|c|}
\hline Case & $M_{01}, \mathrm{Nm}$ & $M_{02}, \mathrm{Nm}$ & $M_{03}, \mathrm{Nm}$ & $\begin{array}{c}\text { Objective } \\
\text { function (OF) }\end{array}$ & $\begin{array}{c}\text { Volume, } \\
\mathrm{m}^{3}\end{array}$ & $\begin{array}{c}\text { Location of } \\
\text { the plastic strains }\end{array}$ \\
\hline $\mathrm{C} 1$ & 75441 & 41673 & 204168 & 3991522 & 0,26149777 & $6,2,23$ \\
\hline $\mathrm{C} 2$ & 93970 & 34942 & 223206 & 4403462 & 0,292369813 & 23 \\
\hline C3 & 120537 & 48302 & 186579 & 4173339 & 0,283231289 & 23 \\
\hline C4 & 174986 & 57610 & 189018 & 4755802 & 0,350856685 & 23 \\
\hline C5 & 108090 & 44151 & 215258 & 4466587 & 0,300776204 & 23 \\
\hline
\end{tabular}


In cases $\mathrm{C} 2$ and $\mathrm{C} 5$, the total displacement $u_{23}$ reaches the upper bound $u_{\max }=0,0225 \mathrm{~m}$. When discrete optimization is used in case $\mathrm{C} 4$, the limit moments $M_{01}=174986 \mathrm{Nm}, M_{02}=57610 \mathrm{Nm}$, and $M_{03}=189018 \mathrm{Nm}$ correspond to crosssections HE240, HE160, and IPE330 respectively.

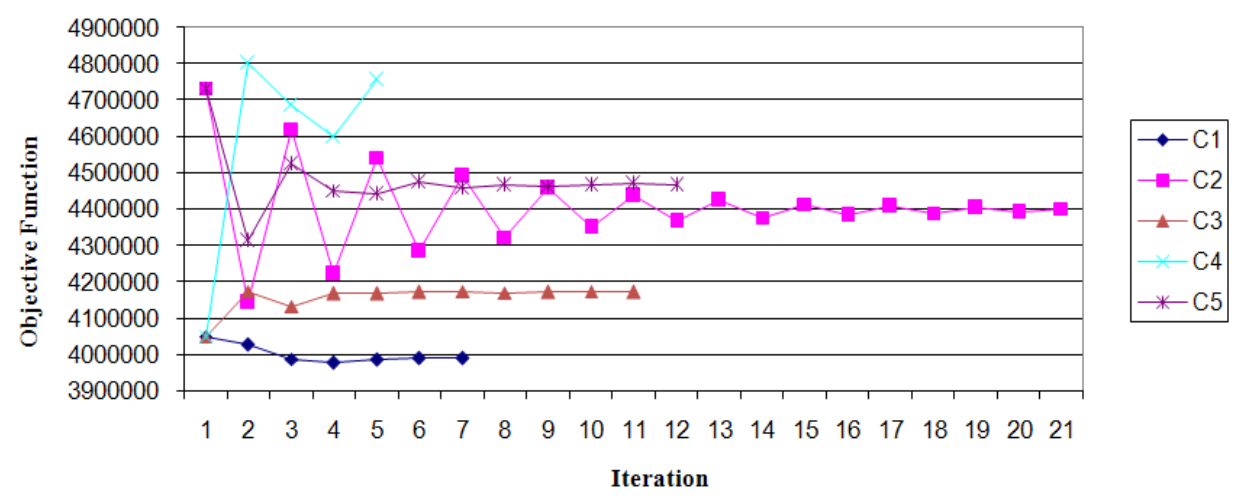

Fig. S5. Convergence of the optimization-problem objective function

It is noteworthy, that the same discrete cross-sections were obtained in $4^{\text {th }}$ and $5^{\text {th }}$ iterations, and therefore the optimization process was stopped and assumed that optimal solution was reached. The discrete optimization (case C4) is very important for civil engineering, however the continuous optimization (cases C1-C3, C5) could be an introductory step to discrete optimization . For example, using section properties, obtained from the continuous optimization, is possible to choose nearest fitting discrete crosssection from assortment. Convergence of the main optimization-problem objective function within the desired accuracy is a criterion of the optimal solution.

Example 2. The checking problem (16)-(20) with stability constraints calculated according to the NEN 6771 standard is analyzed in this example.

The values of the cross-sections are shown in Table S5. The cross-sections remain unchanged throughout the entire optimization process. Limits for load variations $\boldsymbol{F}_{1, \text { inf }} \leq \boldsymbol{F}_{1} \leq \boldsymbol{F}_{1, \text { sup }}, \quad \boldsymbol{F}_{2 \text {,inf }} \leq \boldsymbol{F}_{2} \leq \boldsymbol{F}_{2, \text { sup }}$ are unknowns of the optimization problem. The loads $\boldsymbol{F}_{1}$ and $\boldsymbol{F}_{2}$ represents the wind and snow loads, respectively. The snow load can't act from bottom to top, so the constraint $\boldsymbol{F}_{2, \min }=-10 \leq \boldsymbol{F}_{2, \text { inf }} \leq 0$ was applied for load $\boldsymbol{F}_{2}$ variation bound $\boldsymbol{F}_{2, \text { inf }}$. The main task is to determine the load-variation bounds of the affected frame (Fig. S3.). The frame load optimization is performed using mathematical model (16)-(20). The unknowns are the load-variation bounds, $\boldsymbol{F}_{1, \text { inf }}, \boldsymbol{F}_{2, \text { inf }}, \boldsymbol{F}_{1, \text { sup }}$, and $\boldsymbol{F}_{2, \text { sup }}$, and the vector of plasticity multipliers, $\lambda_{j}, j=1,2, \ldots, 4$. 
Table S5. Values of cross-sections

\begin{tabular}{|c|c|c|c|c|c|c|}
\hline $\begin{array}{c}\text { Elements } \\
k=1,2, \ldots, s\end{array}$ & $\begin{array}{c}b, \\
\mathrm{~m}\end{array}$ & $\begin{array}{c}h, \\
\mathrm{~m}\end{array}$ & $\begin{array}{c}t, \\
\mathrm{~m}\end{array}$ & $\begin{array}{c}A_{k}, \\
\mathrm{~m}^{2}\end{array}$ & $\begin{array}{c}M_{0 k}, \\
\mathrm{Nm}\end{array}$ & $\begin{array}{c}N_{0 k}, \\
\mathrm{~N}\end{array}$ \\
\hline $1,2,3$ & 0,15 & 0,15 & 0,016 & 0,006688 & 88665 & 1571680 \\
\hline 4,5 & 0,1 & 0,12 & 0,01 & 0,003000 & 31725 & 705000 \\
\hline $6,7,8,9,10,11$ & 0,15 & 0,2 & 0,03 & 0,013200 & 21432 & 3102000 \\
\hline
\end{tabular}

Three calculation cases were investigated:

Case C1. Only strength constraints (17) are taken into account;

Case C2. Strength (17) and stiffness (20) constraints are taken into account. The following total displacement constraints are imposed: $-\infty \leq u_{5} \leq 0,03 \mathrm{~m}$, $-\infty \leq u_{14} \leq 0,0225 \mathrm{~m},-\infty \leq u_{23} \leq 0,0225 \mathrm{~m}$;

Case C3. Strength (17) and structural constraints (19) are taken into account.

The calculation cases C1 and C2 was solved using the software MaxFopt1, whereas for the cases C3 the software coupling M0opt1 - MatrixFrame, using the sequence of operations described in Fig. S2., was used.

The calculated results for all cases described within the imposed constraints are presented in Table $\mathrm{S} 6$. In case $\mathrm{C} 2$, the total displacement $u_{23}$ reaches the upper bound $u_{\max }=0.0225 \mathrm{~m}$. In presented example the stability evaluation plays important role.

Table S6. Calculated results for the checking problem

\begin{tabular}{|c|c|c|c|c|c|c|}
\hline Case & $\begin{array}{c}\boldsymbol{F}_{1, \text { sup }}, \\
\mathrm{N}\end{array}$ & $\begin{array}{c}\boldsymbol{F}_{2, \text { sup }}, \\
\mathrm{N} / \mathrm{m}\end{array}$ & $\begin{array}{c}\boldsymbol{F}_{1, \text { inf }}, \\
\mathrm{N}\end{array}$ & $\begin{array}{c}\boldsymbol{F}_{2, \text { inf }}, \\
\mathrm{N} / \mathrm{m}\end{array}$ & OF & $\begin{array}{c}\text { Location of the } \\
\text { plastic strains }\end{array}$ \\
\hline $\mathrm{C} 1$ & 23679 & 44035 & -29349 & -10 & 97073 & $4,6,8,23$ \\
\hline $\mathrm{C} 2$ & 15777 & 26006 & -23958 & -10 & 65751 & 4,6 \\
\hline $\mathrm{C} 3$ & 11839 & 19200 & -14673 & -10 & 45722 & 4 \\
\hline
\end{tabular}

In case $\mathrm{C} 3$ the value of objective function (OF) is the smallest. The difference of OF value between $\mathrm{C} 3$ and $\mathrm{C} 2$ is $44 \%$ and between $\mathrm{C} 3$ and $\mathrm{C} 1$ is $112 \%$. The iterative solution procedure was performed only for case $\mathrm{C} 3$, while the optimal solutions for cases $\mathrm{C} 1$ and $\mathrm{C} 2$ were obtained in the first iteration. Only one iteration was needed because no software coupling was used and the stiffness matrix $\boldsymbol{K}$ is constant in the whole optimization process.

Conclusions:

1. Practical implementation of a shakedown structural-design methodology should be based, not only on theoretical improvements and new mathematical models, but also on a close relation with existing building design practices. In this way, it is possible to avoid a gap between the theoretical methods of structural optimization and real design practices based on standards. 
2. The part of the solution related to stability of main optimization problems with strength, stiffness, and stability constraints, is transferred to a design software package which conforms to implemented standards.

3. The solution procedure therefore becomes iterative.

4. The initial data for the design software become residual forces and residual displacements obtained from the solution of the optimization problem, i.e., the influence of plastic deformations is evaluated.

5. The proposed ways of solving optimization problems include the implementation of discrete-optimization principles. In this way, shakedown theory can become a generalized tool for calculation and optimization of elastic-plastic structures under different loading conditions.

6. The monotonically increasing load, moving load and load combinations relevant to civil engineering can be interpreted as separate case of repeated variable load.

\section{Created Software}

This chapter reviews the software modules M0opt1 and MaxFopt1 solving the nonlinear optimization problems of shakedown structures. The description of Rosen project gradient method is provided. Also the mathematical models with constants, controlling optimization process and convergence, are presented. The initial data preparation is described and the technique of constant selection is proposed. In the chapter concluded:

1. In-house software allows full control over optimization process that is not possible to do with "black box" commercial software.

2. Optimization process and obtained results highly depends on chosen constants.

\section{Load Optimization of Elastic-plastic Axisymmetric Plates at Shakedown}

An elastic-plastic axisymmetric steel bending plate subjected to a repeated variable load is considered in the chapter. A new algorithm for the load optimization problem combining von Mises and Tresca yield criterion based on the Rosen project gradient method is proposed. The residual displacement and residual moments influence matrixes and, and in the case of Tresca plasticity conditions, do not depend on internal forces. This feature has an important significance for the creation of the mathematical models for the load optimization problem: initially, the Tresca yield condition is applied and only in the latest step is the Mises plasticity criterion applied (Fig. S6.). 


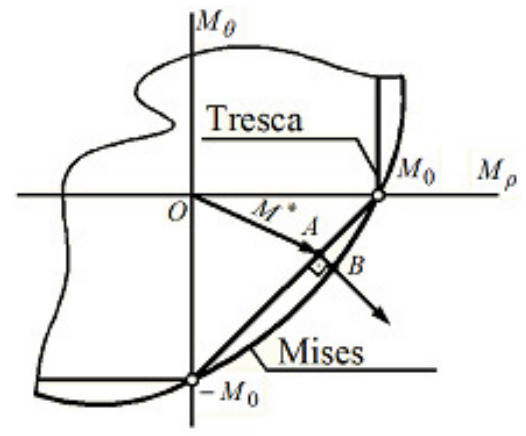

Fig. S6. The fragment of the switch from Tresca plasticity conditions to Mises plasticity conditions

Conclusions:

1. The influence matrixes of residual moments and displacements do not depend on the residual moments.

2. In the case of Mises plasticity conditions, the influence matrixes should be formulated using the gradients of plasticity conditions, which themselves depend on residual moments. The main load optimization problem, in the case of Mises, becomes practically not realizable, even with applied computer algebra methods.

3. One of the possible resolutions of the load optimization problem with a Mises plasticity condition is the application of an analogous problem solution obtained with Tresca plasticity conditions.

\section{General Conclusions}

1. Research show that elastic-plastic structure subjected by repeated variable load always will shakedown if nonlinear convex mathematical programming analysis problem have initial admisible point.

2. The load combinations, moving load and monotonically increasing load can be expressed in terms of repeated variable load.

3. Applying the created optimization problem solution methods it is possible to achieve very important for civil engineering practice discrete optimization; using section properties, obtained from the continuous optimization, is possible to choose nearest fitting discrete cross-section from assortment

4. Applying the created integrated iterative design methodology it is possible to optimise civil shakedown structures with strength, stiffness and stability (EN1993, NEN6771) constraints. In case of compression with bending the plastic deformation are evaluated too. Such improvements of optimization algorithms allow more precise design of structures. 
5. When the stability calculation tasks are transferred to the commercial software MatrixFrame 4.1 (or similar software with implemented design standards) it is possible to focus on development of optimization algorithm rather than to concentrate to implementation of complex stability calculations (that already available in existing software). Applying created integrated iterative design methodology it is possible to incorporate variables of plastic state into commercial software i.e. the cyclic loading is evaluated (no needed to consider the separate loading history). Currently available commercial software lacks such feature. Commonly, the only particular loading history is considered in commercial software. It is possible to evaluate several loading histories and then create the envelope. But the sum of actions is not equal to repeated variable load; because the plastic zones (hinges) developed from one loading history should affect results of other loading histories, but this is not the case in commercial software. The proposed optimization methodology does not have such drawback.

6. The complexity of optimization problems grows linearly with the finite elements used in discretized model number; while the load variation bound count $p=2^{m}$ influence exponential growth. With the current power of personal computers it is possible to optimise structures subjected by 32 load combinations $(\mathrm{m}=4)$ 


\section{Priedai $^{1}$}

A priedas. M0opt1 programos gradientų skaičiavimo paprogramès

A1. Tikslo funkcijos skaičiavimo paprogramė

A2. Tikslo funkcijos gradiento skaičiavimo paprogramè

A3. Apribojimų ir jų gradientų skaičiavimo paprogramė

B priedas. MaxFopt 1 programos gradientų skaičiavimo paprogramės

B1. Tikslo funkcijos skaičiavimo paprogramè

B2. Tikslo funkcijos gradiento skaičiavimo paprogramè

B3. Apribojimų ir jų gradientų skaičiavimo paprogramé

C priedas. Publikacijų bendraautorių sutikimai teikti publikacijas disertacijos gynimui

D priedas. Autoriaus publikacijų disertacijos tema kopijos

${ }^{1}$ Priedai pateikti pridètoje elektroninèje laikmenoje 


\section{Artūras VENSKUS}

PRISITAIKANČIU KONSTRUKCIJŲ OPTIMIZAVIMAS.

SĄSAJOS SU PROJEKTAVIMO STANDARTAIS

Daktaro disertacija

Technologijos mokslai, statybos inžinerija (02T)

OPTIMIZATION OF SHAKEDOWN STRUCTURES

IN THE CONTEXT OF STANDARDS

Doctoral Dissertation

Technological Sciences,

Civil Engineering (02T)

201105 05. 10,75 sp. I. Tiražas 20 egz.

Vilniaus Gedimino technikos universiteto

leidykla „Technika“,

Saulètekio al. 11, 10223 Vilnius,

http://leidykla.vgtu.lt

Spausdino UAB "Ciklonas",

J. Jasinskio g. 15, 01111 Vilnius 